LEONARDO GRANADA MIDEA

\title{
ANÁLISE ECONÔMICA FINANCEIRA COMPARATIVA DA AUTOPRODUÇÃO DIRETA OU CONECTADA NO SIN - UM ESTUDO DE CASO
}

Dissertação apresentada à Escola Politécnica da Universidade de São Paulo para obtenção do Título de Mestre em Engenharia.

SÃO PAULO

2009 
Este exemplar foi revisado e alterado em relação à versão original, sob responsabilidade única do autor e com a anuência de seu orientador.

São Paulo, 17 de junho de 2009.

Assinatura do autor

Assinatura do orientador

FICHA CATALOGRÁFICA

Midea, Leonaro Granada

Análise econômica financeira comparativa da autoprodução direta ou conectada no SIN - um estudo de caso / L.G. Midea. -ed.rev. -- São Paulo, 2009.

$107 \mathrm{p}$.

Dissertação (Mestrado) - Escola Politécnica da Universidade de São Paulo. Departamento de Engenharia de Energia e Automação Elétricas.

1. Hidroeletricidade (Produção) I. Universidade de São Paulo. Escola Politécnica. Departamento de Engenharia de Energia e Automação Elétricas II. t. 


\title{
ANÁLISE ECONÔMICA FINANCEIRA COMPARATIVA DA AUTOPRODUÇÃO DIRETA OU CONECTADA NO SIN - UM ESTUDO DE CASO
}

\author{
Dissertação apresentada à Escola \\ Politécnica da Universidade de São Paulo \\ para obtenção do Título de Mestre em \\ Engenharia.
}

Área de Concentração:

Sistemas de Potência

Orientador:

Prof. Dr. Luiz Claudio Ribeiro Galvão

SÃO PAULO

2009 


\section{AGRADECIMENTOS}

Ao meu orientador Luiz Claudio Ribeiro Galvão, pelo apoio para a realização deste trabalho.

Ao Fernando Amaral de Almeida Prado Júnior, tutor e amigo que teve fundamental participação neste trabalho e que muito tenho a agradecer.

A minha mãe Solange, e meus irmãos, Rodolfo e Giuseppe. Família que me ajuda diariamente.

A todos os meus outros familiares, que por muitos anos ainda me darão força.

Ao meu pai Giuseppe (in memoriam), que certamente está me ajudando de um bom lugar.

A minha esposa Marcella, pelo amor, paciência e apoio no decorrer deste trabalho.

Aos meus queridos amigos da CBA e Votorantim e todos os demais.

Aos colaboradores da Secretaria de Pós-Graduação da Engenharia Elétrica.

Enfim, a todos aqueles que contribuíram de forma direta ou indireta na realização deste feito. 


\section{RESUMO}

Midea, Leonardo Granada; Análise econômica financeira comparativa da autoprodução direta ou conectada no SIN - um estudo de caso/L.G. Midea. -- São Paulo, 2009. p. Dissertação (Mestrado) - Escola Politécnica da Universidade de São Paulo. Departamento de Engenharia de Energia e Auto-mação Elétricas. 1. Hidroeletricidade (Produção) I. Universidade de São Paulo. Escola Politécnica. Departamento de Engenharia de Energia e Automação Elétricas II. t.

Este trabalho tem como objetivo principal verificar a viabilidade econômica financeira da autoprodução direta e interligada, isto é, elaborar uma comparação entre uma usina hidrelétrica ligada diretamente à unidade de consumo, e uma usina ligada ao Sistema Interligado Nacional, com potência e energia asseguradas. Para isso, foram utilizados, como premissas, uma indústria de alumínio que, como parte integrante dos grandes consumidores de energia brasileira, é um tipo de indústria eletro-intensiva, e emprega milhares de pessoas direta e indiretamente; também uma usina hidrelétrica, que neste trabalho foi a UHE Piraju, usina de concessão da CIA BRASILEIRA DE ALUMíNIO, que gentilmente cedeu os dados de geração física real. Foram adotadas as seguintes metodologias para comparação da viabilidade, utilizando um cenário de geração e preços SPOT dos anos de 2006 e 2007: (i) Autoprodução Direta: Geração física real, comercializando excedentes e comprando energia do mercado ao preço SPOT quando necessário, e considerando todos os encargos e benefícios deste tipo de ligação; (ii) Autoprodução Conectada no SIN: Energia Assegurada Sazonalizada em 3 cenários distintos, Flat, com sazonalização moderada e sazonalização otimizada, considerando também os custos de conexão e encargos pertinentes para cada cenário. Os resultados apresentados mostram que, por pouca margem de diferença, foi mais vantajoso o cenário com a energia assegurada otimizada, porém, é possível verificar que, ponderando os resultados apresentados nos diversos cenários, verificamos que é mais viável a usina ligada 
diretamente à carga, pois a previsibilidade do mercado de preços de curto prazo é pequena, e dificilmente se acertaria com precisão os PLD's registrados no ano seguinte ao da sazonalização. Contudo, o Decreto oㅜ 5.163, de 30 de Julho de 2004, através do Artigo 71, somente permite que usinas sejam ligadas diretamente à carga se estiverem dentro do mesmo sítio. O proposto é a inclusão de um novo parágrafo no Artigo $71 \mathrm{com}$ condições de economicidade para a permissão da ligação da usina diretamente ao consumo.

Palavras-chave: Autoprodução de Energia; Redução de Custos com Energia; Ligação da Usina à unidade de Consumo; Ligação da Usina no SIN. 


\begin{abstract}
Midea, Leonardo Granada; The comparative economic financial analysis of the direct self production or connected to "SIN" (National Interconnected System) - case analysis / L.G. Midea. -- São Paulo, 2009. p. Assay (Master Degree) - Escola Politécnica da Universidade de São Paulo. Energy Enginnering and Electric Automation Department. 1. Hydropower (Production) I. Universidade de São Paulo. Escola Politécnica. Energy Enginnering and Electric Automation Department II. t.
\end{abstract}

The main goal of this study is to verify the economic financial feasibility of the direct self production, it means, of a hydropower unit directly connected to a consumption unit and to a hydropower unit connected to the "SIN", with guaranteed power and energy. For this purpose, the study used as pattern an aluminum industry, which, as part of the Brazilian hall of the major energy users, a type of electric-intensive industry, and that involves thousands of employees directly and indirectly, as well as an hydroelectric power unit, which in this study was the UHE Piraju, the energy authorized supplier unit of the CIA BRASILEIRA DE ALUMÍNIO, who gently provided the real generation data. The following methodology were adopted to compare the feasibility, using a generation scenario and SPOT values of 2006 and 2007: (i) Direct Self Production: Real generation, trading leftovers and acquiring market energy at SPOT values, when required, and considering all costs and benefits of this type of connection; (ii) "SIN" Connected Self production: guaranteed seasoned energy in different scenarios, Flat, with seasonalization moderated and seasonalization optimized, also considering the connection and applicable costs for each scenario. The presented results indicated that, for a small difference, the most advantageous scenario was the one with optimized guaranteed energy, however, it is possible to verify that evaluating the presented results in the different cases, it was verified that is more feasible the unit directed connected to a demand, since the forecast of short term values market is small, and it would hardly precise ascertain with the registered "PLD" (Settlement Price 
for the Differences) in the following year of the seasonalization. However, the Act n. 5.163, July 30, 2004, through the Article 71 only allows power units to be connected to the demand if they are in the same site. The proposal is the inclusion of a new paragraph in the Article 71 with economic conditions in order to allow the connection between the power unit to the consumption.

Key words: Energy Self production; Energy Costs Reduction; Power Unit Connection to a Consumption unit; power unit connection to "SIN". 


\section{SUMÁRIO}

1. INTRODUÇÃO

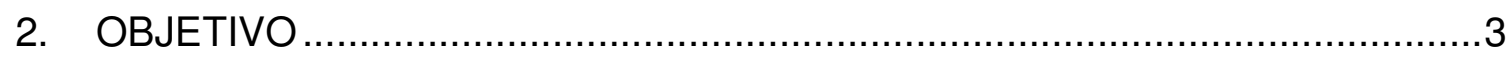

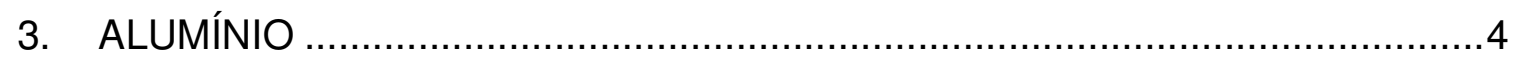

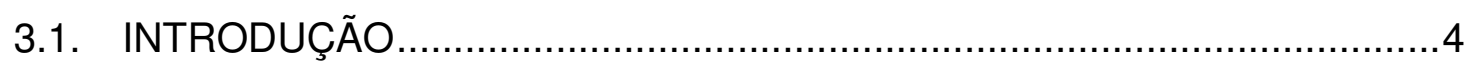

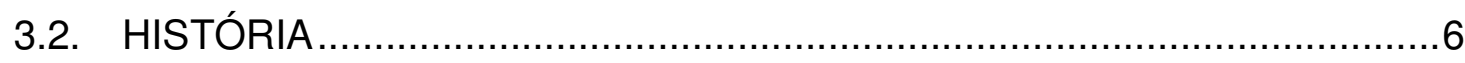

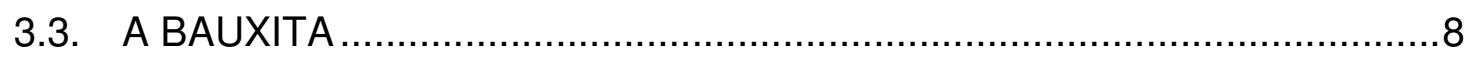

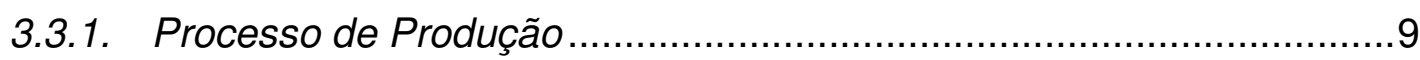

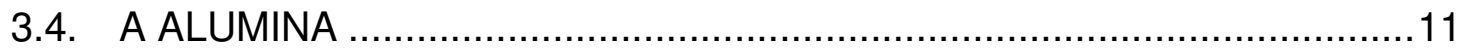

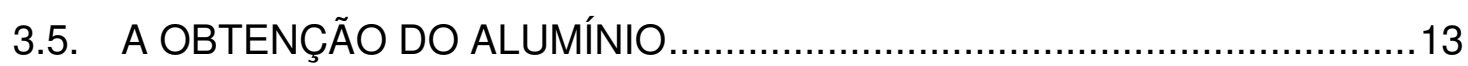

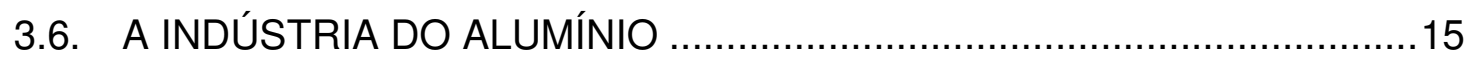

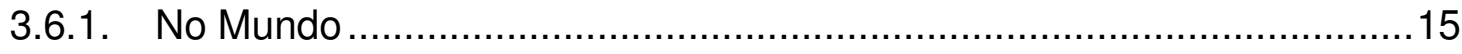

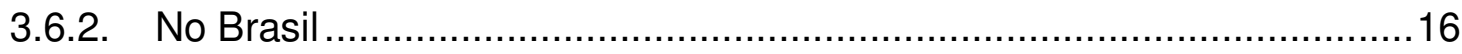

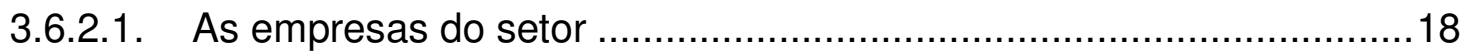

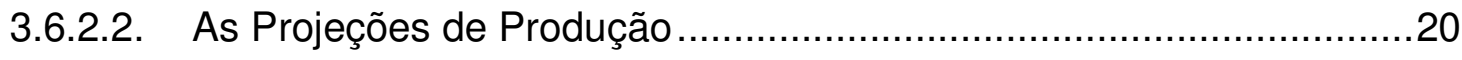

3.6.2.2.1. Alumínio Primário......................................................................20

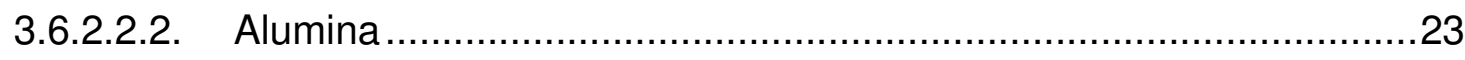

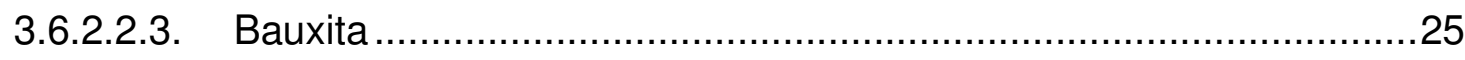

3.6.3. A Representatividade na Economia Brasileira...................................2

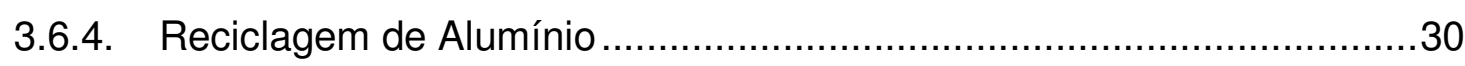

3.6.5. Energia Elétrica e Alumínio ..............................................................

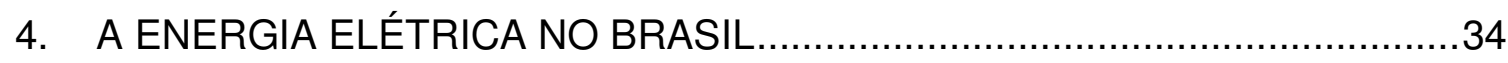

4.1.1. RISCOS NO SUPRIMENTO DE ENERGIA ELÉTRICA …...................34

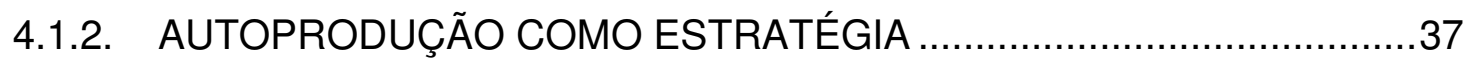

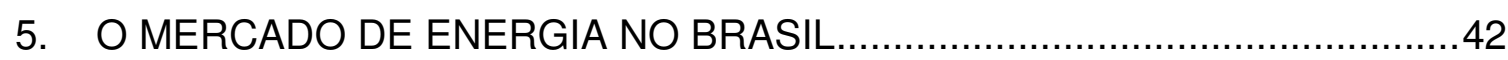

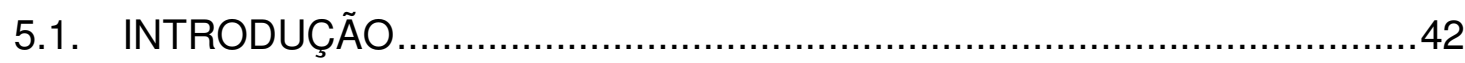

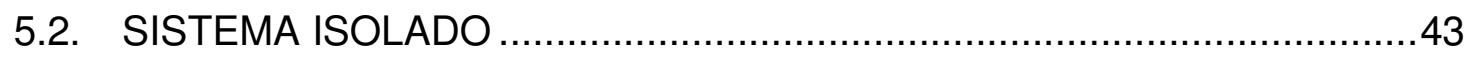

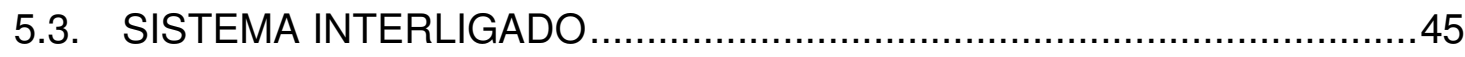

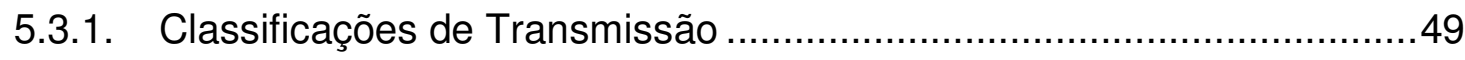


5.3.2. Tarifas de Transmissão e Encargos ............................................50

5.3.2.1. Tarifa de Uso do Sistema de Transmissão .......................................50

5.3.2.2. Programa de Incentivo às Fontes Alternativas de Energia Elétrica....51

5.3.2.3. Conta de Desenvolvimento Energético ...........................................53

5.3.2.4. Conta de Consumo de Combustíveis Fósseis ..................................54

5.3.2.5. Taxa de Fiscalização de Serviços de Energia Elétrica.......................55

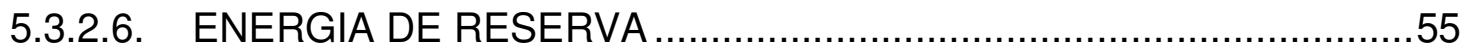

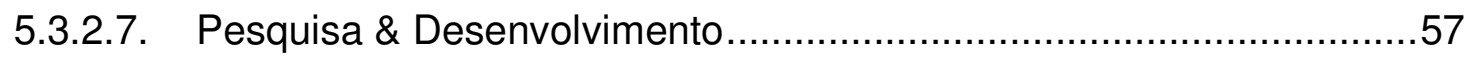

5.4. CÂMARA DE COMERCIALIZAÇÃO DE ENERGIA ELÉTRICA ...............58

5.4.1.1. PLD - Preço de Liquidação das Diferenças....................................60

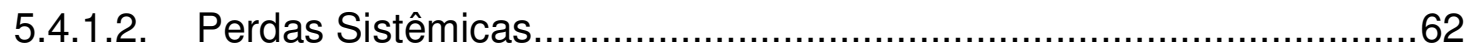

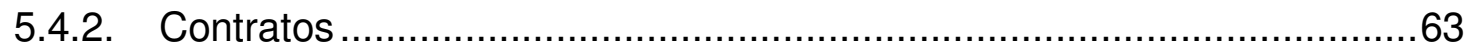

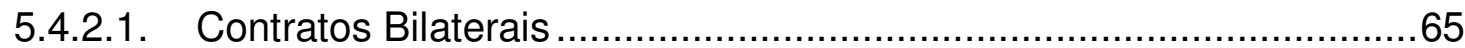

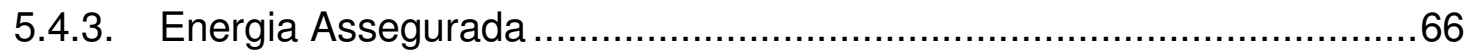

5.4.3.1. Sazonalização e Modulação da Energia Assegurada .......................67

5.4.3.2. Mecanismo de Realocação de Energia.............................................70

5.4.3.3. Encargos de Serviços do Sistema................................................... 73

5.4.3.3.1. Serviços Ancilares ........................................................ 74

5.4.4. Liquidação Financeira ............................................................ 76

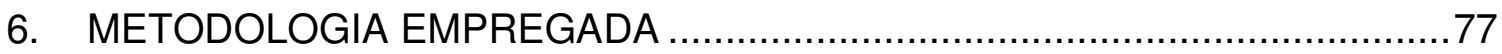

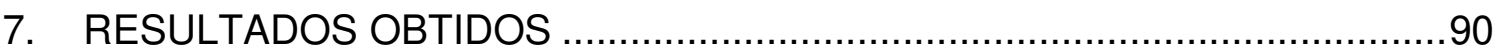

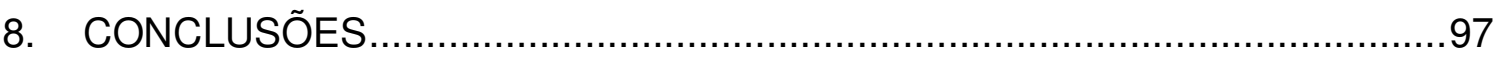

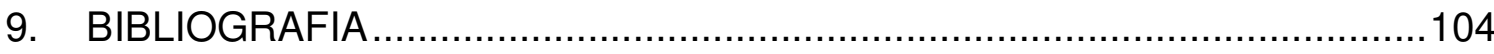




\section{INTRODUÇÃO}

O tema deste trabalho, Análise econômica financeira comparativa da Autoprodução Direta ou conectada no SIN - Uma visão crítica foi um desafio de verificar a viabilidade, diante das perspectivas de acréscimo da autoprodução de energia de grandes indústrias, principalmente eletrointensivas, na sua própria planta, visando garantir o suprimento e assegurar sua produção.

Esta dissertação foi também subsidiada pela publicação da apresentação da Empresa de Pesquisa Energética - EPE, que tem perspectivas de aumento da produção de energia elétrica "in sito".

O acréscimo de geração se dará, principalmente, através de cogeração ou termelétricas instaladas, ou até mesmo usinas hidrelétricas e eólicas, que podem ser uma estratégia para a indústria, principalmente a eletrointensiva, como a indústria de alumínio, em que o custo de energia elétrica é inversamente proporcional ao resultado líquido da empresa.

Um aspecto importante para a viabilidade das indústrias eletrointensivas e competitividade com relação ao mercado internacional, é o fato do Brasil ser privilegiado em fontes renováveis de energia.

Em um futuro de restrição de carbono, economias muito baseadas no carvão, como EUA e China, sofrerão um encarecimento do processo produtivo. Mas o Brasil, como sempre lembra o presidente, é a pátria dos biocombustíveis.

Com etanol, biodiesel e com ferro e aço produzido com carvão vegetal de floresta de eucalipto, o País ganha. Não precisa exportar o combustível, mas produzir o ferro e o aço aqui. O mesmo vale para o alumínio, na comparação com a produção australiana. O Brasil usa energia elétrica de origem hidráulica nesse processo de fabricação. A Austrália queima carvão mineral. A lógica dos EUA (para se opor à redução das emissões) é oposta à lógica do Brasil. Num mundo onde haja restrição de emissões, o País tem uma vantagem competitiva. Para ele, é bom economicamente se o mundo reduzir. Além, é claro, de evitar danos severos para a humanidade. (MEIRA FILHO, L. G. Mundo Negocia Pós-2012. [Depoimento a Giovana Girardi]. Jornal O Estado de São Paulo, São Paulo, 05 jun. 2008, p. X"'). 
Um dos desafios deste tema é a verificação da viabilidade econômica para a empresa, numa geração hidroelétrica localizada na planta da fábrica, com linhas de transmissão próprias, comparado com uma geração hidrelétrica conectada no Sistema Interligado Nacional (SIN). 


\section{OBJETIVO}

O objetivo deste trabalho é comparar, com base nas leis do mercado de energia elétrica nacional, uma fonte de energia hidrelétrica conectada diretamente na unidade de consumo, neste caso, uma indústria de alumínio, e esta mesma fonte conectada no Sistema Interligado Nacional.

Para o cálculo da viabilidade, serão utilizados todos os encargos de energia de uma usina hidrelétrica na modalidade de Produção Independente, com o propósito específico de autoprodução conectada no SIN, excetuando os encargos que uma usina conectada na carga também teria.

Também será utilizado o mercado de energia de curto prazo para comercialização de excedentes de energia que uma fonte de energia interligada no SIN tem, com base no histórico de preços do mercado de energia de curto prazo, utilizando todos os benefícios que possui esse tipo de usina.

Os impostos referentes à comercialização e utilização de energia, como PIS, COFINS e ICMS serão considerados quando pertinentes. 


\section{ALUMÍNIO}

\subsection{INTRODUÇÃO}

O alumínio é um metal que possui propriedades com diversos usos, sendo o terceiro elemento mais abundante na crosta terrestre.

É um metal jovem que apresenta grande aumento em sua demanda, mostrando sua importância para a indústria moderna. Sua produção atual já supera a totalidade de todos os outros metais não-ferrosos

Atualmente, existem diversas aplicações para esse material, em decorrência de suas vantagens sobre outros metais, principalmente por suas características físico-químicas, com destaque para seu baixo peso específico, sua resistência à corrosão e alta condutibilidade elétrica e térmica. Essas propriedades são as comumente requeridas para as matérias-primas da indústria que necessitam diversificar seus produtos e criar soluções para outros mercados, como o setor automotivo e de construção civil, por exemplo.

Hoje, China e Rússia são os maiores produtores mundiais de alumínio primário, porém, as maiores reservas de bauxita, que é a matéria-prima para a produção do alumínio primário, pertencem a Austrália e a Guiné, conforme podemos destacar na Tabela 1 a seguir.

\begin{tabular}{llll}
\multicolumn{1}{c}{ Reserva } & \multicolumn{3}{c}{ Produção } \\
\multicolumn{1}{c}{ Bauxita } & \multicolumn{1}{c}{ Bauxita } & \multicolumn{1}{c}{ Alumina } & \multicolumn{1}{c}{ Aluminio Primário } \\
$1^{\circ}$ Guiné & $1^{\circ}$ Austrália & $1^{\circ}$ Austrália & $1^{\circ}$ China \\
$2^{\circ}$ Austrália & $2^{\circ}$ Brasil & $2^{\circ}$ China & $2^{\circ}$ Russia \\
$3^{\circ}$ Brasil & $3^{\circ}$ Guiné & $3^{\circ}$ Estados Unidos & $3^{\circ}$ Canada \\
$4^{\circ}$ Jamaica & $4^{\circ}$ China & $4^{\circ}$ Brasil & $4^{\circ}$ Estados Unidos \\
& & $5^{\circ}$ Jamaica & $5^{\circ}$ Austrália \\
& & & $6^{\circ}$ Brasil \\
& & & $7^{\circ}$ Noruega
\end{tabular}

Tabela 1 - Ranking de Reserva e Produção Mundial (ABAL ${ }^{1}$, Anuário Estatístico 2006)

(1) ABAL - Associação Brasileira do Alumínio 
O Brasil tem a terceira maior reserva do minério no mundo, localizada na região amazônica, conforme podemos verificar na Tabela 1 anterior. Além da Amazônia, o alumínio pode ser encontrado no sudeste do Brasil, na região de Poços de Caldas e de Cataguases, ambas em Minas Gerais.

Apesar de possuir a terceira maior reserva de bauxita no mundo, o Brasil é apenas o 6을 maior produtor de alumínio primário.

A indústria de alumínio é um dos mais importantes setores industriais brasileiros, com faturamento anual de $\mathrm{R} \$ 12,1$ bilhões (Anuário Estatístico da $A B A L-2006)$. No item 3.6 encontra-se um relato mais detalhado sobre a indústria de Alumínio no Brasil e no Mundo.

Esse tipo de indústria é um dos maiores consumidores de energia do Brasil, sendo conhecida como Eletrointensiva, que por definição é aquele cujo valor da energia elétrica utilizada represente mais de $25 \%$ (vinte e cinco por cento) do custo da mercadoria produzida, assim entendida a soma do custo da matériaprima, material secundário e mão-de-obra, geralmente esse tipo de indústria tem seu fator de carga muito próxima a 1.

As indústrias eletrointensivas têm sempre uma grande preocupação com os aumentos de tarifas de energia elétrica que incidem diretamente nos custos do produto. O custo da energia elétrica corresponde a cerca de $30 \%$ do valor total do alumínio, sendo bastante elevado, considerando-se que esse percentual trata somente da matéria prima alumínio, não considerando outros valores agregados, como a transformação em chapas ou latas de refrigerantes, como exemplos. 


\subsection{HISTÓRIA}

A bauxita rocha que deu origem ao minério de alumínio, foi descoberta pelo francês P. Berthier, em 1821, na localidade de Les Baux, no sul da França. (MÁRTIRES, R. A. C., Balanço Mineral Brasileiro, 2001)

Em 1824, o físico dinamarquês Hans C. Dersted isola o alumínio em experiência de laboratório, no entanto, somente foi apresentado ao público, em uma feira em Paris, em meados de 1855.

O seu desconhecimento ao longo do tempo deve-se ao fato de que, ao contrário de outros elementos metálicos como o cobre e o ferro, o alumínio não ocorre naturalmente em sua forma metálica, tendo que ser obtido através de uma combinação com outros elementos, principalmente o oxigênio, o qual forma um óxido extremamente duro, conhecido como alumina.

O processo eletrolítico de obtenção do alumínio foi descoberto separadamente, em 1886, pelo francês Paul Heroult e pelo norte-americano Charles M. Hall, sendo esse processo denominado hoje como Hall-Heroult.

A partir de 1889, Friedrich Bayer inventa um processo de produção, em grande escala, da alumina a partir da bauxita, conhecido como processo Bayer. Essa operação se realiza na refinaria, onde o minério é transformado em alumina calcinada, a qual posteriormente será utilizada no processo eletrolítico. Através de uma reação química, a alumina é precipitada através do processo de cristalização por semente. O material cristalizado é lavado e seco através de aquecimento, para que o primeiro produto do processo de produção do alumínio, o óxido de alumínio de alta pureza, ou alumina, um pó branco e refinado, seja obtido.

A alumina produzida é o principal insumo para a produção do alumínio que, pelo processo de redução, é transformada em alumínio metálico.

Atualmente, para a obtenção do alumínio em escala industrial, a bauxita passa por um processo de moagem e, misturada a uma solução de soda cáustica, resulta em uma pasta que, aquecida sob pressão e recebendo uma nova adição 
de soda cáustica, dissolve-se, formando uma solução que passa por processos de sedimentação e filtragem, eliminando as impurezas.

A introdução do alumínio no Brasil se deu em 1913, com a transformação da matéria-prima importada em utensílios domésticos, sendo que a produção do primeiro lingote se deu em 1945. A partir de 1946, foi iniciado um projeto grandioso, abrangendo fábrica de alumina e de pasta Sodeberg, uma fundição para produção de ligas, extrusão, trefilação e manufatura de artefatos e fábrica de ácido sulfúrico e sulfato de alumínio. (Revista ALUMíNIO, edição I de 2007)

Para atender esse complexo, a Companhia Brasileira de Alumínio, a CBA, construiu sua primeira usina no rio Juquitiba, a Hidrelétrica França, possibilitando uma geração média de 155 GWh/ano, que teve a construção iniciada em 1954, e foi concluída em 1957.

O ano de 1947 é considerado um divisor de águas na história do alumínio no Brasil; com a decisão da Alcan de instalar unidades produtivas no País, com planos de crescimento acelerado, a Alcan adquire fábricas de utensílios domésticos e investe na construção de uma nova usina hidrelétrica.

Somente em 1963, foram descobertos platôs com grandes reservas de bauxita, com reservas de cerca de 500 milhões de toneladas de bauxita, quantidade cinco vezes superior aos recursos até então conhecidos, no município de Trombetas (PA), estimulando o interesse de investidores. Apesar disso, somente após 1984 a maior parte da produção atual de alumínio primário entra em operação, sendo impulsionada, mais ainda, a partir da década de 90, que é marcada pelo início da produção das latinhas de alumínio, e com o crescimento do ramo da reciclagem. 


\subsection{A BAUXITA}

A Bauxita é um minério que ocorre naturalmente, um material heterogêneo, composto principalmente de um ou mais hidróxidos de alumínio, e várias misturas de sílica, óxido de ferro, titania, alumino silicato, e outras impurezas em quantidades menores.

O nome bauxita é derivado do nome da aldeia Les Baux de Provence, na França meridional, onde foi descoberta em 1821 pelo geólogo Pierre Berthier.

Aproximadamente $85 \%$ da extração deste minério é utilizada como matériaprima para a fabricação da alumina, que, por sua vez, é empregada como matériaprima na fabricação do alumínio.

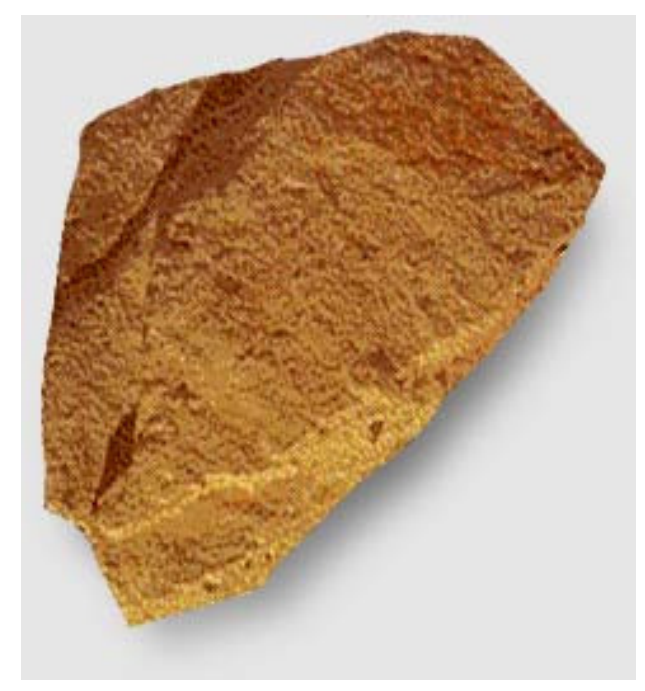

Figura 1 - Bauxita

Este minério pode ser encontrado principalmente em três grupos climáticos: o Mediterrâneo, o Tropical e o Subtropical. As principais reservas de bauxita, que perfazem um total de 55 a 75 bilhões de toneladas, são encontradas na América do Sul (33\%), África (27\%), Ásia (17\%) e Oceania (13\%), sendo que as três maiores localizam-se na Guiné $\left(1^{\mathrm{a}}\right)$, no Brasil $\left(2^{\mathrm{a}}\right)$ e na Austrália $\left(3^{\mathrm{a}}\right)$. Estima-se que as reservas totais devam ser suficientes para atender as demandas de alumínio no século XXI. (ABAL, Anuário Estatístico 2006)

A produção mundial de bauxita em 2004 foi de 157,4 milhões de toneladas, sendo os principais países produtores Austrália, Brasil, Guiné e Jamaica 
(CONSTANTINO, V.R.L., ARAKI, K., SILVA, D.O., OLIVEIRA, W. Preparação de compostos de alumínio a partir da bauxita: considerações sobre alguns aspectos envolvidos em um experimento didático. Quim. Nova, Vol. 25 (3), 490-498, 2002.).

Para ser economicamente viável, a extração de bauxita de uma jazida deve apresentar, no mínimo, 30\% de alumina aproveitável (ABAL $\left.{ }^{2}, 2007\right)$.

\subsubsection{Processo de Produção}

Muitos anos se passaram desde a sua descoberta, porém, o método de purificação da bauxita se manteve inalterado. Denominado Método Bayer, é utilizado para a manufatura de hidróxido e de óxido de alumínio. A Figura 2, a seguir, mostra um esquema simplificado desse processo.

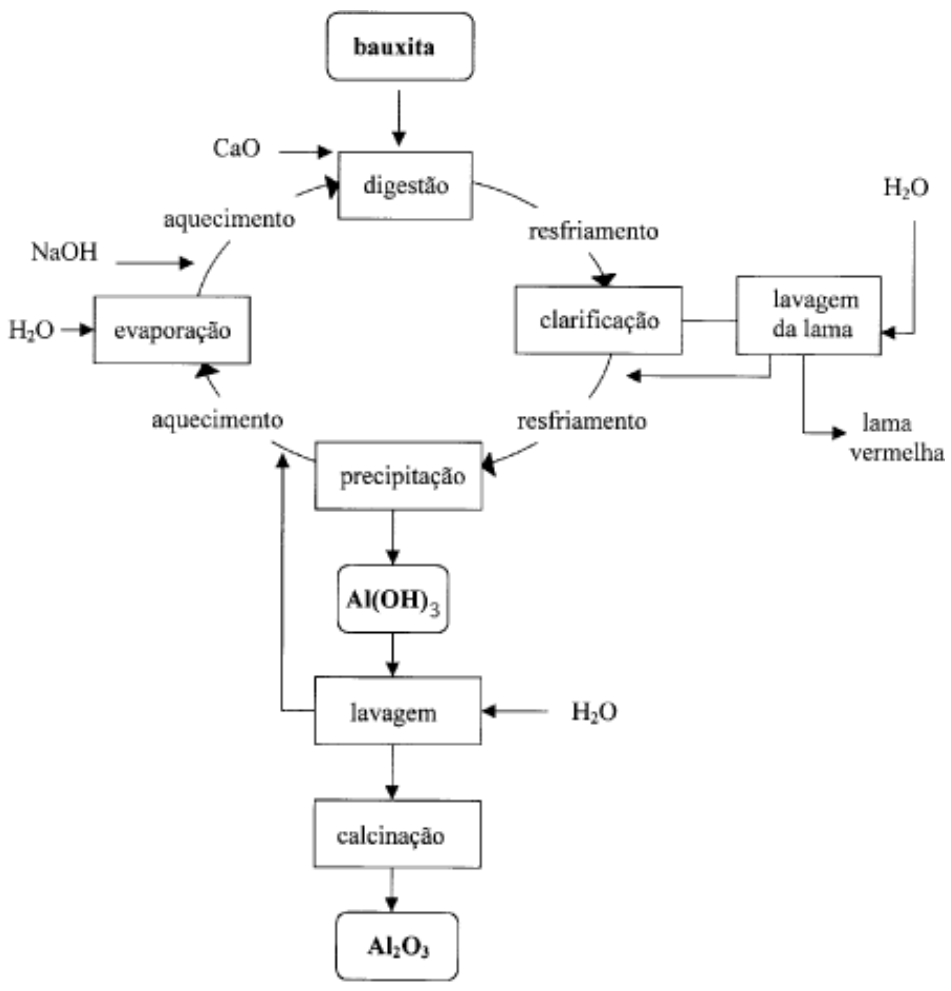

Figura 2 - Diagrama simplificado do processo Bayer

(2) http://www.abal.org.br; acesso em 20/05/2007 
Os processos físicos de produção de bauxita são simples, porém, exigem que sejam planejados para que não agridam o meio ambiente, e possam ser divididos em três etapas:

A primeira etapa corresponde à extração da bauxita, atualmente inteiramente mecanizada, e deve ser planejada, com recomposição do solo e vegetação, incluindo espécies nativas. A bauxita é encontrada entre 10 e $50 \mathrm{~cm}$ abaixo do solo, como mostra a figura 3 .

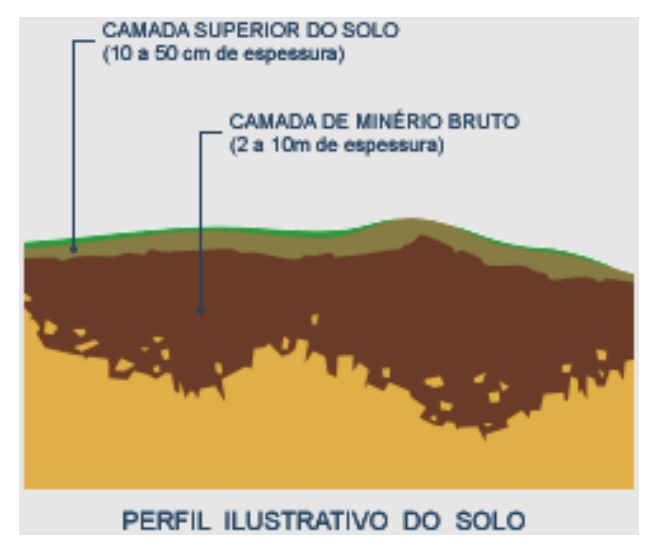

Figura 3 - Localização da Bauxita no Solo

A bauxita é extraída através de retro-escavadeiras, e transportada para o beneficiamento.

A segunda etapa é o beneficiamento, feito inicialmente na britagem, visando redução de tamanho, depois através da lavagem da bauxita bruta para se remover minerais de argila que são descartados como rejeito, e por fim, a secagem. Cerca de 70 a $75 \%$ da massa torna-se aproveitável. 


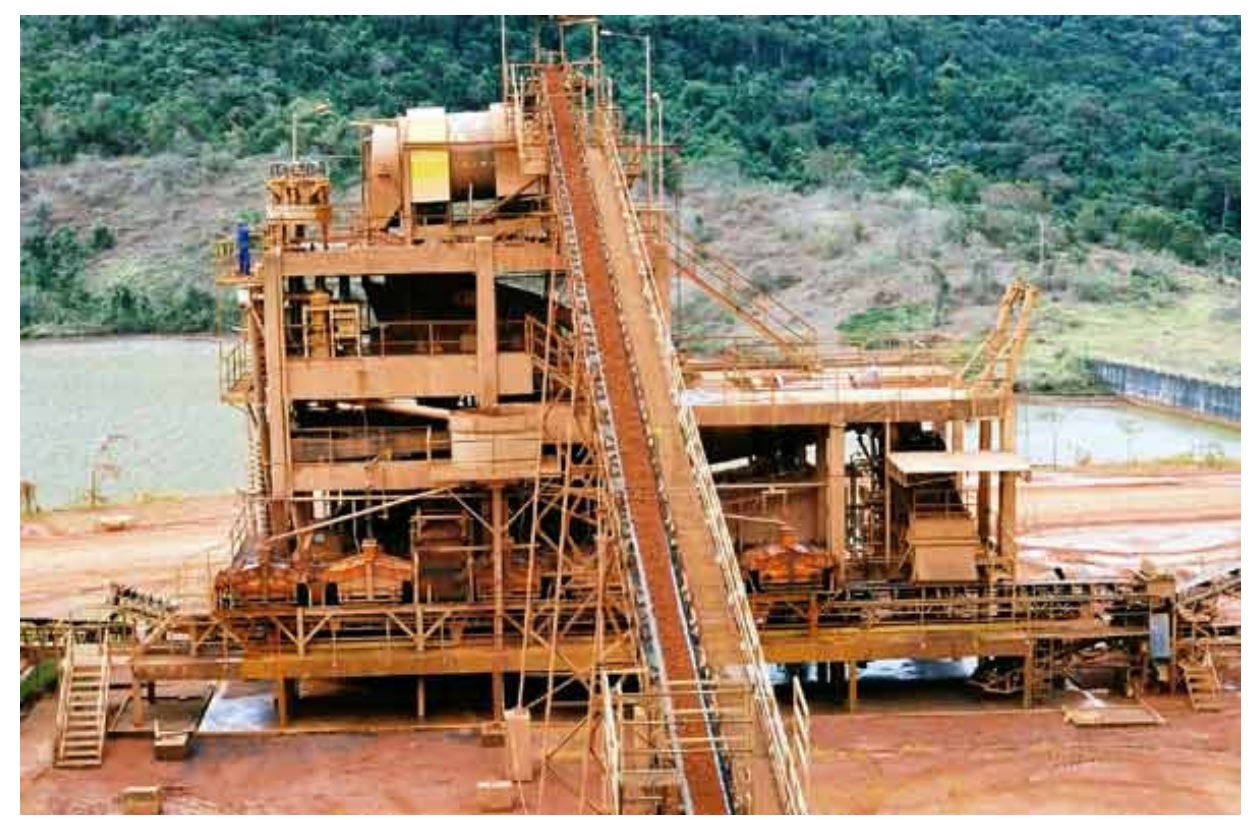

Figura 4 - Planta de Beneficiamento

A terceira etapa é a homogeneização, que permite a equalização das propriedades da bauxita.

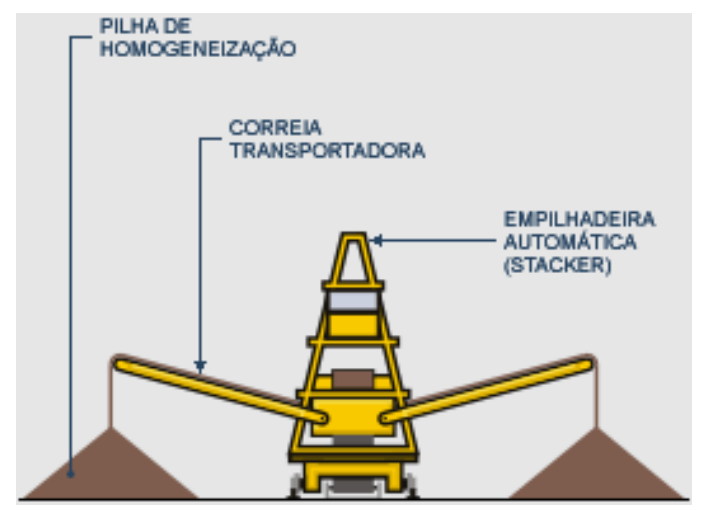

Figura 5 - Homogeneização

\subsection{A ALUMINA}

A obtenção da alumina é o segundo estágio até a transformação para o alumínio primário, para isso, a bauxita é trabalhada em moinhos onde é 
adicionada uma solução cáustica, cal e água. Após esse processo, a polpa é préaquecida e transferida aos digestores ou autoclaves, e é formado o licor de aluminato de sódio e impurezas, conforme demonstrado na figura 6 .

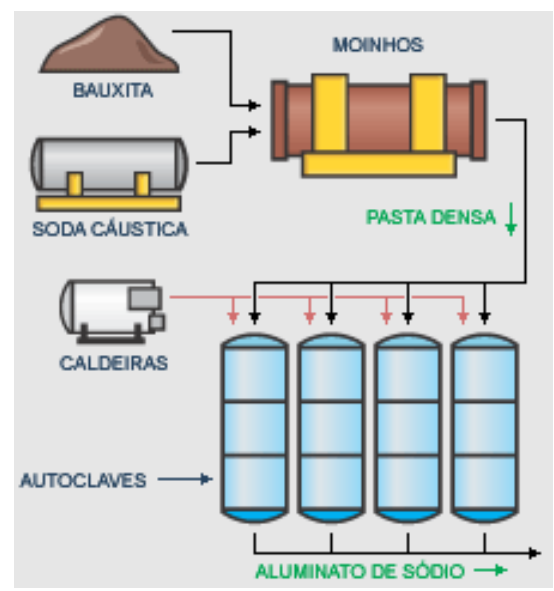

Figura 6 - Esquema de obtenção do Aluminato de Sódio

Após a obtenção do aluminato de sódio, este é transferido a espressadores que, com a mistura de agentes floculantes, formam uma pasta denominada "lama vermelha" que seriam os últimos resíduos da solução do aluminato de sódio. Esta lama, então, é lavada para o reaproveitamento de parte da soda. Esse processo é importante para a obtenção do hidróxido de alumínio, ou hidrato, de alta pureza.

Esta solução é resfriada e transferida para os precipitadores, onde é adicionada à semente, cristais finos de hidrato de alumina. A suspensão é mantida em agitação nos precipitadores por muitas horas. Depois, o hidrato produto é separado da semente por meio de classificação.

A solução, então, segue para fornos de calcinação, cuja temperatura é aproximadamente $1000^{\circ} \mathrm{C}$, onde é transformada em óxido de alumínio, mais conhecido por alumina. 


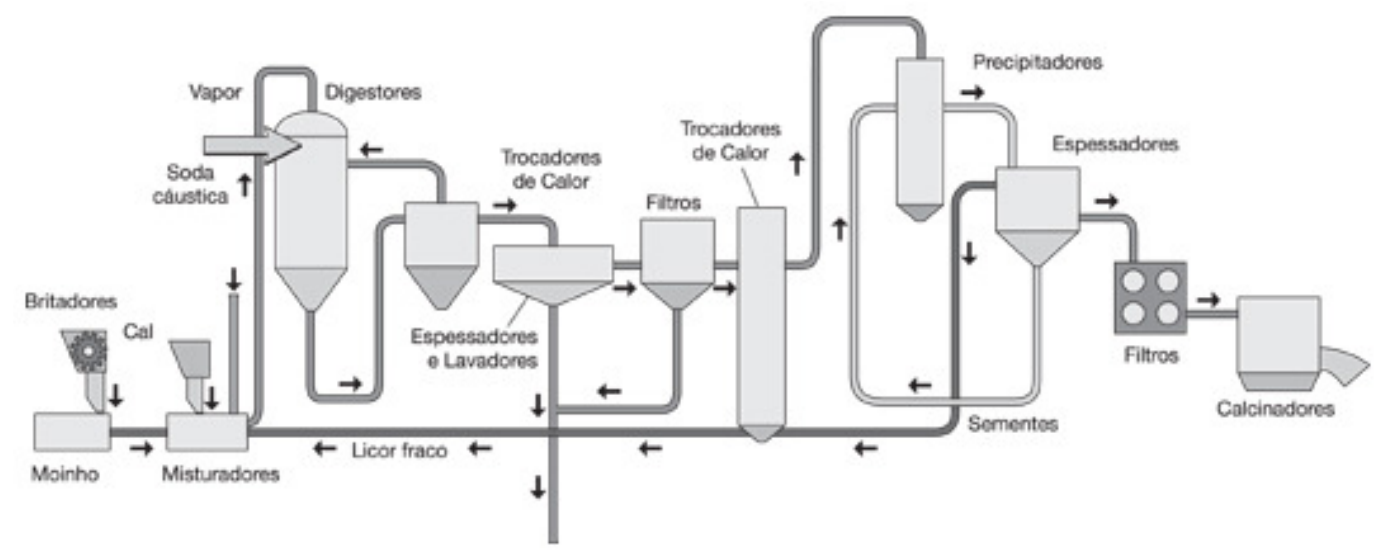

Figura 7 - Fluxograma básico de uma refinaria

\subsection{A OBTENÇÃO DO ALUMÍNIO}

O processo de obtenção do alumínio primário, após a obtenção da alumina é o conhecido Hall-Heroult.

A alumina é, então, levada às cubas eletrolíticas, onde se formam os sais de criolita e o fluoreto de alumínio; a passagem de corrente elétrica na cuba promove a redução da alumina, que consiste em extrair o metal de seu óxido. $A$ reação total decorrente da passagem da corrente elétrica, que ocorre no forno, consiste na redução da alumina, liberando o alumínio que é depositado no catodo, e na oxidação do carbono do anodo, devido ao oxigênio liberado no processo. 


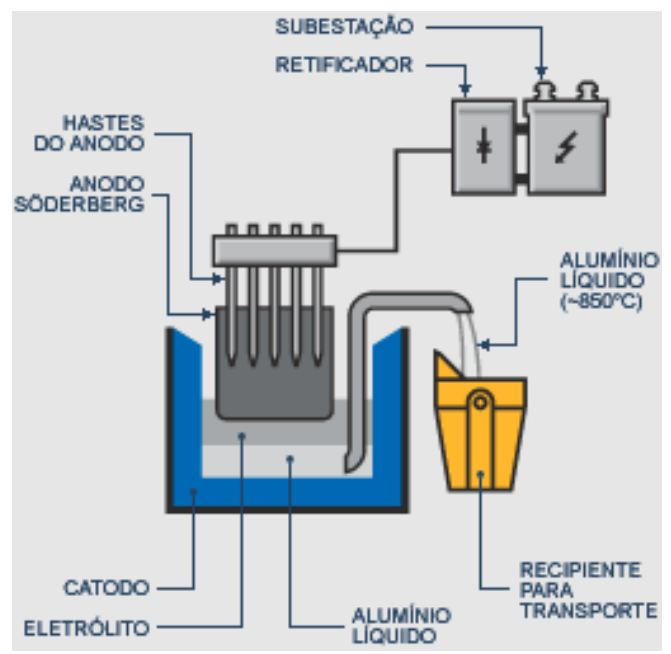

Figura 8 - Diagrama esquemático da obtenção do Alumínio

O alumínio sai das cubas no estado líquido, a aproximadamente $850^{\circ} \mathrm{C}$, e é então transportado para a fundição, onde são ajustadas a sua composição química e forma física.

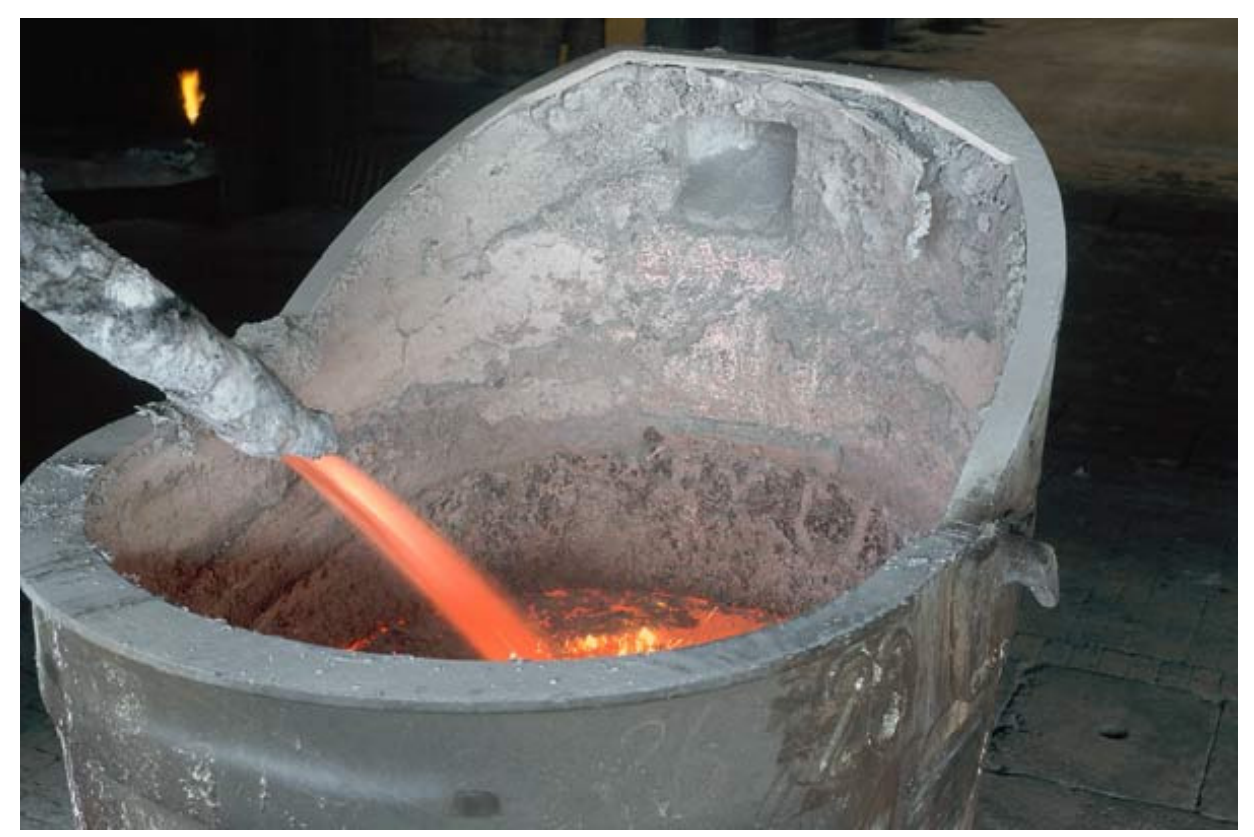

Figura 9 - Alumínio líquido retirado das cubas eletrolíticas 
Após a obtenção do alumínio líquido, esse é transportado para os fornos de fundição, onde podem ser transformados em lingotes, tarugos, placas, rolos caster e vergalhões, em diversas ligas, dependendo de seu tipo de aplicação.

\subsection{A INDÚSTRIA DO ALUMÍNIO}

\subsubsection{No Mundo}

A importância do alumínio hoje, no mundo, pode ser demonstrada através dos seguintes números de produção e consumo. De acordo com a The Aluminium Association, World Bureau os Metal Statistics e LME (London Metal Exchange), em 2006 o consumo de alumínio no mundo cresceu $7,3 \%$ acima do volume registrado em 2005 e a produção neste mesmo espaço de tempo cresceu apenas 3,4\%, mostrando que a indústria de alumínio no mundo tem evolução crescente, e seu consumo é superior à produção, como podemos observar na tabela 2 , separada por continente.

Unidade: 1.000 toneladas

\begin{tabular}{lrr}
\multicolumn{1}{c}{ Áreas } & \multicolumn{2}{c}{$\mathbf{2 0 0 6}$} \\
África & Produção & Consumo \\
América & $1.865,1$ & 482,0 \\
Ásia & $7.825,7$ & $8.393,2$ \\
Europa & $13.089,8$ & $15.995,5$ \\
Oceania & $8.901,8$ & $8.777,9$ \\
Total & $2.270,0$ & 374,3 \\
\hline & $\mathbf{3 3 . 9 5 2 , 4}$ & $\mathbf{3 4 . 0 2 2 , 9}$
\end{tabular}

Tabela 2 - Produção e Consumo Mundial de Alumínio (ABAL, Anuário Estatístico 2006)

O aumento de consumo deste metal não-ferroso está relacionado às suas propriedades físico-químicas. Se comparado com outros metais mais populares, podemos destacar seu baixo peso específico, bem como sua resistência à 
corrosão e alta condutibilidade elétrica e térmica, propriedades estas muito valiosas para setores como, por exemplo, o da construção civil e automotivo.

O setor que mais emprega o alumínio no mundo é o de transportes, em que podemos destacar o Japão, com 40,5\% destinados a este setor (ABAL, Anuário Estatístico 2006).

Um fato interessante está relacionado com a renda per capta, podemos evidenciar um elevado consumo de alumínio por habitante em países cujo poder aquisitivo é maior, o que significa que é possível afirmar que o consumo de alumínio é diretamente proporcional à renda anual por habitante.

\subsubsection{No Brasil}

O Brasil está dentre os maiores produtores de alumínio do mundo, conforme podemos destacar através da tabela 1, possui a terceira maior jazida de bauxita do planeta, tem a quinta maior produção de alumina do mundo e, além disso, é o sexto em alumínio primário.

Outro destaque importante do alumínio brasileiro é que sua participação no mercado global é bastante relevante, sendo o quinto maior exportador da matériaprima.

No mercado interno, a maior parte do alumínio e de seus produtos é aplicada nos mercados de embalagens e transportes. Em seguida, aparecem os setores de construção civil, eletricidade e bens de consumo. A produção de semimanufaturados de alumínio no Brasil está concentrada no sudeste do Brasil. Minas Gerais, São Paulo e Rio de Janeiro abrigam empresas produtoras de chapas, folhas, extrudados e cabos. O segmento também está presente nos estados do Pará, Ceará, Pernambuco, Bahia, Paraná e Rio Grande do Sul.

O ano de 2006, para o Brasil, foi marcado pela ascensão de alguns números importantes, o consumo de alumínio passou a 4,6 kg/hab/ano, ante os 
4,4 kg/hab/ano registrados em 2005, que apesar de estar bastante defasado em relação aos números de consumo por habitante registrado nos países de primeiro mundo, que é de $27 \mathrm{~kg} / \mathrm{hab} / \mathrm{ano}$, pode-se considerar como um número expressivo.

O aumento significativo no consumo pode ser percebido através dos números dos produtos transformados de alumínio, cujo crescimento foi de $4,4 \%$, conforme tabela 3 a seguir:

Unidade: 1.000 toneladas / ano

\begin{tabular}{lccc}
\multicolumn{1}{c}{ Produtos } & $\mathbf{2 0 0 5}$ & $\mathbf{2 0 0 6}$ & $\mathbf{2 0 0 6} / \mathbf{2 0 0 5}$ \\
\hline Chapas & 297,3 & 310,7 & $4,5 \%$ \\
Folhas & 70,7 & 72,3 & $2,3 \%$ \\
Extrudados & 128,4 & 136,8 & $6,5 \%$ \\
\hline Fios/Cabos & 85,1 & 86,8 & $2,0 \%$ \\
Fundidos & 149,3 & 157,6 & $5,6 \%$ \\
Pó & 23 & 24,4 & $6,1 \%$ \\
Destrutivos & 37,7 & 36,9 & $-2,1 \%$ \\
Outros & 10,8 & 12,1 & $12,0 \%$ \\
Total & $\mathbf{8 0 2 , 3}$ & $\mathbf{8 3 7 , 6}$ & $\mathbf{4 , 4 \%}$
\end{tabular}

Tabela 3 - Consumo Doméstico de Produtos de Transformados (ABAL, Anuário Estatístico 2006)

Através da tabela 4, é percebida a fase de consolidação do uso do alumínio no setor de transportes e construção civil, com o crescimento de $6,5 \%$ nos produtos extrudados, mostrando ser um segmento estratégico e com grande potencial de consumo. Também se pode destacar o contínuo crescimento no consagrado setor de embalagens, com 6,9\%. 
Unidade: 1.000 toneladas / ano

\begin{tabular}{lccc}
\multicolumn{1}{c}{ Setor } & $\mathbf{2 0 0 5}$ & $\mathbf{2 0 0 6}$ & $\mathbf{2 0 0 6} / \mathbf{2 0 0 5}$ \\
\hline Construção Civil & 89,8 & 95,2 & $6,0 \%$ \\
\hline Transportes & 202,5 & 213,1 & $5,2 \%$ \\
\hline Eletricidade & 100,6 & 102,9 & $2,3 \%$ \\
Bens de Consumo & 65,7 & 70,2 & $6,8 \%$ \\
Embalagens & 225,2 & 240,7 & $6,9 \%$ \\
Máquinas e Equipamentos & 34,1 & 33,9 & $-0,6 \%$ \\
Outros & 84,4 & 81,6 & $-3,3 \%$ \\
Total & $\mathbf{8 0 2 , 3}$ & $\mathbf{8 3 7 , 6}$ & $\mathbf{4 , 4} \%$
\end{tabular}

Tabela 4 - Consumo de Alumínio por Setor de Aplicação (ABAL, Anuário Estatístico 2006)

\subsubsection{As empresas do setor}

O suprimento do alumínio no Brasil, responsável pelos números apresentados, tem como principais indústrias de alumínio primário: Albras, Alcoa, Alumar, CBA, Novelis e Valesul.

A Alumínio Brasileiro S.A. (Albras) é uma empresa resultante de uma associação da Companhia Vale do Rio Doce (CVRD) e da Nippon Amazon Aluminium Co. Ltd. (NAAC), esta última, sendo um consórcio de 17 empresas japonesas. A empresa foi inaugurada em julho 1985, no município de Barbacena, estado do Pará.

A produção de alumínio primário da Albrás em 2006, de acordo com a ABAL, foi de 459,9 mil toneladas, superior em $2,3 \%$ em relação ao produzido em 2005.

A Alcoa Alumínio S.A. (Alcoa) é uma empresa de origem americana, subsidiária da Alcoa Inc., foi fundada no ano de 1886, e é uma das maiores produtoras mundial de alumínio. No Brasil, sua primeira fábrica foi inaugurada em 1965, localizada em Poços de Caldas, no estado de Minas Gerais. 
A produção de alumínio primário da Alcoa, em 2006, de acordo com a ABAL, foi de 356,6 mil toneladas, superior em $18,5 \%$ em relação ao produzido em 2005.

O Consórcio de Alumínio do Maranhão (Alumar) é formado pelas empresas Alcoa, BHP Billiton e Alcan. Foi fundado em 1980 no estado do Maranhão, e é um dos maiores complexos de alumina e alumínio do mundo.

A produção de alumínio primário da Alumar em 2006, de acordo com a ABAL, foi de 437,9 mil toneladas, superior em $15 \%$ em relação ao produzido em 2005.

A Companhia Brasileira de Alumínio (CBA) é uma empresa do Grupo Votorantim, sua fábrica foi fundada em 1955 na cidade de Alumínio, em São Paulo, e é a maior planta do mundo a operar de forma totalmente verticalizada, realizando, num mesmo local, desde o processamento da bauxita até a fabricação de produtos.

A produção de alumínio primário da CBA em 2006, de acordo com a ABAL, foi de 404,9 mil toneladas, superior em 9,3 \% em relação ao produzido em 2005.

A Novelis Brasil Ltda (Novelis) é uma empresa de origem americana, subsidiária da Novelis Inc., foi fundada no Brasil no ano de 1940, porém, somente começou sua fabricação em 1948 , devido à $2^{\text {a }}$ Guerra Mundial. As fábricas de alumínio primário estão localizadas em Aratu, na Bahia, e em Ouro Preto, em Minas Gerais, e ainda possui duas fábricas de transformados, ambas no estado de São Paulo, sendo uma em Pindamonhangaba e outra em Santo André.

A produção de alumínio primário da Novelis, em 2006, de acordo com a ABAL, foi de 109,9 mil toneladas, superior em 2,1\% em relação ao produzido em 2005.

A Vale do Rio Doce Alumínio S.A. (Aluvale) é uma "holding" da área de alumínio do sistema CVRD desde 31/12/2003, composta pela Mineração Rio do Norte S.A. (MRN), na área de produção de bauxita, pela Alumina do Norte do 
Brasil S.A. (Alunorte), produtora de alumina, e pelas Albras e Valesul Alumínio S.A. (VALESUL), produtoras de alumínio primário.

\begin{tabular}{llcccccc}
\multicolumn{1}{c}{ Produtores } & \multicolumn{1}{c}{ Localização } & $\mathbf{2 0 0 1}$ & $\mathbf{2 0 0 2}$ & $\mathbf{2 0 0 3}$ & $\mathbf{2 0 0 4}$ & $\mathbf{2 0 0 5}$ & $\mathbf{2 0 0 6}$ \\
\cline { 2 - 8 } Albras & Barbacena (PA) & 334,8 & 416,1 & 435,9 & 440,5 & 449,5 & 459,9 \\
Alcoa & Poços de Caldas (MG) & 69,7 & 88,1 & 94,9 & 90,3 & 95,3 & 96,1 \\
Alumar & São Luís (MA) & 325,1 & 370,5 & 334,9 & 377,2 & 380,8 & 437,9 \\
CBA & Alumínio (SP) & 230,4 & 248,8 & 313,8 & 345,3 & 370,4 & 404,9 \\
Novelis & Ouro Preto (MG) & 44,5 & 49,5 & 50,2 & 51,0 & 50,6 & 51,4 \\
Novelis & Aratu (BA) & 47,6 & 52,5 & 56,3 & 57,8 & 57 & 58,5 \\
Valesul & Santa Cruz (RJ) & 79,9 & 92,9 & 94,6 & 95,3 & 94 & 95,8 \\
Total & & $\mathbf{1 1 3 2}$ & $\mathbf{1 . 3 1 8 , 4}$ & $\mathbf{1 3 8 0 , 6}$ & $\mathbf{1 . 4 5 7 , 4}$ & $\mathbf{1 4 9 7 , 6}$ & $\mathbf{1 . 6 0 4 , 5}$
\end{tabular}

Tabela 5 - Produção de Alumínio Primário por Usina (ABAL, Anuário Estatístico 2006)

Há de se destacar outros importantes números sócio-econômicos da indústria brasileira de alumínio. Os empregos diretos aumentaram quase 6\%, fechando o ano de 2006 com 58.202 de vagas ocupadas, frente aos 55.068 registrados em 2005 .

O segmento representa 1,1\% do Produto Interno Bruto (PIB) brasileiro, com faturamento de US\$12,1 bilhões.

Através da tabela 5 , pode-se destacar que o crescimento da indústria de alumínio do período de 2001 a 2006 foi de quase 42\%, muito superior ao crescimento brasileiro.

\subsubsection{As Projeções de Produção}

\subsection{Alumínio Primário}

No ano de 2006, segundo o balanço de produção de alumínio primário elaborado pela ABAL e publicado no Anuário Estatístico 2006, ocorreu um incremento na produção de alumínio de 102 mil toneladas, se comparado ao 
resultado obtido em 2005. Resultados estes influenciados pelo acréscimo de produção da CBA e da Alcoa, na unidade fabril da Alumar.

Para o ano de 2007, o principal investimento no acréscimo da capacidade de produção fica para a CBA, passando das atuais 405 mil toneladas/ano para 475 mil toneladas/ano, e com previsão de acréscimo para 615 mil toneladas/ano até $\mathrm{o}$ ano de 2010.

Segundo estudos e dados divulgados pela Empresa de Pesquisa Energética (EPE), a indústria de alumínio primário tem projeções de crescimento médio de 3,5\% ao ano, conforme podemos visualizar nas tabelas 6 e 7 . Esse crescimento está pouco abaixo da média de crescimento de outros setores industriais, talvez justificado pela possibilidade de restrições de consumo de energia futuras, por se tratar de um dos principais insumos para fabricação.

\begin{tabular}{|c|c|c|c|c|c|c|}
\hline \multirow{2}{*}{ Setores } & \multirow{2}{*}{2006} & \multirow{2}{*}{2011} & \multirow{2}{*}{2016} & \multicolumn{3}{|c|}{ Variação (\% ao ano) } \\
\hline & & & & 2006/11 & $2011 / 16$ & $2006 / 16$ \\
\hline Alumínio & 1.605 & 1.865 & 2.460 & $2,8 \%$ & $4,8 \%$ & $3,5 \%$ \\
\hline Siderurgia & 33.409 & 44.475 & 62.875 & $5,0 \%$ & $5,9 \%$ & $4,7 \%$ \\
\hline Celulose & 10.278 & 12.613 & 15.908 & $3,7 \%$ & $4,1 \%$ & $3,5 \%$ \\
\hline PAR & 450 & 878 & 1.068 & $9,7 \%$ & $3,6 \%$ & $5,8 \%$ \\
\hline Papel & 9.114 & 11.976 & 16.305 & $4,8 \%$ & $5,3 \%$ & $4,4 \%$ \\
\hline Ferroligas & 1.239 & 1.564 & 2.028 & $4,2 \%$ & $4,6 \%$ & $3,9 \%$ \\
\hline Petroquímica & 2.948 & 4.305 & 6.526 & $6,3 \%$ & $6,8 \%$ & $5,5 \%$ \\
\hline Soda-Cloro & 1.389 & 1.784 & 2.352 & $4,4 \%$ & $4,8 \%$ & $4,1 \%$ \\
\hline Cimento & 38.722 & 50.694 & 68.283 & $4,7 \%$ & $5,2 \%$ & $4,3 \%$ \\
\hline Pelotização & 46.460 & 65.320 & 71.760 & $5,8 \%$ & $1,8 \%$ & $3,5 \%$ \\
\hline Cobre & 388 & 2.179 & 2.515 & $16,4 \%$ & $2,7 \%$ & $8,5 \%$ \\
\hline
\end{tabular}

Tabela 6 - Projeções de Produção de Alumínio e Outros (ABAL, Anuário Estatístico 2006)

Outro número que pode ser destacado através da tabela 7 , divulgada no Anuário Estatístico da ABAL de 2006, é que se excetuando a Alumínio BM, que projeta construir uma nova planta de 230 mil toneladas/ano em 2015 e dobrar sua produção em 2016, as empresas Albrás e CBA, e em menor escala a Alcoa, preconizam em realizar suas expansões em suas próprias plantas, podendo ser 
motivada pela maior facilidade de acesso às redes de transmissão de energia, acarretando, assim, em menores custos de ampliação.

\begin{tabular}{lccccccccccc}
\multicolumn{1}{c}{ Unidade } & UF & $\mathbf{2 0 0 7}$ & $\mathbf{2 0 0 8}$ & $\mathbf{2 0 0 9}$ & $\mathbf{2 0 1 0}$ & $\mathbf{2 0 1 1}$ & $\mathbf{2 0 1 2}$ & $\mathbf{2 0 1 3}$ & $\mathbf{2 0 1 4}$ & $\mathbf{2 0 1 5}$ & $\mathbf{2 0 1 6}$ \\
\hline Albrás & PA & 450 & 450 & 450 & 480 & 480 & 480 & 585 & 585 & 585 & 585 \\
Alumar & MA & 470 & 470 & 470 & 470 & 470 & 470 & 470 & 470 & 470 & 470 \\
Alumínio BM & PA/MA & 0 & 0 & 0 & 0 & 0 & 0 & 0 & 0 & 230 & 460 \\
CBA & SP & 475 & 475 & 475 & 475 & 615 & 615 & 615 & 615 & 615 & 615 \\
Alcoa PC & MG & 110 & 112 & 123 & 123 & 123 & 123 & 123 & 123 & 123 & 123 \\
Valesul & RJ & 98 & 98 & 98 & 98 & 98 & 98 & 98 & 98 & 98 & 98 \\
Novelis - Ouro Preto & MG & 51 & 51 & 51 & 51 & 51 & 51 & 51 & 51 & 51 & 51 \\
Novelis - Aratu & BA & 58 & 58 & 58 & 58 & 58 & 58 & 58 & 58 & 58 & 58 \\
Total & & $\mathbf{1 . 7 1 2}$ & $\mathbf{1 . 7 1 4}$ & $\mathbf{1 . 7 2 5}$ & $\mathbf{1 . 7 5 5}$ & $\mathbf{1 . 8 9 5}$ & $\mathbf{1 . 8 9 5}$ & $\mathbf{2 . 0 0 0}$ & $\mathbf{2 . 0 0 0}$ & $\mathbf{2 . 2 3 0}$ & $\mathbf{2 . 4 6 0}$
\end{tabular}

Tabela 7 - Produção de Alumínio Primário (ABAL, Anuário Estatístico 2006)

Das projeções atuais de produção de alumínio primário para 2007, de 1.712 mil toneladas/ano até os $2.460 \mathrm{mil}$ toneladas/ano projetados para 2016, demonstrando um crescimento médio de 3,5\%, o que é diferente dos crescimentos projetados para a fabricação da alumina, conforme podemos visualizar através da tabela 9. 


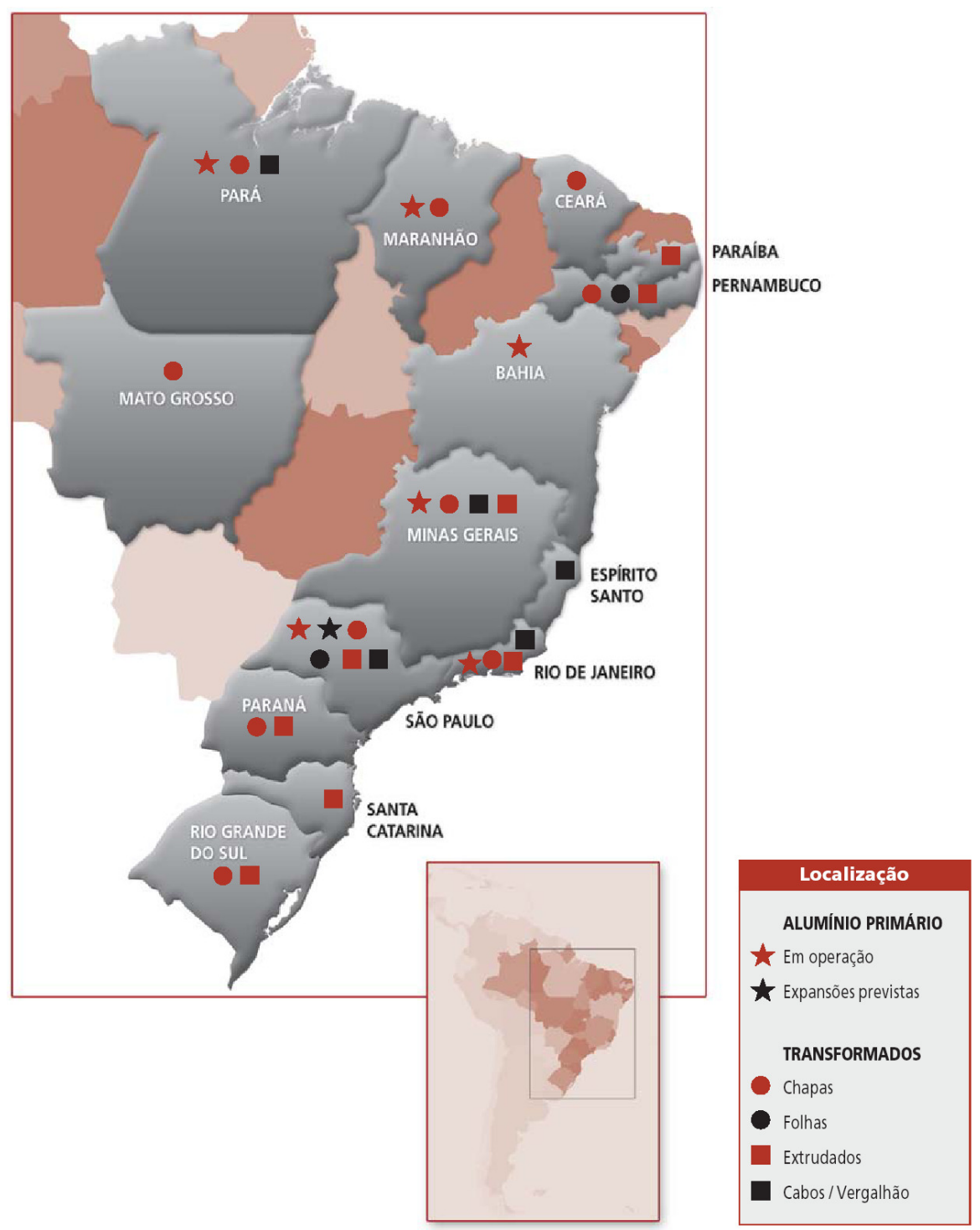

Figura 10 - Mapa de localização das plantas de Alumínio Primário (ABAL, Anuário Estatístico 2006)

\subsection{Alumina}

No ano de 2006, segundo o balanço de produção de alumina elaborado pela ABAL e publicado no Anuário Estatístico 2006, ocorreu um incremento na produção de alumina de 1.519,1 toneladas, se comparado ao resultado obtido em 2005, um aumento de $29,2 \%$ totalizando uma produção total de $6.720,2$ toneladas no ano. Resultados estes influenciados diretamente pelo acréscimo de produção 
da Alunorte Alumina do Brasil S.A, sendo esta a principal produtora de alumina no Brasil, com 3.939 mil toneladas no ano, conforme podemos identificar através da tabela 8.

\begin{tabular}{|c|c|c|c|}
\hline \multirow{2}{*}{ Descrição } & \multicolumn{3}{|c|}{ Alumina } \\
\hline & 2004 & 2005 & 2006 \\
\hline Suprimento & $5.134,5$ & $5.226,6$ & $6.793,0$ \\
\hline Produção & $5.126,5$ & $5.201,1$ & $6.720,2$ \\
\hline Alcan & 139,5 & 137,3 & 144,0 \\
\hline Alcoa & $1.074,3$ & $1.105,1$ & $1.163,3$ \\
\hline Poços de Caldas - MG & 321,2 & 363,8 & 369,4 \\
\hline São Luís - MA & 753,1 & 741,3 & 793,9 \\
\hline Alunorte & $2.548,3$ & $2.570,2$ & $3.939,0$ \\
\hline BHP Billiton & 502,3 & 494,2 & 503,5 \\
\hline CBA & 729,9 & 771,0 & 840,6 \\
\hline Novelis & 132,2 & 123,3 & 129,8 \\
\hline MRN & - & - & - \\
\hline Outros & - & - & - \\
\hline Importações & 8,0 & 35,5 & 72,8 \\
\hline Consumo Doméstico & $3.003,6$ & $3.019,5$ & $3.240,6$ \\
\hline Usos Metálicos & $2.820,4$ & $2.886,1$ & $3.097,5$ \\
\hline Outros usos & 183,2 & 133,4 & 143,1 \\
\hline Exportações & $1.921,4$ & $2.327,1$ & $3.380,6$ \\
\hline
\end{tabular}

Tabela 8 - Suprimentos e Consumo de Alumina (ABAL, Anuário Estatístico 2006)

Com um crescimento da produção de alumina total projetado de $102 \%$, se comparados à produção programada para 2007 com a projetada para 2016, podese identificar uma maior independência das questões de crescimento energético, já que para sua produção não são de grande relevância.

Neste segmento, a Alunorte destaca-se pelos investimentos na ampliação de sua produção, prevendo em 2007 passar a 4,4 milhões de toneladas de 
alumina, o que a torna a maior planta do mundo de refino, prevendo ainda novos investimentos para atingir em 2008 a produção de 6,3 milhões de toneladas.

\begin{tabular}{lcccccccccccc}
\multicolumn{1}{c}{ Unidade } & UF & $\mathbf{2 0 0 7}$ & $\mathbf{2 0 0 8}$ & $\mathbf{2 0 0 9}$ & $\mathbf{2 0 1 0}$ & $\mathbf{2 0 1 1}$ & $\mathbf{2 0 1 2}$ & $\mathbf{2 0 1 3}$ & $\mathbf{2 0 1 4}$ & $\mathbf{2 0 1 5}$ & $\mathbf{2 0 1 6}$ \\
\hline Alunorte & PA & 4.400 & 6.300 & 6.300 & 6.300 & 6.300 & 6.300 & 6.300 & 6.300 & 6.300 & 6.300 \\
CVRD - Paragominas & PA & 1.410 & 2.820 & 2.820 & 2.820 & 2.820 & 2.820 & 2.820 & 2.820 & 2.820 & 2.820 \\
Alcoa - Juruti & PA & 0 & 1.680 & 1.680 & 1.680 & 1.680 & 1.680 & 1.680 & 1.680 & 1.680 & 1.680 \\
Alumina ABC & PA & 0 & 0 & 1.000 & 1.000 & 1.000 & 1.000 & 1.000 & 1.000 & 1.000 & 1.000 \\
Alumar Refinaria & MA & 1.400 & 1.400 & 3.500 & 3.500 & 3.500 & 3.500 & 3.500 & 3.500 & 3.500 & 3.500 \\
CBA & SP & 1.512 & 1.932 & 2.352 & 2.352 & 2.352 & 2.352 & 2.352 & 2.352 & 2.352 & 2.352 \\
Total & & $\mathbf{8 . 7 2 2}$ & $\mathbf{1 4 . 1 3 2}$ & $\mathbf{1 7 . 6 5 2}$ & $\mathbf{1 7 . 6 5 2}$ & $\mathbf{1 7 . 6 5 2}$ & $\mathbf{1 7 . 6 5 2}$ & $\mathbf{1 7 . 6 5 2}$ & $\mathbf{1 7 . 6 5 2}$ & $\mathbf{1 7 . 6 5 2}$ & $\mathbf{1 7 . 6 5 2}$
\end{tabular}

Tabela 9 - Produção de Alumina (ABAL, Anuário Estatístico 2006)

\subsection{Bauxita}

No ano de 2006, segundo o balanço de produção de bauxita elaborado pela ABAL e publicado no Anuário Estatístico 2006, ocorreu um incremento na produção de bauxita de 832,7 toneladas, se comparado ao resultado obtido em 2005, um aumento de 3,6\% totalizando uma produção de $22.913,9$ toneladas no ano. Resultados estes influenciados diretamente pelo acréscimo de produção da Mineração Rio do Norte S.A (MRN), no Pará, e pela CBA, em São Paulo, sendo a MRN a principal produtora de bauxita no Brasil com 17.750,3 mil toneladas no ano. 
Unidade: 1.000 toneladas

\begin{tabular}{|c|c|c|c|}
\hline \multirow{2}{*}{ Descrição } & \multicolumn{3}{|c|}{ Bauxita } \\
\hline & 2004 & 2005 & 2006 \\
\hline Suprimento & $20.548,3$ & $22.081,2$ & $22.913,9$ \\
\hline Produção & $20.511,8$ & $22.034,6$ & $22.836,3$ \\
\hline Alcan & - & - & - \\
\hline \multicolumn{4}{|l|}{ Alcoa } \\
\hline Poços de Caldas - MG & 788,5 & $1.068,2$ & $1.180,6$ \\
\hline São Luís - MA & - & - & - \\
\hline Alunorte & - & - & - \\
\hline BHP Billiton & - & - & - \\
\hline CBA & $2.232,7$ & $2.461,2$ & $2.785,0$ \\
\hline Novelis & - & 451,7 & 461,2 \\
\hline MRN & $16.749,1$ & $17.211,4$ & $17.750,3$ \\
\hline Outros & 741,5 & 842,1 & 659,2 \\
\hline Importações & 36,5 & 46,6 & 77,6 \\
\hline Consumo Doméstico & $12.564,1$ & $13.043,2$ & $16.680,8$ \\
\hline Usos Metálicos & $11.861,1$ & $12.200,2$ & $15.847,5$ \\
\hline Outros usos & 703,0 & 843,0 & 833,3 \\
\hline Exportações & $7.290,5$ & $7.508,7$ & $5.309,5$ \\
\hline
\end{tabular}

Tabela 10 - Suprimento e Consumo de Bauxita (ABAL, Anuário Estatístico 2006)

Talvez pelo mesmo motivo da produção de alumina, sua independência energética, e mais que isso, a riqueza deste mineral no Brasil, a produção de bauxita projeta crescer $80 \%$ até 2016 , se comparadas às programações de produção para 2007, conforme se pode constatar nas tabelas 8 e 9.

A CBA pretende iniciar no ano de 2007 as atividades para a extração da bauxita em Miraí (MG), com previsão inicial de extrair 3 milhões de toneladas por ano.

A CVRD pretende investir na extração da bauxita em Paragominas (PA), passando a extrair 9,9 milhões de toneladas/ano, com início previsto para 2008, um acréscimo de 83,3\% na produção atual de 5,4 milhões de toneladas/ano. 
A Alcoa, a partir de 2008, em sua mina de Juruti (PA), pretende dar início à extração de 2,6 milhões de toneladas/ano de bauxita.

Um fato de destaque no Brasil, é que a maior parte da mineração de bauxita está no estado do Pará, o que podemos visualizar através da tabela 11, identificando um fator de economia na logística de transporte.

\begin{tabular}{lccccccccccc}
\multicolumn{1}{c}{ Unidade } & UF & $\mathbf{2 0 0 7}$ & $\mathbf{2 0 0 8}$ & $\mathbf{2 0 0 9}$ & $\mathbf{2 0 1 0}$ & $\mathbf{2 0 1 1}$ & $\mathbf{2 0 1 2}$ & $\mathbf{2 0 1 3}$ & $\mathbf{2 0 1 4}$ & $\mathbf{2 0 1 5}$ & $\mathbf{2 0 1 6}$ \\
\hline MRN & PA & 17.600 & 17.600 & 17.600 & 17.600 & 17.600 & 17.600 & 17.600 & 17.600 & 17.600 & 17.600 \\
Alcoa - Juruti & PA & 0 & 2.600 & 2.600 & 6.300 & 6.300 & 10.000 & 10.000 & 10.000 & 10.000 & 10.000 \\
CVRD - Paragominas & PA & 2.700 & 5.400 & 9.900 & 9.900 & 9.900 & 9.900 & 9.900 & 9.900 & 9.900 & 9.900 \\
CBA & MG & 3.600 & 4.600 & 5.600 & 5.600 & 5.600 & 5.600 & 5.600 & 5.600 & 5.600 & 5.600 \\
Total & & $\mathbf{2 3 . 9 0 0}$ & $\mathbf{3 0 . 2 0 0}$ & $\mathbf{3 5 . 7 0 0}$ & $\mathbf{3 9 . 4 0 0}$ & $\mathbf{3 9 . 4 0 0}$ & $\mathbf{4 3 . 1 0 0}$ & $\mathbf{4 3 . 1 0 0}$ & $\mathbf{4 3 . 1 0 0}$ & $\mathbf{4 3 . 1 0 0}$ & $\mathbf{4 3 . 1 0 0}$
\end{tabular}

Tabela 11 - Produção de Bauxita (ABAL, Anuário Estatístico 2006)

\subsubsection{A Representatividade na Economia Brasileira}

A representatividade da indústria de alumínio na economia brasileira não pode ser expressa somente com os números expressivos de aumento de produção de bauxita, alumina e alumínio primário, outros fatores importantes devem ser notados.

Resumidamente, em 2006, refletindo os desempenhos internos e externos, a indústria de alumínio brasileira faturou US\$ 12 bilhões, com participação de 4,3\% do total do Produto Interno Bruto, PIB, do Brasil.

No aspecto social, podemos destacar que em 2006 foram criados cerca de 3.100 empregos diretos, quase que $6 \%$ a mais que em 2005, totalizando 58.202 vagas ocupadas, como podemos ver na tabela 12. 


\begin{tabular}{|l|ccc|cccc|}
\hline \multicolumn{1}{c|}{ Setor } & \multicolumn{3}{c}{$\mathbf{2 0 0 5}$} & \multicolumn{3}{c|}{$\mathbf{2 0 0 6}$} \\
Primário/Integrado & Administrativo & Técnico & Total & Administrativo & Técnico & Total \\
\hline Secundário & 3.280 & 14.966 & $\mathbf{1 8 . 2 4 6}$ & 3.614 & 16.105 & $\mathbf{1 9 . 7 1 9}$ \\
Transformadores & 340 & 1.081 & $\mathbf{1 . 4 2 1}$ & 349 & 1.106 & $\mathbf{1 . 4 5 5}$ \\
\hline Total & 5.215 & 30.186 & $\mathbf{3 5 . 4 0 1}$ & 5.488 & 31.540 & $\mathbf{3 7 . 0 2 8}$ \\
& $\mathbf{8 . 8 3 5}$ & $\mathbf{4 6 . 2 3 3}$ & $\mathbf{5 5 . 0 6 8}$ & $\mathbf{9 . 4 5 1}$ & $\mathbf{4 8 . 7 5 1}$ & $\mathbf{5 8 . 2 0 2}$ \\
\hline
\end{tabular}

Tabela 12 - Empregos Diretos (ABAL, Anuário Estatístico 2006)

$\mathrm{Na}$ balança comercial, os resultados apresentados no ano de 2006 comprovam a significativa melhora em seu desempenho, o saldo comercial foi de US\$ 3,6 bilhões FOB, com substancial participação de 7,9\% da balança comercial brasileira, sendo US\$ 4,3 bilhões FOB nas exportações, correspondendo a 3,1\% do total das exportações brasileiras, e US\$ 0,6 bilhões FOB nas importações, como podemos identificar na tabela 13.

\begin{tabular}{|c|c|c|c|c|c|c|c|c|c|}
\hline \multirow[b]{2}{*}{ Período } & \multicolumn{3}{|c|}{ Exportação } & \multicolumn{3}{|c|}{ Importação } & \multicolumn{3}{|c|}{ Saldo } \\
\hline & Brasil & $\begin{array}{l}\text { Ind. do } \\
\text { Alumínio }\end{array}$ & $\%$ & Brasil & $\begin{array}{l}\text { Ind. do } \\
\text { Alumínio }\end{array}$ & $\%$ & Brasil & $\begin{array}{l}\text { Ind. do } \\
\text { Alumínio }\end{array}$ & $\%$ \\
\hline 1996 & 47.747 & 1.664 & $3,5 \%$ & 53.346 & 371 & $0,7 \%$ & (5.599) & 1.293 & - \\
\hline 1997 & 52.994 & 1.749 & $3,3 \%$ & 59.747 & 480 & $0,8 \%$ & $(6.753)$ & 1.269 & - \\
\hline 1998 & 51.140 & 1.563 & $3,1 \%$ & 57.764 & 548 & $0,9 \%$ & (6.624) & 1.015 & - \\
\hline 1999 & 48.011 & 1.702 & $3,5 \%$ & 49.295 & 467 & $0,9 \%$ & $(1.284)$ & 1.235 & - \\
\hline 2000 & 55.086 & 1.985 & $3,6 \%$ & 55.839 & 389 & $0,7 \%$ & (753) & 1.596 & - \\
\hline 2001 & 58.223 & 1.621 & $2,8 \%$ & 55.572 & 461 & $0,8 \%$ & 2.651 & 1.160 & $43,8 \%$ \\
\hline 2002 & 60.362 & 1.687 & $2,8 \%$ & 47.237 & 374 & $0,8 \%$ & 13.125 & 1.313 & $10,0 \%$ \\
\hline 2003 & 73.084 & 2.124 & $2,9 \%$ & 48.305 & 356 & $0,7 \%$ & 24.779 & 1.768 & $7,1 \%$ \\
\hline 2004 & 96.475 & 2.688 & $2,8 \%$ & 62.813 & 422 & $0,7 \%$ & 33.662 & 2.266 & $6,7 \%$ \\
\hline 2005 & 118.308 & 2.928 & $2,5 \%$ & 73.606 & 500 & $0,7 \%$ & 44.702 & 2.428 & $5,4 \%$ \\
\hline 2006 & 137.470 & 4.305 & $3,1 \%$ & 91.379 & 644 & $0,7 \%$ & 46.091 & 3.661 & $7,9 \%$ \\
\hline
\end{tabular}

No tocante às exportações, além dos números apresentados, é de se destacar que os volumes embarcados cresceram $11,6 \%$ se comparados aos de 2005, com um total de 1.070,1 mil toneladas, sendo que os principais volumes foram o alumínio primário e ligas, demonstrado na tabela 14. Esses volumes 
tiveram como principais destinos o Japão, a Suíça e os Estados Unidos, conforme figura 11.

\begin{tabular}{lcc}
\multicolumn{1}{c}{ Produto } & $\begin{array}{c}\text { Valor FOB } \\
(\mathbf{1 . 0 0 0} \text { US\$) }\end{array}$ & Participação \\
\hline Lingote & 1.494 .895 & $49,5 \%$ \\
Ligas & 586.721 & $19,4 \%$ \\
Sucata & 1.762 & $0,1 \%$ \\
Chapas & 289.778 & $9,6 \%$ \\
Folhas & 108.146 & $3,6 \%$ \\
Extrudados & 60.822 & $2,0 \%$ \\
Cabos & 140.716 & $4,7 \%$ \\
Pó & 7.903 & $0,3 \%$ \\
Utensílios Domésticos & 32.793 & $1,1 \%$ \\
Outros & 63.074 & $2,1 \%$ \\
Peças Fundidas & 235.853 & $7,8 \%$ \\
Total & $\mathbf{3 . 0 2 2 . 4 6 3}$ & $\mathbf{1 0 0 , 0 \%}$
\end{tabular}

Tabela 14 - Produtos Exportados em 2006 (ABAL, Anuário Estatístico 2006)

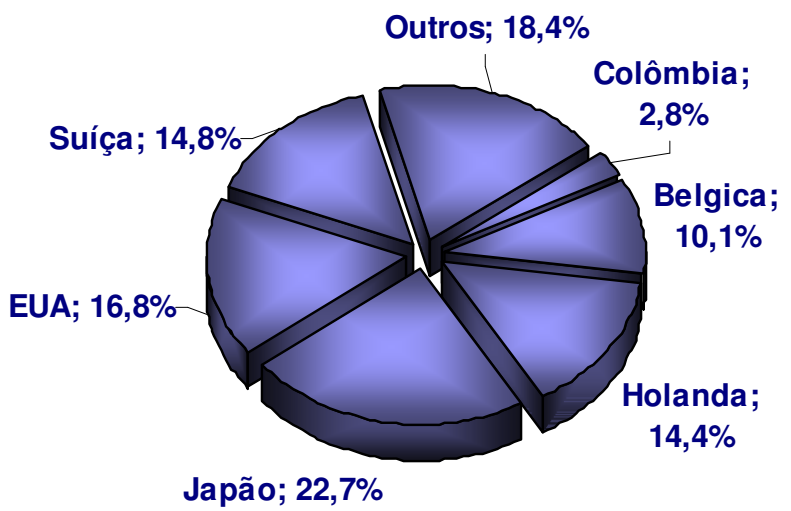

Figura 11 - Principais destinos das Exportações em 2006 (ABAL, Anuário Estatístico 2006)

No tocante às importações do ano de 2006, é possível identificar um crescimento de $7,5 \%$ com um volume de 139,9 mil toneladas provenientes, 
principalmente, da Alemanha, Argentina e Colômbia, conforme figura 12, com destaque para as chapas de alumínio que totalizaram 30,9 mil toneladas.

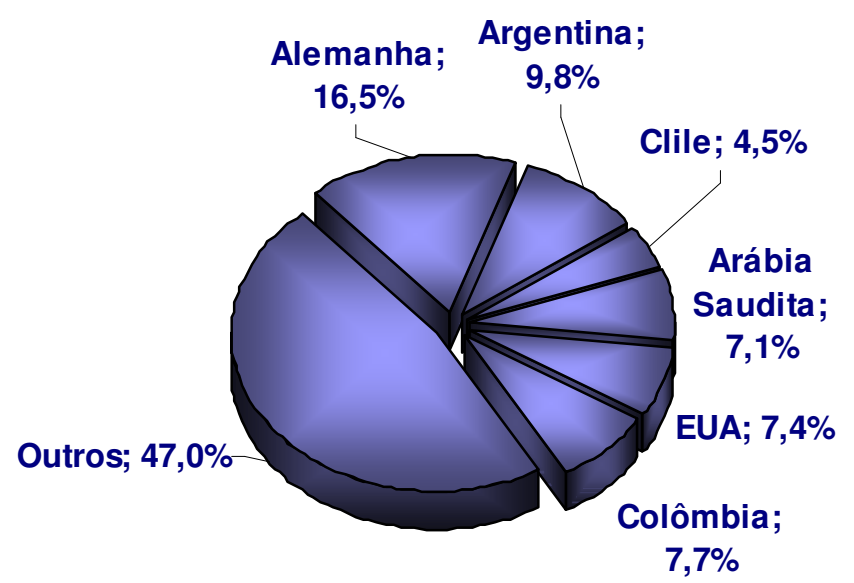

Gráfico 12 - Principais origens das Importações em 2006 (ABAL, Anuário Estatístico 2006)

Outro produto de destaque nas importações é a sucata, representando uma maior demanda de compra de $26,7 \%$ em relação a 2005 . O Brasil importa, em sua maioria, sucata visando à reciclagem.

\subsection{4. $\underline{\text { Reciclagem de Alumínio }}$}

O Brasil, feliz ou infelizmente, dependendo do ponto de vista, é um dos principais países em eficiência na reciclagem de alumínio, sendo a proporção entre consumo e reciclagem superior à média mundial, sendo que a média mundial está em 29,3\% e que o Brasil registrou em 2005 mais de 36\%.

O destaque do setor de reciclagem foi o de latas de alumínio, já que em 2005 foram mais de 294 mil toneladas, com um percentual de reciclagem de 
$96,2 \%$ do total produzido, o que pode mostrar uma preocupação com o meio ambiente, com a inclusão de coletas seletiva de lixo, como um problema social, em que pessoas, vulgo "catadores", coletam esse tipo de material em lixões, praças, lixeiras e praias, vendendo por preços ínfimos para gerar receita para sua própria subsistência.

O Brasil lidera o ranking de reciclagem de latas de alumínio desde 2001, e com isso chega a economizar $95 \%$ de energia na transformação da sucata em relação à transformação da bauxita até o alumínio primário.

\subsubsection{Energia Elétrica e Alumínio}

A produção de alumínio primário é caracterizada pelo consumo intensivo de energia elétrica, chamada de eletrointensivo. $O$ binômio energia e alumínio é facilmente encontrado em vários artigos e publicações.

Para se ter uma idéia de grandeza do consumo da indústria de alumínio no Brasil, a produção consumiu cerca de $6 \%$ do total de consumo de energia elétrica disponibilizada, ou $25.983 \mathrm{GWh}$, no ano 2006, sendo destes $23.973 \mathrm{GWh}$ para a produção de 1.604 mil toneladas de alumínio primário e $2.010 \mathrm{GWh}$ para a produção 6.720 mil toneladas de alumina, segundo a ABAL.

O custo da energia elétrica na fabricação do alumínio primário chega a alcançar de $35 \%$ a $40 \%$ que, juntamente com a alumina, compõem grande parte do custo de produção.

Para a produção de alumina, não somente energia elétrica se faz necessária, outros insumos podem ser destacados na cadeia de produção. $\mathrm{Na}$ tabela 15, a seguir, é possível verificar o consumo dos principais insumos registrados no ano de 2006. 


\begin{tabular}{lccc}
\multicolumn{1}{c}{ Insumos } & $\mathbf{2 0 0 5}$ & $\mathbf{2 0 0 6}$ & $\begin{array}{c}\text { Variação } \\
\text { \% }\end{array}$ \\
\hline Bauxita (1.000 toneladas) & 12200,2 & 15.848 & 29,90 \\
Óleo Combustível (1.000 toneladas) & 656,7 & 738 & 12,38 \\
Soda Cáustica (1.000 toneladas) & 491,5 & 641 & 30,32 \\
Energia Elétrica (GWh) & 1643,2 & 2.010 & 22,32 \\
Cal (1.000 toneladas) & 94,3 & 154 & 63,52
\end{tabular}

Tabela 15 - Insumos para a produção de Alumina em 2006 (ABAL, Anuário Estatístico 2006)

Além da bauxita e de combustíveis energéticos, a produção de uma tonelada de alumina requer outros elementos, cujo consumo depende da qualidade do minério, na tabela 16 é possível verificar esta variação.

$\begin{array}{lc}\text { Bauxita (t/t) } & 1,85 \text { a } 3,4 \\ \text { Cal }(\mathrm{kg} / \mathrm{t}) & 10 \text { a } 50 \\ \text { Soda cáustica }(\mathrm{kg} / \mathrm{t}) & 40 \text { a } 140 \\ \text { Vapor }(\mathrm{t} / \mathrm{t}) & 1,5 \text { a } 4,0 \\ \text { Óleo combustível - calcinação }(\mathrm{kg} / \mathrm{t}) & 80 \text { a } 130 \\ \text { Floculante sintético }(\mathrm{g} / \mathrm{t}) & 100 \text { a } 1000 \\ \text { Energia elétrica }(\mathrm{kwh} / \mathrm{t}) & 150 \text { a } 400 \\ \text { Produtividade }(\mathrm{Hh} / \mathrm{t}) & 0,5 \text { a } 3,0 \\ \text { Água } \mathrm{m}^{3 / \mathrm{t}} & 0,5 \text { a } 2,0\end{array}$

Tabela 16 - Elementos para a produção de Alumina (ABAL, Anuário Estatístico 2006)

Apesar do grande consumo de energia para a produção da alumina, a transformação da alumina em alumínio primário é o que requer a maior quantidade, além de outros elementos.

No ano de 2006, o total de insumos para a fabricação de alumínio primário são apresentados na tabela 17. 


\begin{tabular}{lccc}
\multicolumn{1}{c}{ Insumos } & $\mathbf{2 0 0 5}$ & $\mathbf{2 0 0 6}$ & Variação \% \\
Alumina (1.000 toneladas) & 2886,1 & 3.098 & 7,32 \\
Energia Elétrica (GWh) & 22939,6 & 23.974 & 4,51 \\
Óleo Combustivel (1.000 toneladas) & 59,1 & 54 & $-8,29$ \\
Coque (1.000 toneladas) & 556,2 & 602 & 8,18 \\
Piche (1.000 toneladas) & 172,5 & 184 & 6,55 \\
Fluoreto (1.000 toneladas) & 27,6 & 32 & 16,30 \\
Criolita (1.000 toneladas) & 9,4 & 10 & 1,06
\end{tabular}

Tabela 17 - Insumos para a produção de 1ton de Alumínio Primário (ABAL, Anuário Estatístico 2006)

O consumo específico apresentado no Brasil, no ano de 2006, para a produção de alumínio primário segue a tendência Mundial, que é aproximadamente $14.900 \mathrm{kWh}$ por tonelada. Porém, se considerarmos a média dos últimos dez anos, pode-se destacar uma maior eficiência no consumo específico da indústria nacional, são 15.000 kWh de consumo de energia por tonelada de alumínio contra $15.300 \mathrm{kWh}$ por tonelada na média mundial. 


\section{A ENERGIA ELÉTRICA NO BRASIL}

\subsubsection{RISCOS NO SUPRIMENTO DE ENERGIA ELÉTRICA}

A indústria eletrointensiva tem excessiva preocupação com a segurança e qualidade no fornecimento de energia elétrica no Brasil.

Os riscos de falta no suprimento, como os apresentados no período do racionamento em 2001, são diretamente proporcionais à estratégia de investimentos em ampliação de produção da indústria do alumínio.

Apesar da grande consciência tomada pela população de que a energia elétrica é um insumo de suma importância, já que toda a população, comércio e indústria foram obrigados a racionar energia no ano de 2001, integradas com a atual conscientização de preservação ao meio ambiente, sustentabilidade e preocupação com o aquecimento global, que hoje estão na mídia, a existência de uma possibilidade de um novo racionamento entre 2010 e 2012 assusta os investidores, principalmente os eletrointensivos.

Para provar o problema da falta de energia, verificamos através do gráfico 13, comparado com o gráfico 14, que em 2011 o consumo de energia estará maior que a oferta. 


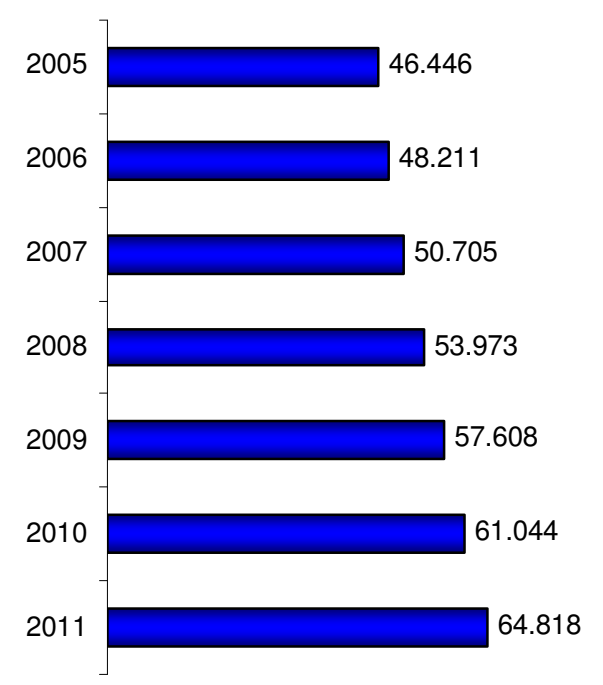

Gráfico 13 - Projeção de Consumo de Energia - MW médios (Jornal Valor Econômico, São Paulo, 30 out. 2007, Caderno Especial).

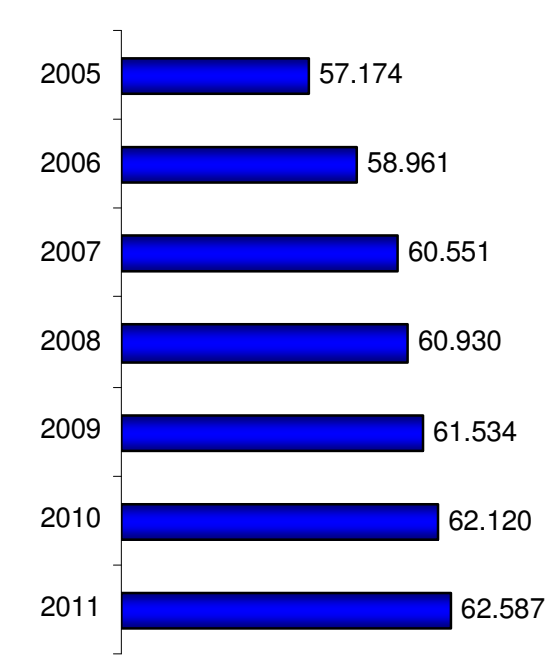

Gráfico 14 - Projeção de Oferta de Energia - MW médios (Jornal Valor Econômico, São Paulo, 30 out. 2007, Caderno Especial).

Segundo o Jornal Valor Econômico, o abastecimento e aumento de preços de energia preocupam os empresários, que prevêem perda de competitividade brasileira no mercado internacional. (Jornal Valor Econômico, São Paulo, 30 out. 2007, Caderno Especial) 
Estudos da FGV Projetos apontam um aumento dos preços da energia elétrica que elevarão os custos de produção das indústrias eletrointensivas, cujos produtos vendidos no exterior perderão competitividade e, assim, poderá haver redução nas exportações.

Para se ter uma idéia da evolução extorsiva dos preços e tributos sobre a energia, em 2003, das doze fábricas da Gerdau no mundo, nove tinham seus custos de energia mais competitivos que as do Brasil. Atualmente, apenas duas fábricas da Gerdau se encontram no Brasil.

O custo da energia na cadeia produtiva do alumínio, que representa em média de $35 \%$ a $40 \%$ do custo final do produto bruto, demanda um alto grau de risco para a saúde desse tipo de indústria.

Devido a todos esses fatores de risco, na maioria delas, as indústrias de alumínio, bem como outros produtores eletrointensivos, têm como principal estratégia, visando minimizar a alta volatilidade apresentada atualmente nos preços da energia, a aquisição de concessões de usinas hidrelétricas, e participação em consórcios ou Sociedade de Propósito Específico (SPE's), como estratégia para diminuir seus custos com esse insumo.

Este tipo de investimento é denominado autoprodução. 


\subsubsection{AUTOPRODUCCÃO COMO ESTRATÉGIA}

Para poder se manter competitiva e manter seu crescimento econômico e produtivo, o setor da indústria de alumínio espera investimentos que adicionem $10.000 \mathrm{GWh}$ até o ano de 2015.

A estratégia de investir em autoprodução não é nova, na década de 40 , a Alcan impulsionou o crescimento da indústria de alumínio no Brasil com a construção de usinas para o abastecimento de sua fábrica, seguindo sua bem sucedida experiência no Canadá.

A CBA foi outra empresa que desde o início investiu em usinas para alimentar sua fábrica localizada na cidade de Alumínio, interior do estado de São Paulo, estratégia esta que a empresa mantém até hoje.

No ano de 2000, a proporção de autoprodução na matriz energética da indústria de alumínio era de $12 \%$. Com a tendência de alta nos preços de energia, aumentaram os investimentos e, em 2007, a participação saltou para $27 \%$, com perspectivas de crescimentos maiores para os próximos anos.

Para comprovar a importância das empresas autoprodutoras de energia no cenário energético nacional, $30 \%$ da energia gerada nas usinas do complexo do rio Madeira serão destinadas às grandes empresas do mercado livre de energia. $O$ governo brasileiro vê, nesse segmento, uma alternativa importante de alavancar investimentos no setor energético do país, evitando, assim, futuros problemas como o ocorrido em 2001.

O cenário de autoprodução no Brasil atualmente está em franca evolução, existem duas usinas em construção, UHE Estreito com 1.087 MW e UHE Serra do Facão com 210 MW, perfazendo um total de 1.297 MW. Em operação existem seis usinas, sendo UHE Candonga com 140 MW, UHE Ourinhos com 44 MW, UHE Piraju com 70 MW, UHE Machadinho com 1.140 MW, UHE Barra Grande com 690 MW e UHE Campos Novos com 880 MW, perfazendo um total de 2.964 
MW, além das usinas que são ligadas diretamente à carga, isto é, que não fazem parte da Rede Básica.

Devido a problemas, principalmente na tentativa de obtenção de licenças ambientais, algumas usinas ainda não começaram sua construção; dentre elas estão a UHE Serra Quebrada com 1.328 MW, a UHE Santa Isabel com 1.087 MW e a UHE Pai Querê com 290 MW, perfazendo um total de 2.705 MW a ser adicionado ao Sistema Brasileiro.

A Figura 12, a seguir, ilustra a localidade e potência de cada usina do sistema dos autoprodutores de energia.

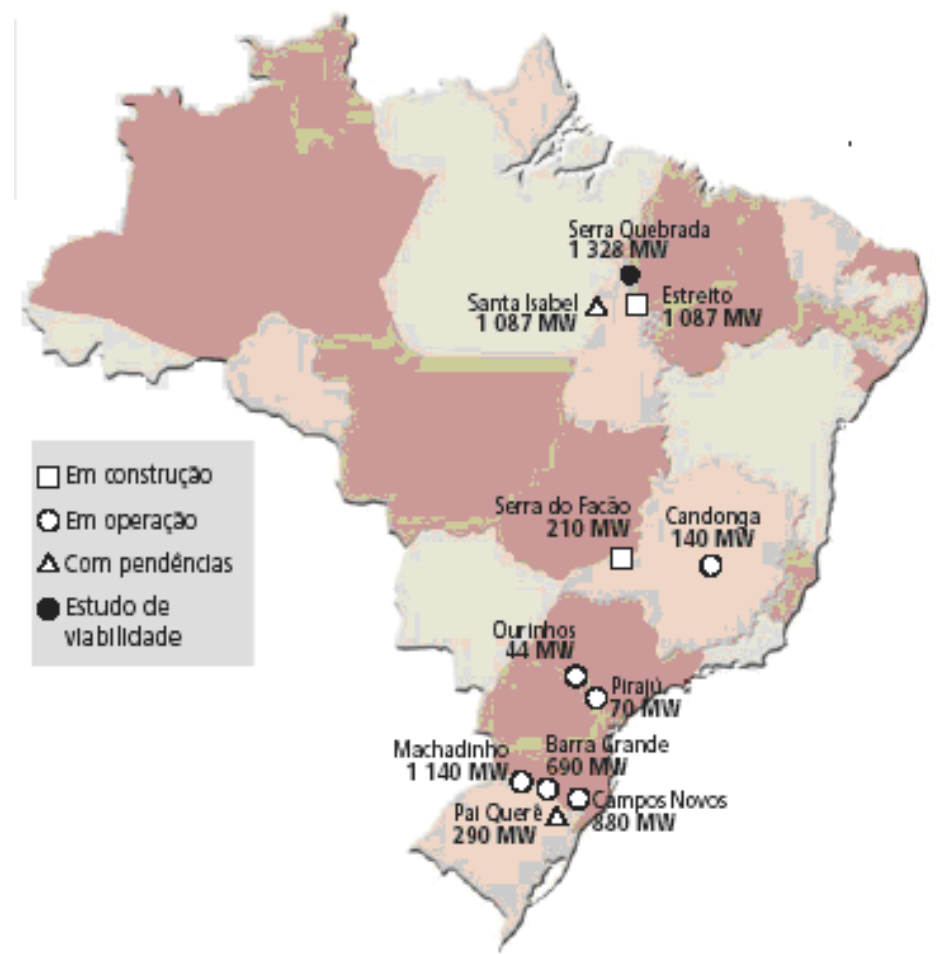

Figura 12 - Localização das Usinas dos Autoprodutores (ABAL, 2006)

Visando diminuir os custos de energia, incentivando as indústrias eletrointensivas a investir em autoprodução, a Lei $\mathrm{n}^{\circ} 11.488$, de 15 de junho de 2007, em seu artigo 26, equipara a autoprodutor o consumidor que atenda cumulativamente aos seguintes requisitos: 
I- que venha a participar de Sociedade de Propósito Específico-SPE constituída para explorar, mediante autorização ou concessão, a produção de energia elétrica;

II - que a sociedade inicie a operação comercial a partir da data de publicação da Lei; e

III - que a energia elétrica produzida no empreendimento deva ser destinada, no todo ou em parte, para seu uso exclusivo.

A mencionada equiparação é destinada à isenção de alguns encargos que incidem sobre comercialização de energia, quais sejam, Conta de Desenvolvimento Energético - CDE, Programa de Incentivo de Fontes Alternativas - PROINFA e a Conta de Consumo de Combustíveis Fósseis dos Sistemas Isolados - CCC-ISOL. Trata-se, portanto, do reconhecimento da parcela de autoprodução em SPE que, de maneira equivocada pelo arcabouço jurídico e

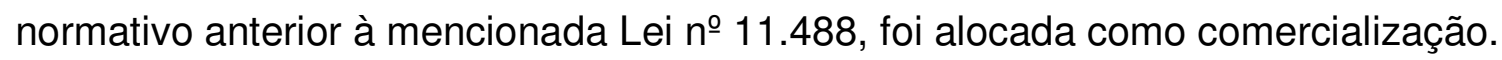

O parágrafo $2^{\circ}$ da citada Lei diz que "a regulamentação deverá estabelecer, para fins de equiparação, montantes mínimos de demanda por unidade de consumo".

Nesse sentido, o Decreto ํㅡ 6.210, de 18 de setembro de 2007, no seu artigo $2^{\circ}$ estabeleceu que "para fins da equiparação de que trata o artigo 26 da Lei no 11.488, de 15 de junho de 2007, cada unidade de consumo a que se destina a energia elétrica proveniente de Sociedade de Propósito Específico deverá ter demanda de potência igual ou superior a 3.000 kW".

Uma das alternativas poderia ser a usina ligada diretamente à fábrica, porém cabe destacar que somente é possível se estes, usina e fábrica, incluindo a linha de transmissão de conexão, estiverem em sítios de mesma titularidade e mediante aprovação da ANEEL, conforme podemos observar no Artigo 71 do Decreto $n^{\circ}$ 5.163, de 30 de julho de 2004, em especial nos parágrafos $7^{\circ}$ e $8^{\circ}$, descritos a seguir. 
"Art. 71. Conforme disciplina a ser emitida pela ANEEL até outubro de 2005, as concessionárias de serviços públicos de distribuição deverão incorporar a seus patrimônios as redes particulares de energia elétrica que não dispuserem de ato autorizativo do poder concedente até 31 de dezembro de $2005 \mathrm{ou}$, mesmo dispondo, desde que exista interesse das partes em que sejam transferidas.

$\S 1^{\circ}$ Considera-se, para fins do disposto no caput, rede particular a instalação elétrica, em qualquer tensão, utilizada para o fim exclusivo de prover energia elétrica para unidades de consumo de seus proprietários e conectada em sistema de transmissão ou de distribuição de energia elétrica.

$\S 2^{\circ}$ As concessionárias de serviços públicos de transmissão e de distribuição de energia elétrica deverão cientificar, até 30 de novembro de 2004, os proprietários de redes particulares conectadas a seus respectivos sistemas sobre o disposto no art. 15 da Lei no 10.848 , de 2004, neste artigo e no ato da ANEEL que disciplinar a matéria.

$\S 3^{\circ}$ O proprietário de rede particular já instalada que não dispuser de ato autorizativo do poder concedente poderá requerê-lo até 30 de outubro de 2005, apresentando as informações e documentos que forem exigidos pela ANEEL, incluindo a comprovação da titularidade sobre os imóveis em que se situa a rede particular, ou da respectiva autorização de passagem.

$\S 4^{\circ}$ A ANEEL deverá expedir o ato autorizativo de que trata o $\S 3^{\circ}$ até 31 de dezembro de 2005, desde que atendidas as condições requeridas para sua expedição.

$\S 5^{\circ}$ A partir de 10 de janeiro de 2006 , as redes particulares que não dispuserem de ato autorizativo serão incorporadas ao patrimônio das concessionárias de serviços públicos de distribuição de energia elétrica, conforme as respectivas áreas de concessão, mediante processo formal a ser disciplinado pela ANEEL, observadas as seguintes condições: 
I - comprovação pela concessionária do cumprimento do disposto no $\S 2^{\circ}$; e

II - avaliação prévia das instalações, para o fim de fixação do valor a ser indenizado ao titular da rede particular a ser incorporada.

$\S 6^{\circ}$ Os custos decorrentes da incorporação de que trata $0 \S 5^{\circ}$, incluindo a reforma das redes, após aprovação pela ANEEL, serão considerados nos processos de revisão tarifária da concessionária incorporadora.

$\S 7^{\circ}$ Não serão objeto da incorporação de que trata o $\S 5^{\circ}$ deste artigo as redes, em qualquer tensão, de interesse exclusivo de agentes geradores que conectem suas instalações de geração à rede básica, à rede de distribuição, ou a suas instalações de consumo, desde que integrantes das respectivas concessões, permissões ou autorizações.

$\S 8^{\circ}$ As redes particulares instaladas exclusivamente em imóveis de seus proprietários não serão objeto de ato autorizativo ou de incorporação, salvo, neste último caso, se houver expresso acordo entre as partes. (Redação dada pelo Decreto ํㅜ 5.597, de 2005)" 


\section{O MERCADO DE ENERGIA NO BRASIL}

\subsection{INTRODUÇÃO}

Durante a década de 90 quase todas as empresas de energia do Brasil foram privatizadas, um sistema elétrico que era do estado passou a ter empresas privadas no comando, com isso, a ânsia por resultados, lucros, e com uma visão social, passou a ser capital.

Para que essa transição se desse de maneira sustentável, fez-se necessário criar uma agência reguladora, a Agência Nacional de Energia Elétrica, ANEEL, responsável pelas atuais regras e modelo do setor elétrico brasileiro.

Após a criação da ANEEL, e com o objetivo de promover a competitividade e desenvolvimento do setor elétrico, foram criadas duas empresas sem fins lucrativos, conforme segue:

- Operador Nacional do Sistema, ONS, criado através da Lei 9.649 de 27 de maio de 1998, e regulamentado pelo Decreto n. 2.655 de 02 de julho de 1998 , com as alterações do Decreto n. 5.081 , de 14 de maio de 2004, que define sua principal responsabilidade no Art. $1^{\circ}$ transcrito abaixo:

Art. 1․ - O Operador Nacional do Sistema Elétrico - ONS, pessoa jurídica de direito privado, sem fins lucrativos, fica autorizado, nos termos do art. 13 da Lei $n^{\circ}$ 9.648, de 27 de maio de 1998, a executar as atividades de coordenação e controle da operação, da geração e da transmissão de energia elétrica do Sistema Interligado Nacional - SIN, sob a fiscalização e regulação da Agência Nacional de Energia Elétrica - ANEEL.

- Mercado Atacadista de Energia Elétrica, MAE, regulamentado através do Decreto $n^{\circ} 2.655$ de 02 de julho de 1998, regulamenta o Mercado Atacadista de Energia Elétrica, MAE, responsável por gerir as transações de compra e venda de energia no sistema interligado nacional, além de criar os procedimentos e regras de mercado, como, obrigações para vender e comprar toda a disponibilidade de energia gerada, procedimentos de adesão ao MAE, contabilização e liquidação 
financeira, registro dos contratos bilaterais, requisitos de garantia financeira, mediações entre agentes membros, entre outros.

Porém, o sucesso do modelo esbarrou no racionamento ocorrido em 2001, e uma série de mudanças de diretrizes teve que acontecer, principalmente no tocante à manutenção dos recursos hidrológicos, visando um melhor aproveitamento do regime hidrotérmico nacional, mitigando nova possibilidade de falta de energia.

Neste capítulo, será abordado o novo setor energético brasileiro, e qual a influência do mesmo na indústria eletrointensiva, no tocante à indústria de alumínio.

\subsection{SISTEMA ISOLADO}

Os Sistemas Isolados do Brasil têm como característica serem predominantemente térmicos, e estão localizados na região Norte do País. Têm uma capacidade instalada de $3.027 \mathrm{MW}$, cerca de $3,3 \%$ da capacidade instalada do Brasil, importam cerca de 200MW de energia advindas da Venezuela, e têm um total de linhas de transmissão de $1.448 \mathrm{~km}$ correspondendo a 1,7\% do total de linhas de transmissão do Brasil.

Os Sistemas Isolados atendem a uma área de $45 \%$ do território, como podemos identificar na Figura 13, e apenas cerca de $3 \%$ da população brasileira, aproximadamente 1,2 milhão de consumidores. 


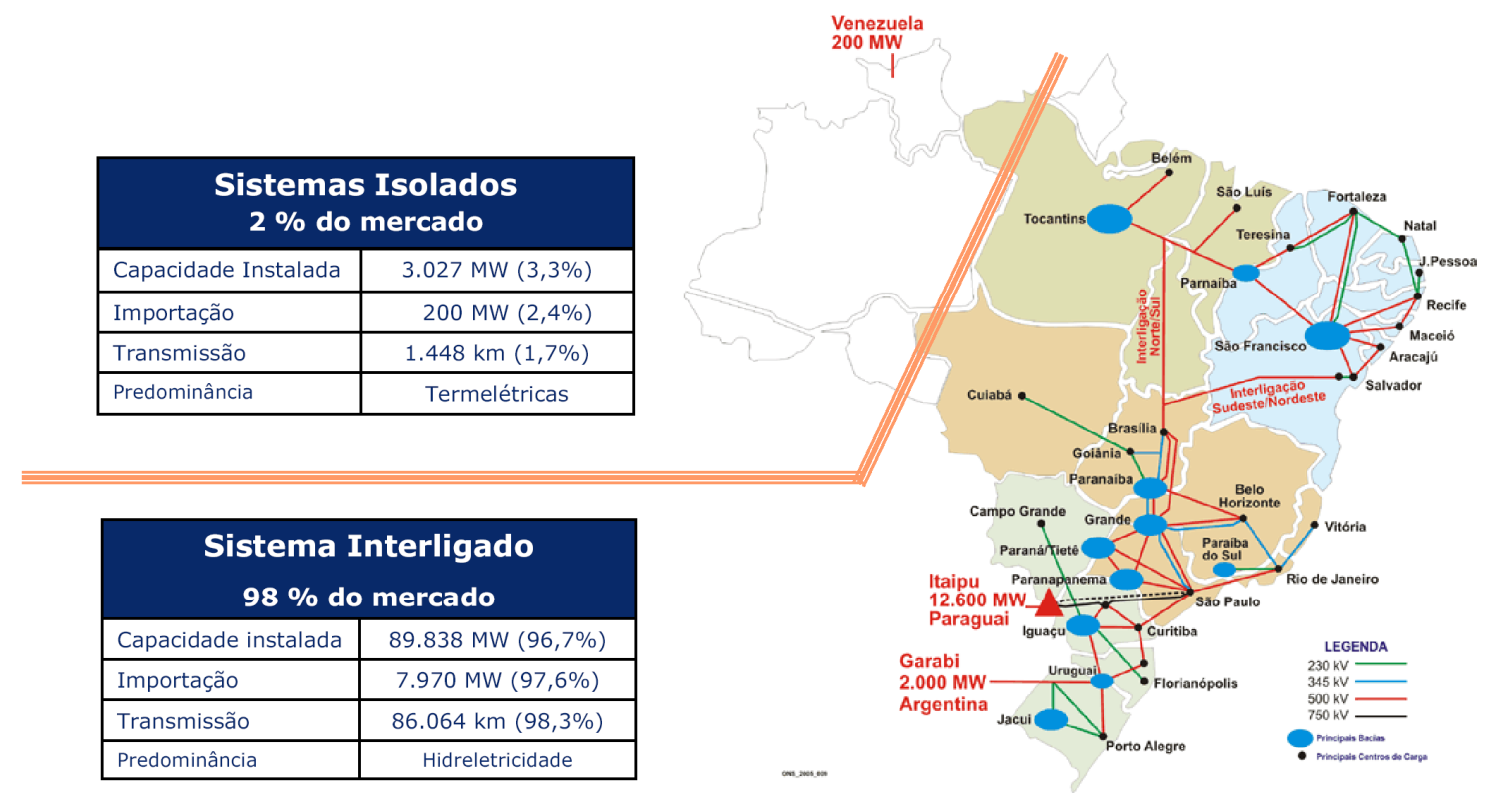

Figura 13 - Sistema de Transmissão Brasileiro (CCEE, 2007)

As empresas que atendem os Sistemas Isolados são: CEAM - Companhia Energética do Amazonas, que atende o estado do Amazonas; ELETROACRE Companhia de Eletricidade do Acre, que atende o estado do Acre; CEMAT Centrais Elétricas Matogrossenses, que atende o estado do Mato Grosso; CERON - Centrais Elétricas de Rondônia, que atende o estado de Rondônia; CEA Companhia de Eletricidade do Amapá, que atende o estado do Amapá; CER Companhia Energética de Roraima, que atende o estado de Roraima; e CELPA Centrais Elétricas do Pará, que atende o estado do Pará.

As cidades do interior dos estados da região Norte são predominantemente atendidas por pequenas centrais termelétricas a óleo diesel.

A coordenação de operação e planejamento dos Sistemas Isolados é feita pelo GTON - Grupo Técnico Operacional da região Norte, criado através da portaria MINFRA $n^{\circ}$ 895, de 29 de novembro de 1990, e tem como objetivo 
assegurar aos consumidores as mesmas vantagens de segurança, qualidade $\mathrm{e}$ confiabilidade dos consumidores do Sistema Interligado.

De acordo com o Ciclo de Planejamento 2006, elaborado pela equipe do GTON, até o ano de 2016, uma parcela do Sistema Isolado será incorporada ao Sistema Interligado Nacional, que compreendem os sistemas Acre/Rondônia, através do Mato Grosso, e o Sistema Manaus, Amapá, margem esquerda do Amazonas, contemplando as localidades do interior do Amazonas e do Pará.

As parcelas previstas a integrar o Sistema Interligado, de acordo com o relatório do Ciclo de Planejamento 2006 dos Sistemas Isolados, correspondem a $84 \%$ de todo Sistema Isolado, sendo $57 \%$ interligado ao submercado Norte, e $26 \%$ ao submercado Sudeste/Centro-oeste.

Após as interligações, a parcela de carga que restará ao Sistema Isolado será menor que $1 \%$ do total da carga do país.

\subsection{SISTEMA INTERLIGADO}

O Brasil é um país com características continentais, o que o faz único; seu sistema de transmissão de energia elétrica tem a capacidade de transportar grandes quantidades em grandes distâncias.

O Sistema Interligado Nacional, SIN, atende às regiões Sul, Sudeste, Nordeste e parte do Norte. De acordo com o ONS, 3,3\% da capacidade de produção de eletricidade do país encontra-se fora do SIN, em pequenos sistemas isolados, localizados predominantemente na região Amazônica. 


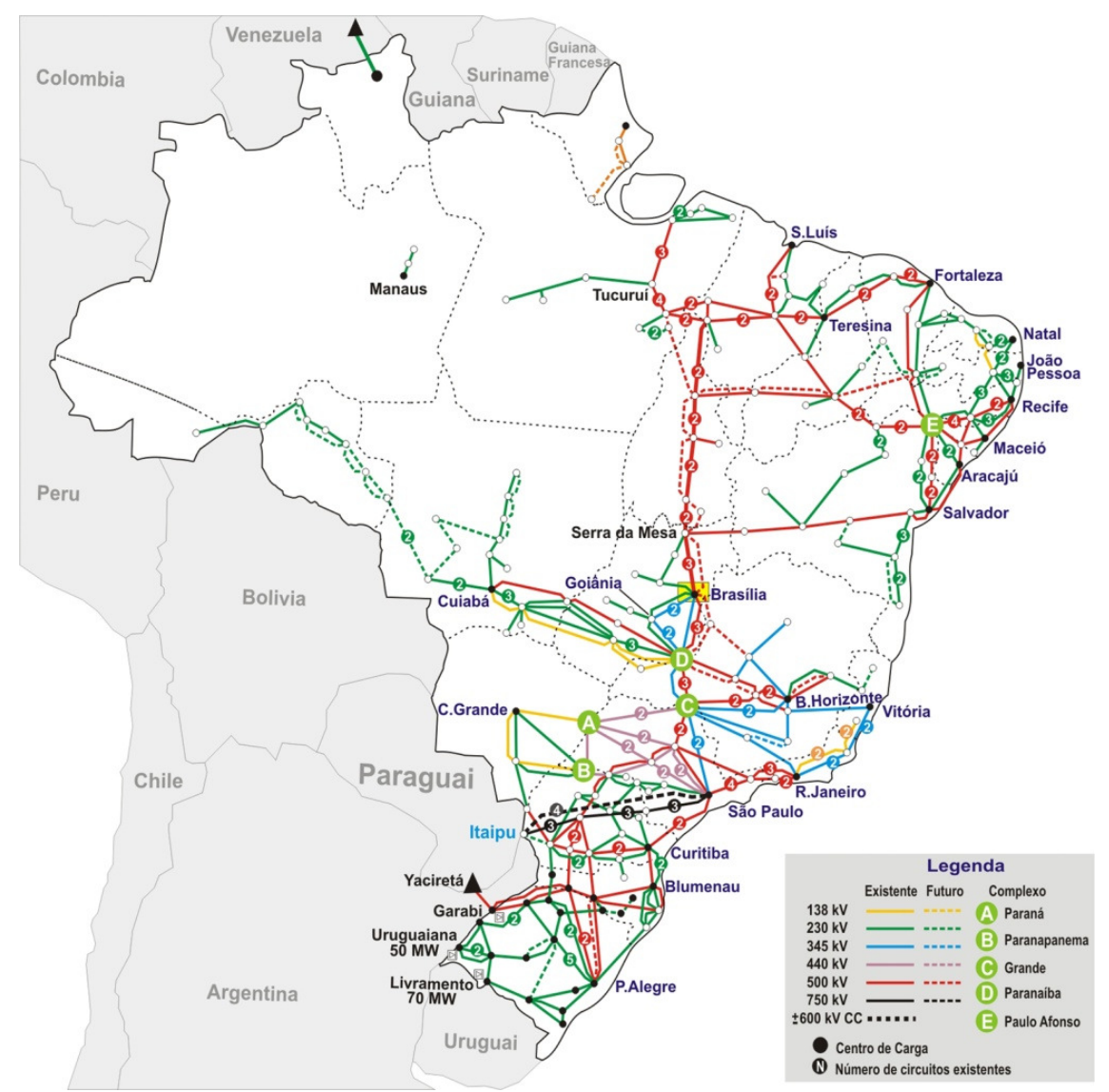

Figura 14 - Sistema Interligado Nacional $\left(\mathrm{ONS}^{3}, 2007\right)$

A responsabilidade da operação do SIN, bem como despacho das usinas, fica ao encargo do Operador Nacional do Sistema (ONS).

Atualmente, de acordo com informações colhidas do site da $\mathrm{ANEEL}^{4}$, o Brasil possui uma malha de transmissão de energia de $83.947,216 \mathrm{~km}$, que estão em operação e fazem parte do Sistema Interligado Nacional.

Através do Gráfico 15, a seguir, é possível notar que o acréscimo anual de linhas de transmissão se intensificou com a entrada da ANEEL em 1998, que por meio da Empresa de Pesquisa Energética (EPE) elabora os estudos das necessidades de ampliação da rede de transmissão e promove licitações para empresas privadas interessadas na construção da mesma.

(3) http://www.ons.org.br; acesso em 22/11/2007

(4) http://www.aneel.org.br; acesso em 22/11/2007 
Para o ano de 2008, a ANEEL prevê a entrada de mais de $5.700 \mathrm{~km}$ de linhas de transmissão.

(em km)

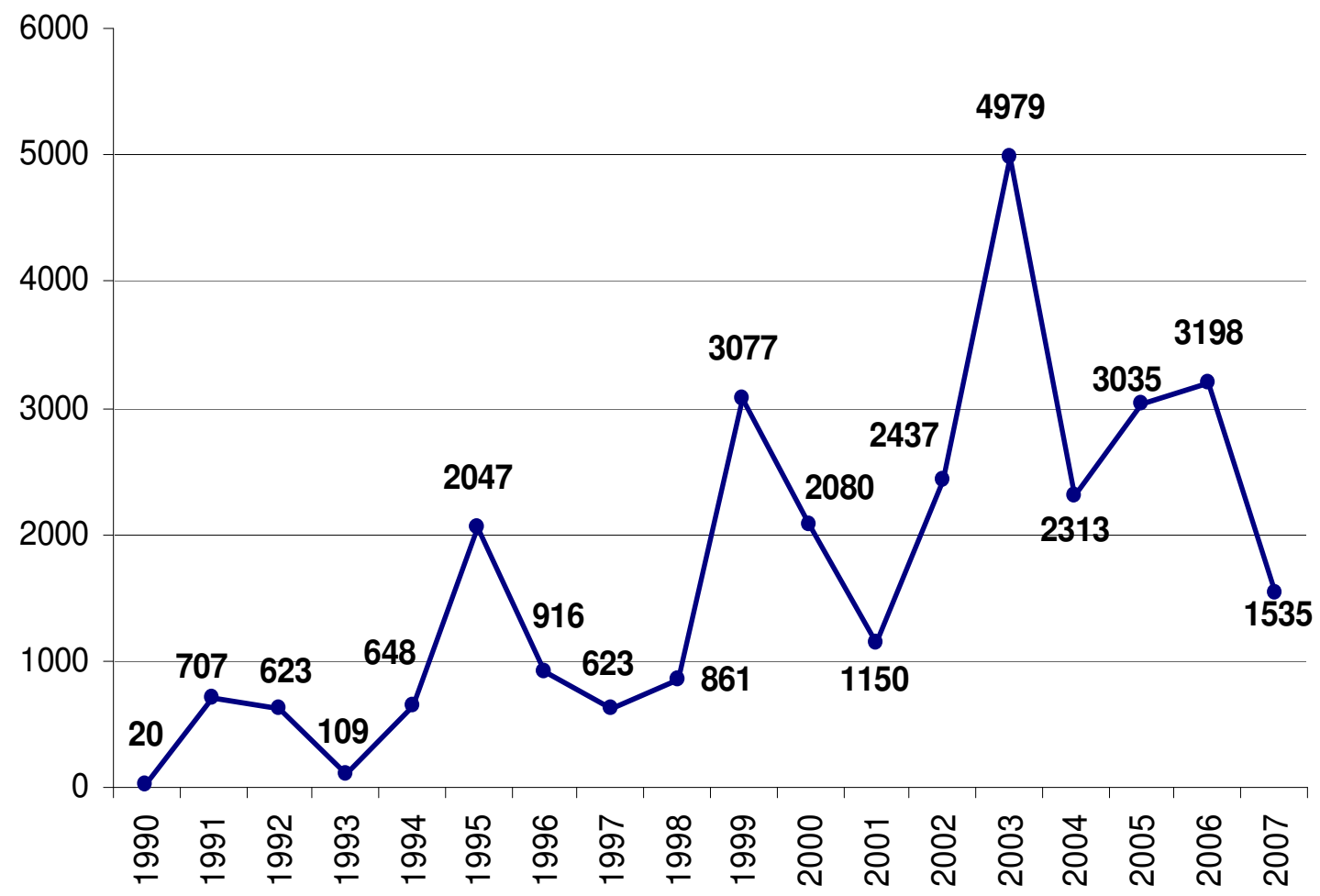

Gráfico 15 - Acréscimo anual de linhas de transmissão (ONS, 2007)

O Sistema Interligado Nacional é composto por linhas de transmissão e subestações de energia com tensão igual ou superior a $230 \mathrm{kV}$, este conjunto é denominado Rede Básica.

O acesso à Rede Básica é livre, quaisquer agentes produtores, distribuidores ou consumidores de energia têm o direito de acesso, desde que atendidas as exigências técnicas e legais. O acesso do consumidor livre é assegurado pelo artigo 15으 da Lei $\mathrm{n}^{\circ} 9074$ de 1995.

Lei no 9.074/95, art. 15 - "É assegurado aos fornecedores e respectivos consumidores livres acesso aos sistemas de distribuição e transmissão de concessionário e permissionário de serviço público, mediante ressarcimento do custo de transporte envolvido, calculado com base em critérios fixados pelo Poder Concedente." 
O direito ao livre acesso faz parte da reestruturação do setor elétrico nacional, concedendo maior liberdade ao setor, com intuito de uma maior competitividade e sustentabilidade.

Porém, o livre acesso está condicionado à solicitação e posterior avaliação, com estudo das influências das cargas ou geração, no ponto de conexão e no sistema, indicando a conseqüência aos demais usuários, e que garanta o fornecimento com maior qualidade e confiabilidade possível.

Para os consumidores livres que pretendem acessar a Rede Básica, o Decreto 5597, de 2005, preconiza as seguintes formas:

1) por meio de concessionárias de distribuição locais;

2) por meio de concessionárias de transmissão locais; e

3) mediante construção do próprio acesso.

Todos os procedimentos para o acesso, bem como a avaliação dos estudos realizados, são efetuados pelo ONS, regidos pelos Procedimentos de Rede, que são documentos auxiliares que definem procedimentos e regulamentos técnicos de uso e operação do SIN, bem como os direitos e deveres do ONS, consumidores livres, distribuidores e transmissoras.

Os usuários da Rede Básica têm como obrigação firmar um Contrato de Uso dos Sistemas de Transmissão (CUST), com o ONS, que estabelecem as regras e condições técnicas do uso das instalações de transmissão.

Para o acesso à Rede Básica se faz necessário também firmar o Contrato de Conexão à Transmissão (CCT) com a concessionária de transmissão local, que visa estabelecer as responsabilidades pela implantação, operação e manutenção das instalações de conexões, subestações, e respectivos encargos. 


\subsubsection{Classificações de Transmissão}

As instalações de transmissão de energia podem ser subdivididas basicamente em três classes: as instalações destinadas a atender a Rede Básica com tensão superior ou igual a $230 \mathrm{kV}$; as instalações de transmissão destinadas à distribuição de energia; e as linhas de transmissão de exclusividade dos geradores e consumidores livres de energia.

As linhas de transmissão da Rede Básica e atividades referentes à distribuição de energia são destinadas a prestação de serviço público, tendo suas tarifas reguladas pela ANEEL, já as demais linhas de transmissão utilizadas por geradores e consumidores livres têm como característica a necessidade de solicitação de acesso, através de estudos de impactos energéticos.

As instalações de transmissão com tensão inferior a $230 \mathrm{kV}$, localizadas dentro da área de uma distribuidora, sendo uma empresa transmissora a proprietária, são denominadas Demais Instalações de Transmissão (DIT's), que têm como características não pertencerem à Rede Básica.

As instalações acima de 230kV são divididas de acordo com o estabelecido na Resolução número 67, de 2004, da ANEEL: a Rede Básica que contempla todas as linhas de transmissão com tensão igual ou superior a $230 \mathrm{kV}$; e a Rede Básica de Fronteira, que contempla as instalações de fronteira, que são as subestações e seus equipamentos.

A Rede Básica, a Rede Básica de Fronteira e as DIT's são remuneradas através de cálculos de tarifas proporcionais à demanda de energia no ponto de conexão da carga ou geração.

O acesso à Rede Básica é feito por três características distintas de agentes: concessionárias de serviços públicos de distribuição de energia elétrica; geradores de energia, em suas maiorias hidrelétricas e termelétricas; e 
consumidores livres, geralmente grandes empresas eletrointensivas, característica da indústria de alumínio.

\subsubsection{Tarifas de Transmissão e Encargos}

\subsubsection{Tarifa de Uso do Sistema de Transmissão}

O ONS tem como obrigação, não somente comandar a operação do sistema elétrico brasileiro, como também responder pela administração da remuneração dos agentes de transmissão.

Uma das tarifas do sistema de transmissão é denominada TUST (Tarifa de Uso do Sistema de Transmissão). Ela tem como objetivo remunerar as concessionárias de transmissão de energia.

A TUST é calculada utilizando o método nodal, que tem como objetivo apresentar um sinal econômico locacional, conforme preconizado em lei, e é dividida em duas parcelas: a TUST-FR e a TUST-RB.

A TUST-FR, de acordo com a Resolução Normativa № 067, de 8 de junho de 2004, inclui a remuneração por outros ativos da transmissora, como as subestações de transformação de tensão igual ou superior a $230 \mathrm{kV}$, e as Demais Instalações de Transmissão - DIT's. A TUST-FR é paga somente pelas concessionárias de serviços de distribuição de energia elétrica.

A outra parcela que compõe a TUST, a TUST-RB, tem como origem o valor total, durante o período de um ano, necessário para remuneração de todas as instalações que compõem a Rede Básica, além de alguns parâmetros estabelecidos na Resolução no 117, de 2004. O método utilizado como forma de exprimir esse valor em tarifas aos agentes conectados à Rede Básica é o método Nodal, que utiliza como dados de entrada a configuração da rede, representada por suas linhas de transmissão, subestações, geração e carga. 
O valor total da TUST-RB é basicamente a soma da Receita Anual Permitida (RAP) definida pela ANEEL, o valor da contribuição dos serviços do ONS, e o valor destinado a novas obras, além de ajustes do ano anterior.

O valor total da TUST é rateado entre todos os agentes conectados ao sistema de transmissão, como centrais geradoras, consumidores livres, concessionárias de distribuição e agentes de importação ou exportação de energia elétrica.

No tocante ao tema deste trabalho, os Autoprodutores, bem como os consumidores livres conectados à Rede Básica, incorporam em sua tarifa, além da TUST-RB, mais três encargos setoriais, expresso em $\mathrm{R} \$ / \mathrm{MWh}$; a Conta de Consumo de Combustíveis - CCC, a Conta de Desenvolvimento Energético $\mathrm{CDE}$, e o Programa de Incentivo às Fontes Alternativas de Energia Elétrica PROINFA. Essas tarifas são dispostas no Anexo II da REH no 497/2007.

Os agentes de geração conectados às Demais Instalações de Transmissão - DIT's possuem diferente encargo de conexão, que é a Tarifa de Uso do Sistema de Distribuição de Geração - TUSDg, conforme previsto no Anexo IV da Resolução 497/2007 da ANEEL, porém está em Audiência Pública a alteração desta tarifa pelo entendimento de não ser a melhor forma de custeio de tais encargos.

\subsubsection{Programa de Incentivo às Fontes Alternativas de Energia Elétrica}

O Programa de Incentivo às Fontes Alternativas de Energia Elétrica PROINFA - foi criado em 2002, instituído pela lei no 10.438, de 26 de abril de 2002, e tem como objetivo aumentar a participação de fontes alternativas renováveis na produção de energia elétrica no país, tais como: energia eólica, biomassa e pequenas centrais hidrelétricas. 
Anualmente, são divulgadas pela ANEEL as cotas anuais de energia e o rateio do custo a serem pagas por todos os agentes conectados ao SIN, que comercializam energia com o consumidor final, ou utilizam a rede de distribuição, isto é, todos os consumidores de energia que estão ligados direta ou indiretamente ao SIN, excluindo os consumidores classificados como residencial de baixa renda, com consumo inferior a $80 \mathrm{kWh} / \mathrm{mês}$.

A compra da energia produzida pelos geradores cadastrados no PROINFA é garantida pela Centrais Elétricas Brasileiras S.A. - ELETROBRÁS, assegurada por 15 anos após entrada em operação, e seu valor não pode ultrapassar um piso, definido como $80 \%$ da tarifa média nacional de fornecimento ao consumidor final.

Como o valor definido é insuficiente para cobrir os custos destes geradores, é dado ao produtor um crédito complementar oriundo da Conta de Desenvolvimento Energético - CDE, calculado pela diferença entre o valor econômico específico de cada fonte, a ser definido pelo Poder Executivo, mas sempre respeitando o piso definido na primeira etapa, e o valor recebido da ELETROBRÁS.

Os valores de tarifas, bem como as quotas de energia para cada consumidor livre, autoprodutores e concessionárias de distribuição, é definida anualmente, sendo que a atual tarifa e quota de energia foi definida pela Resolução Normativa $n^{\circ}$ 567, de 27 de novembro de 2007, através do Artigo 1ํㅡ, Parágrafo Único, abaixo transcrito:

Parágrafo único. Fica estabelecido, para os fins desta Resolução, o valor unitário do PROINFA, em $R \$ 2,59 / \mathrm{MWh}$, que acrescido dos tributos Programa de Integração Social - PIS e Contribuição para o Financiamento da Seguridade Social - COFINS, resulta na Tarifa de Uso do Sistema de Transmissão - TUST PROINFA, no valor de R\$ 2,85/MWh.

As cotas de energia estão dispostas no anexo da Resolução supra citada. 


\subsubsection{Conta de Desenvolvimento Energético}

Com a publicação da Lei 10.438, de 26 de abril de 2002, foi criada a Conta de Desenvolvimento Energético - CDE, que tem como principais objetivos o desenvolvimento energético dos estados, subsidiar a competitividade da energia produzida por fontes alternativas, tais como, eólica, biomassa, Pequenas Centrais Hidrelétricas, gás natural e carvão mineral nacional, e também promover a universalização da distribuição de energia elétrica por todo país.

De acordo com a Lei 10.438/02, Artigo 13ำ, parágrafo 1ํ, "Os recursos da CDE serão provenientes dos pagamentos anuais realizados a título de uso de bem público, das multas aplicadas pela ANEEL a concessionários, permissionários e autorizados e, a partir do ano de 2003, das quotas anuais pagas por todos os agentes que comercializem energia com o consumidor final.". Esses valores tiveram como base os custos estabelecidos para a Conta de Consumo de Combustíveis do Sistema Interligado - CCCINTERLIGADO do ano de 2001, e são reajustadas anualmente, conforme Parágrafo $3^{\circ}$, na proporção do crescimento do mercado de cada agente, até o limite que não cause incremento tarifário para o consumidor.

A CDE tem período de vigência de 25 (vinte e cinco) anos, e é regulamentada pelo Poder Executivo, e movimentada pela ELETROBRÁS.

As tarifas da CDE são diferentes para cada região do Brasil, para as regiões Sul, Sudeste e Centro-Oeste, o valor da tarifa é de $R \$ 10,00 / \mathrm{MWh}$, e para as regiões Norte e Nordeste, o valor da tarifa é $R \$ 2,10$ / MWh, sendo que para ambos os casos, já estão incluídos no valor da tarifa os tributos de PIS/COFINS.

As tarifas da CDE mencionadas foram publicadas na Resolução Homologatória $n^{\circ} 671$, de 24 de junho de 2008. 


\subsubsection{Conta de Consumo de Combustíveis Fósseis}

A Conta de Consumo de Combustíveis Fósseis (CCC) foi criada em 05 de

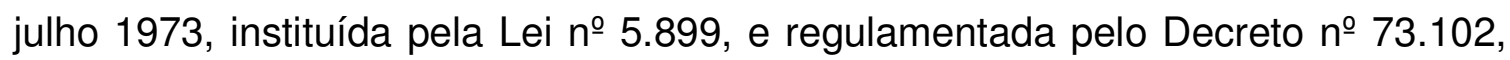
de 07 de novembro de 1973, inicialmente aplicada apenas às regiões Sul, Sudeste e Centro-Oeste e posteriormente em todo o Brasil.

A CCC tem como objetivo financiar os custos de geração de energia termelétrica com base em combustíveis fósseis nos Sistemas Interligados e, principalmente, nos Sistemas Isolados.

O subsídio da CCC permite que os consumidores localizados nos Sistemas Isolados tenham tarifas mais justas, alinhadas com as tarifas praticadas no restante do país.

Através da Lei no 8.631, de 04 de março de 1993, regulamentada pelo Decreto no 774, de 18 de março de 1993, a CCC foi desdobrada em três subcontas, a CCC - Norte/Nordeste, CCC - Sul/Sudeste/Centro-Oeste, e CCC Sistemas Isolados, e estabelecidos critérios para o rateio dos custos.

O benefício da CCC foi estendido às Pequenas Centrais Hidrelétricas, e empreendimentos de geração a partir de fontes alternativas, em 27 de maio de 1998, através da Lei ํo 9.631 .

A CCC teve seu período de vigência estendido por mais 20 anos, com a publicação da Lei no 10.438/02, que alterou o Art. 11ํ da Lei no 9.648/98, e incorporou o direito de uso da geração de energia elétrica a partir de gás natural.

Cabe à ELETROBRÁS a gestão dos recursos provenientes da CCC, sendo que o rateio do encargo é realizado entre as distribuidoras e transmissoras, que, por sua vez, repassam estes custos ao consumidor.

No caso dos consumidores livres conectados à Rede Básica de transmissão, o valor do encargo do CCC-Sistema Isolado é de R\$9,22/MWh, já 
incluídos no valor da tarifa, os tributos de PIS/COFINS, de acordo com o publicado na Resolução Homologatória $n^{\circ}$ 671, de 24 de junho de 2008.

\subsubsection{Taxa de Fiscalização de Serviços de Energia Elétrica}

A Taxa de Fiscalização de Serviços de Energia Elétrica - TFSEE foi instituída por meio dos dispostos nos artigos 11 a 13 da Lei n 9.427, de 26 de dezembro de 1996, e tem como objetivo remunerar a ANEEL para cobrir suas despesas administrativas e operacionais.

A TFSEE é fixada anualmente pela ANEEL e paga em duodécimos por todos os agentes do setor elétrico, tais como, concessionárias de geração e de transmissão de serviço público, autoprodutores, produtores independentes de energia elétrica e consórcios de geração.

A ANEEL fixou o valor da TFSEE, atribuída para os autoprodutores, produtores independentes e consórcios de geração como Benefício Econômico Típico unitário Anual - BETA, para o exercício de 2008, em $\mathrm{R} \$ 303,78 / \mathrm{kW}$ instalado, através da publicação do Despacho $n^{0} 3.731$, de 27 de dezembro de 2007.

\subsubsection{ENERGIA DE RESERVA}

A Energia de Reserva é um instrumento publicado pela ANEEL nos dispositivos da Resolução no 371, de 29 de dezembro de 1999, alterado pela Resolução Normativa ํㅜ 304, de 04 de março de 2008, da ANEEL, em que trata da tarifa sobre a demanda em caso de falhas de geração de uma ou mais unidades geradoras, e na qual a fórmula do cálculo da tarifa e as regras são transcritos no artigo $5^{\circ}$ da resolução citada, conforme a seguir: 
"Art. 50 O valor a ser cobrado nos contratos de reserva de capacidade pelo uso dos sistemas elétricos de transmissão ou distribuição será calculado por meio da seguinte equação:

$$
E_{R C}=\left(M_{P} * T_{P}+M_{f p} * T_{f p}\right) * \frac{n_{u}}{n_{m}}
$$

Onde:

$E_{R C}$ : encargo mensal pelo uso da reserva de capacidade, em $R$;

$\mathrm{n}_{\mathrm{u}}$ : número de dias em que houve utilização da reserva de capacidade no mês em referência;

$\mathrm{n}_{\mathrm{m}}$ : número de dias do mês em referência;

$\mathrm{T}_{\mathrm{p}}$ : tarifa de uso do sistema de transmissão ou de distribuição no horário de ponta para unidades consumidoras, em $R \$ / k W$;

$\mathrm{T}_{\mathrm{fp}}$ : tarifa de uso do sistema de transmissão ou de distribuição no horário fora de ponta, para unidades consumidoras, em $\mathrm{R} \$ / \mathrm{kW}$;

$\mathrm{M}_{\mathrm{p}}$ : montante de uso de reserva de capacidade para o horário de ponta, em kW, determinado pelo maior valor entre o contratado e 0 verificado por medição no mês em referência, devendo o referido valor contratado ser único para todo ciclo contratual;

$\mathrm{M}_{\mathrm{fp}}$ : montante de uso de reserva de capacidade para o horário fora de ponta, em kW, determinado pelo maior valor entre o contratado e o verificado por medição no mês em referência, devendo o referido valor contratado ser único para todo o ciclo contratual.

$\S 1^{\circ} \mathrm{Na}$ hipótese de, em um determinado ciclo contratual, o número acumulado de dias em que houve utilização da reserva de capacidade ultrapassar 60 (sessenta) dias, as tarifas aplicáveis ao cálculo do encargo mensal pelo uso da reserva de capacidade relativo aos dias excedentes serão de valor igual a quatro vezes as tarifas de uso do sistema de transmissão ou de distribuição estabelecidas para os horários de ponta e fora de ponta.

$\S 2^{2}$ Será aplicada à parcela do montante de uso de reserva de capacidade verificada por medição superior ao valor contratado uma 
tarifa de ultrapassagem igual a três vezes o valor aplicável da tarifa de uso do sistema de transmissão ou de distribuição estabelecida para cada período, quando se verificar ultrapassagem superior a $5 \%$ (cinco por cento) do valor contratado, considerando-se $n_{u}=n_{m}$ na equação referenciada no "caput".

\subsubsection{Pesquisa \& Desenvolvimento}

O encargo referente à Pesquisa e Desenvolvimento Energético (P\&D) foi criado pela Lei n.o 9.991, de 24 de julho de 2000, e estabelece que as concessionárias e permissionárias de serviços públicos de distribuição, transmissão e geração de energia elétrica ficam obrigadas a aplicar anualmente o montante $1 \%$ de sua receita operacional líquida no Programa de Pesquisa e Desenvolvimento do Setor de Energia Elétrica.

Os autoprodutores de energia elétrica são isentos da aplicação desses encargos sobre a parcela efetivamente autoproduzida, sendo que os montantes de energia que excederem seu consumo estão sujeitos à cobrança de P\&D.

A aplicação desse encargo, no caso de um agente de geração, é dividida em 3 setores, conforme definido na Lei $n^{0}$ 11.465/2007, que alterou incisos I e III do art. $1^{\circ}$ da 9.991/2000, sendo estes:

- $0,4 \%$ em Pesquisa e Desenvolvimento;

- $0,4 \%$ ao Fundo Nacional de Desenvolvimento Científico e Tecnológico (FNDTC); e

- 0,2\% para o Ministério de Minas e Energia (MME). 


\subsection{CÂMARA DE COMERCIALIZAÇÃO DE ENERGIA ELÉTRICA}

Assim como o Operador Nacional do Sistema (ONS) foi criado para operar e regular o setor de geração e transmissão de energia do Sistema Interligado Nacional no Brasil, a Câmara de Comercialização de Energia Elétrica (CCEE), antigo Mercado Atacadista de Energia (MAE), tem por finalidade viabilizar a comercialização de energia elétrica no Sistema Interligado Nacional nos Ambientes de Contratação Regulada e Contratação Livre, além de efetuar a contabilização e a liquidação financeira das operações realizadas no mercado de curto prazo, as quais são auditadas externamente, nos termos da Resolução Normativa ANEEL no 109, de 26 de outubro de 2004 (Convenção de Comercialização de Energia Elétrica). As Regras e os Procedimentos de Comercialização que regulam as atividades realizadas na CCEE são aprovados pela ANEEL.

O Mercado Atacadista de Energia (MAE) foi criado conforme 0 art. 10 da Lei № 9.648, de 27/05/1998, e Decreto oㅡ 2.655, de 02/07/1998, e instituído pela assinatura de um contrato de adesão multilateral de todos os Agentes (Acordo de Mercado), como um mercado auto-regulado, com a finalidade de viabilizar as transações de energia elétrica por meio de Contratos Bilaterais e do Mercado de Curto Prazo (Mercado "Spot"), entre as empresas que executam os serviços de energia elétrica no SIN - Sistema Interligado Nacional.

A partir de 2004, após a implantação do Novo Modelo do Setor Elétrico, foi criada, em substituição ao MAE, a Câmara de Comercialização de Energia Elétrica (CCEE), autorizada através da lei ㄲo 10.848 , e regulamentada pelo Decreto ํo 5.177, de 12 de agosto de 2004.

A CCEE é uma empresa privada e sem fins lucrativos, composta de agentes de Geração, Distribuição, Comercialização e Consumidores Livres de Energia Elétrica, estes obrigados a registrarem mensalmente todos os seus 
consumos e contratos bilaterais, sujeitos a todas as regras criadas pela CCEE e homologadas pela ANEEL.

Algumas das principais responsabilidades da CCEE são:

$\checkmark$ implantação e divulgação das Regras de Comercialização e dos Procedimentos de Comercialização;

$\checkmark$ administração do Ambiente de Contratação Regulada (ACR) e Ambiente de Contratação Livre (ACL);

$\checkmark$ manutenção do registro dos dados de energia gerada e consumida pelos Agentes da CCEE;

$\checkmark$ apuração das infrações e cálculo de penalidades por variações de contratação de energia;

$\checkmark$ apuração do Preço de Liquidação das Diferenças (PLD), utilizado para liquidação da energia comercializada no curto prazo;

$\checkmark$ registro dos contratos firmados entre os Agentes da CCEE;

$\checkmark$ realização de Leilões de Energia Elétrica;

$\checkmark$ contabilização e liquidação das transações realizadas no mercado de curto prazo;

$\checkmark$ monitoramento das condutas e ações empreendidas pelos Agentes da CCEE.

A contabilização da CCEE leva em consideração toda a energia contratada por parte dos Agentes, e toda a energia efetivamente verificada (consumida ou gerada).

Para registros das informações de energia de seus Agentes (medições, contratos, etc.), a CCEE utiliza um sistema, denominado Sinercom, com as seguintes características: 
$\checkmark$ o Sinercom é um sistema computacional, baseado nas Regras de Comercialização, que possibilita o envio e recebimento das informações envolvidas na Contabilização;

$\checkmark$ uma vez inseridos os dados de medição e contratos pelos próprios Agentes, o sistema processa as informações fornecendo os resultados da Contabilização e Pré-fatura, além de gerar os relatórios com os resultados de cada Agente;

$\checkmark$ o Sinercom recebe os resultados dos Preços de Liquidação das Diferenças; $\checkmark$ seu acesso é através do site da CCEE.

\subsubsection{PLD - Preço de Liquidação das Diferenças}

O Preço de Liquidação das Diferenças (PLD) é um valor utilizado como base para valorar os volumes de energia comercializados no Mercado de Curto Prazo, calculado através de sistemas computacionais.

O Preço do PLD, expresso em $\mathrm{R} \$ / M W h$, é divulgado semanalmente (exante) e subdividido por patamar de carga, isto é, leve (horários de baixo consumo), médio (horários de médio consumo) e pesado (horários de maior consumo do sistema); e por submercado, isto é, Sudeste/Centro-Oeste (SE/CO), Sul (S), Norte (N) e Nordeste (NE).

Para a formação do preço da energia é considerado o valor do Custo Marginal de Operação - CMO, efetuado pelo ONS, que leva em consideração a máxima utilização de energia hidrelétrica disponível em cada patamar de carga e submercado, as vazões afluentes, as cargas do sistema e as restrições de transmissão interna, e entre submercados.

O CMO é limitado por um preço máximo e um preço mínimo, vigentes para o Período de Apuração, e para cada submercado, determinados pela ANEEL. 
No cálculo do PLD, efetuado pelo CCEE, são utilizadas as premissas adotadas pelo ONS, excetuando as considerações referentes às restrições de transmissão interna a cada submercado, e a energia de teste das unidades geradoras, para que a energia comercializada seja tratada como igualmente disponível em todos os pontos de consumo.

Não são consideradas para a formação de preço as usinas que apresentam inflexibilidades, isto é, restrição de geração mínima que deve ser considerada no despacho do ONS, como, por exemplo, usinas termelétricas a gás natural que possuem contrato de fornecimento do tipo take-or-pay, porém, caso a necessidade de despacho seja acima do nível de inflexibilidade, esta será considerada na formação do preço.

Os modelos computacionais utilizados para o cálculo do CMO e do PLD são o NEWAVE e o DECOMP.

O NEWAVE é um modelo que considera o planejamento para os próximos cinco anos subseqüentes da data de utilização do mesmo, com referência de preço mensal. Seu principal objetivo é determinar a estratégia de gerações hidráulica e térmica, com base no histórico de afluências, para que permita uma segurança de fornecimento futuro, informando o melhor despacho atual, apresentando as funções de custo futuro.

O DECOMP tem como objetivo apresentar o despacho das usinas hidráulicas e térmicas, minimizando o custo da primeira semana, para isso, utiliza um horizonte de doze meses, representando o primeiro mês em base semanal e considerando as afluências históricas de forma aleatória, utilizando usinas hidrelétricas e termelétricas do submercado de forma individualizada, apresentando o preço da maior usina despachada.

A diferença de custo entre o despacho sem restrição e o despacho real é coberta pelo Encargo de Serviço do Sistema - ESS.

Quando o Submercado estiver em racionamento ou for acionada a Curva de Aversão ao Risco, o cálculo do PLD contemplará o Custo do Risco. 
A curva de aversão ao risco representa a evolução ao longo do período dos requisitos mínimos de armazenamento de energia de cada submercado, necessários ao atendimento pleno da carga.

O PLD é limitado por um preço máximo e um mínimo, atualmente $\mathrm{R} \$ 569,59 / \mathrm{MWh}$ e $\mathrm{R} \$ 15,47 / \mathrm{MWh}$, respectivamente.

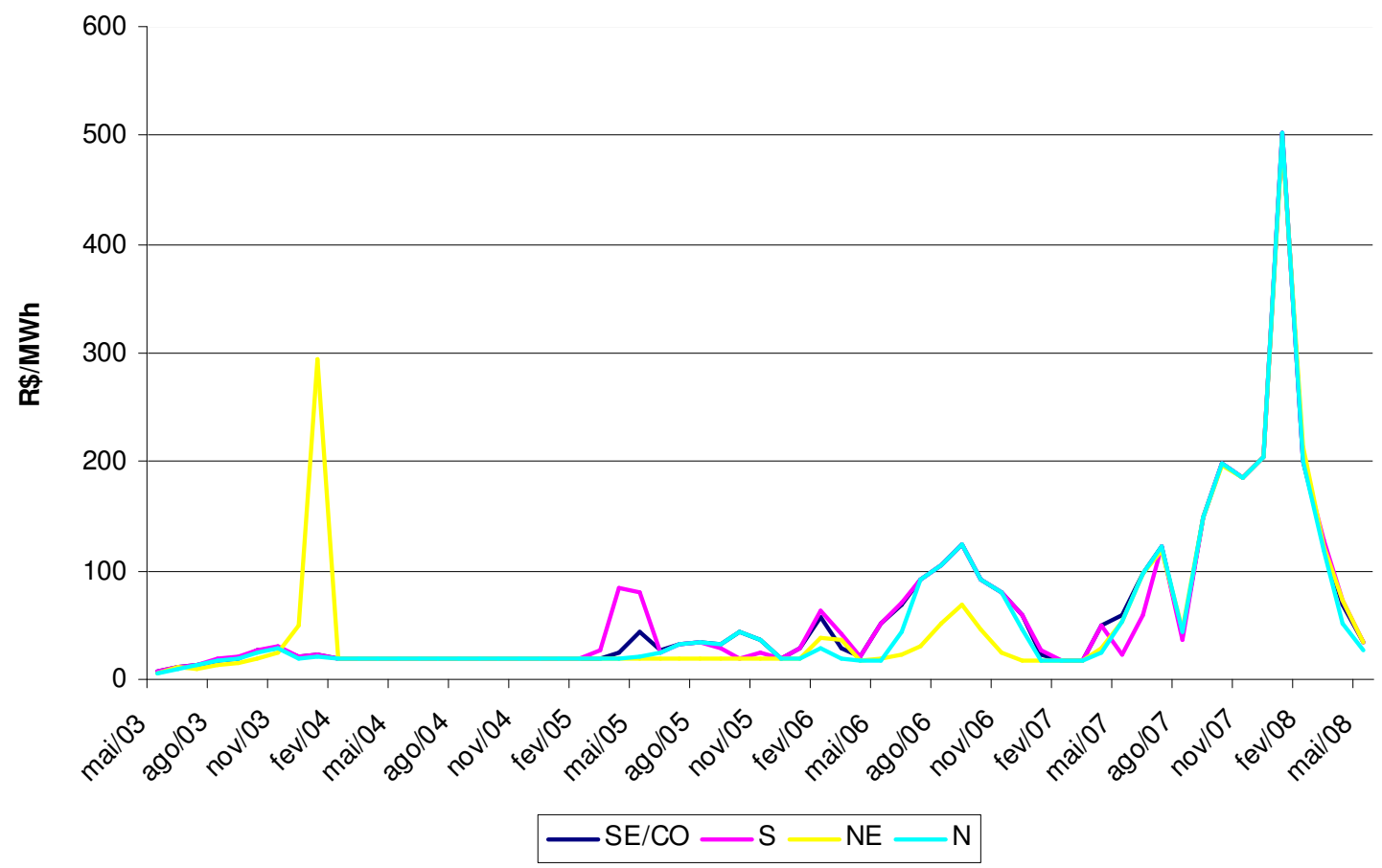

Gráfico 16 - Histórico do PLD médio (CCEE, 2008)

\subsubsection{Perdas Sistêmicas}

A transmissão de energia elétrica possui perdas elétricas de energia, o prejuízo dessas perdas é rateado entre todos os agentes da CCEE.

Todos os pontos de medição de geração e consumo são representados na CCEE, sendo que a estrutura destes pontos é definida através da Modelagem do Sistema Elétrico. 
Na CCEE, para tratar destas perdas resultantes da transmissão de energia, são projetadas a um Centro de Gravidade (CG) virtual de cada submercado todo o consumo e toda a geração de energia, desconsiderando a diferença entre a geração e consumo medidos, isto é, diminuindo o valor gerado pelos geradores e aumentando o valor consumido pelos consumidores e distribuidores, garantindo que seja possível a comparação entre as medições realizadas em diferentes pontos reais do SIN.

São mensurados, semanalmente, os valores das perdas de energia por submercado e por patamar de carga.

O rateio das perdas é o mecanismo utilizado para liquidar a geração e o consumo de energia em um ponto virtual, também dividido entre os quatro submercados.

Os agentes que participam do rateio de perdas da Rede Básica são definidos pela ANEEL.

\subsubsection{Contratos}

O acordo comercial entre os agentes de geração, comercialização, consumidores livres e autoprodutores é feito por meio de contratos de compra e venda de energia.

Todos os contratos devem ser registrados na CCEE, através do SINERCOM, independentemente do tempo de duração, visando considerar o processo de Liquidação Financeira de cada agente.

As diferenças positivas ou negativas entre os contratos são liquidadas ao valor do PLD, esses são verificados hora a hora, e suas diferenças valoradas de acordo com o período de carga correspondente ao déficit ou sobra.

Os diferentes tipos e principais contratos são: 
$\checkmark$ Contratos Bilaterais;

$\checkmark$ Contratos de Comercialização de Energia no Ambiente Regulado (CCEAR);

$\checkmark$ Contratos de Itaipu; e

$\checkmark$ Contratos de PROINFA.

Os primeiros contratos criados na CCEE e extintos a partir de janeiro de 2006 foram os Contratos Iniciais, que foram criados como instrumento para a transição entre o modelo centralizado e o competitivo, isto é, mercado livre, determinando, por Resoluções da ANEEL, montantes de energia e potências asseguradas, bem como tarifas de fornecimento às concessionárias de distribuição de energia, sendo estes contratos firmados entre diferentes agentes de Geração e Distribuição.

Os CCEAR são resultantes dos leilões de energia entre cada agente vendedor e todas as concessionárias de distribuição de energia, proporcionalmente ao seu consumo declarado. Como os Contratos Iniciais, os CCEAR foram necessários para a implementação das diretrizes do novo setor elétrico, são realizados no Ambiente de Contratação Regulada (ACR) e se apresentam como uma das possibilidades das concessionárias de atenderem seus respectivos mercados de consumidores cativos.

Os Contratos de Itaipu foram criados para registrar na CCEE a energia comercializada pela usina de Itaipu Binacional para os agentes detentores da quota parte da usina.

Os Contratos do PROINFA são aqueles criados para registrar na CCEE as quotas de energia dos distribuidores e consumidores livres referentes às energias geradas pelas usinas participantes do PROINFA.

Para o estudo deste trabalho, faz-se necessário a utilização de contratos bilaterais, como forma de indicação dos volumes de autoprodução da usina conectada ao SIN, bem como a necessidade destes para a usina ligada diretamente à carga, para possíveis negociações de sobras e déficits. 


\subsubsection{Contratos Bilaterais}

O Contrato Bilateral foi o mecanismo criado para registrar uma transação de compra e venda de energia entre agentes da CCEE, podendo ser de Gerador para Consumidor Livre, Gerador para Comercializadores, Gerador para Gerador, Comercializadores para Gerador e Comercializadores para Consumidores Livres.

Os contratos bilaterais são de livre negociação entre os agentes, variando as bases de preço, prazo de duração, montantes e submercado de entrega da energia.

Os contratos são registrados no SCL, por meio do Sinercom, pelo agente vendedor, e validados pelo agente comprador, se estiverem de acordo com as negociações previamente realizadas, visando ser considerados na contabilização da liquidação financeira.

Existem dois tipos de contratos bilaterais, os de curto prazo, com duração máxima de seis meses, e o de longo prazo, com duração superior a seis meses, tendo este último a necessidade de registro na ANEEL.

Os agentes podem sazonalizar e modular seus contratos. A Sazonalização é o processo pelo qual o valor de energia dos Contratos é distribuído em valores mensais, de acordo com a previsão do perfil de carga do Agente comprador.

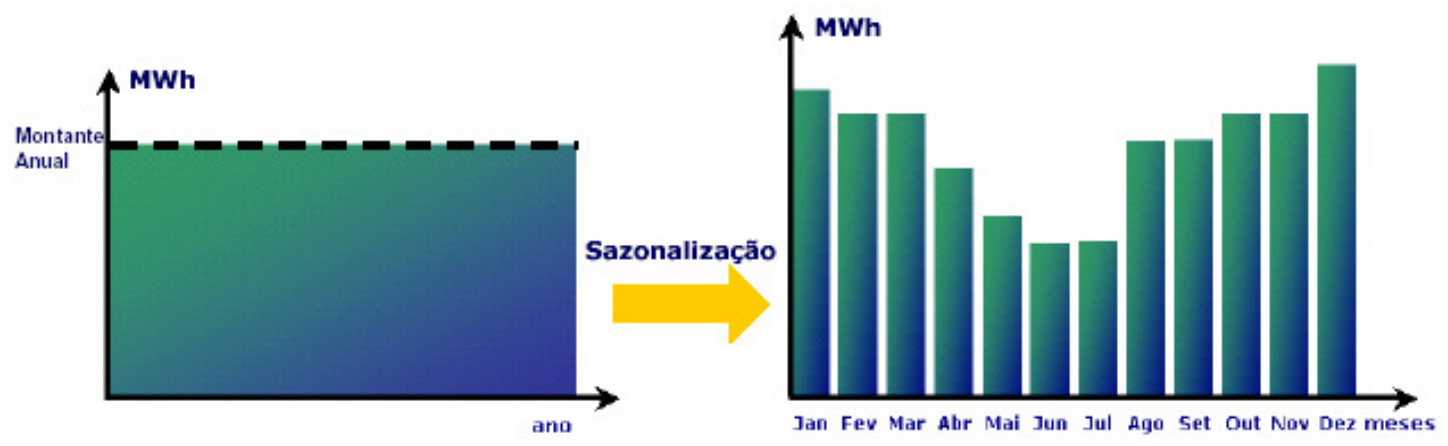

Gráfico 17 - Sazonilização de um Contrato (CCEE, 2008) 
A Modulação é o processo pelo qual os valores mensais de energia dos Contratos são distribuídos em valores horários.

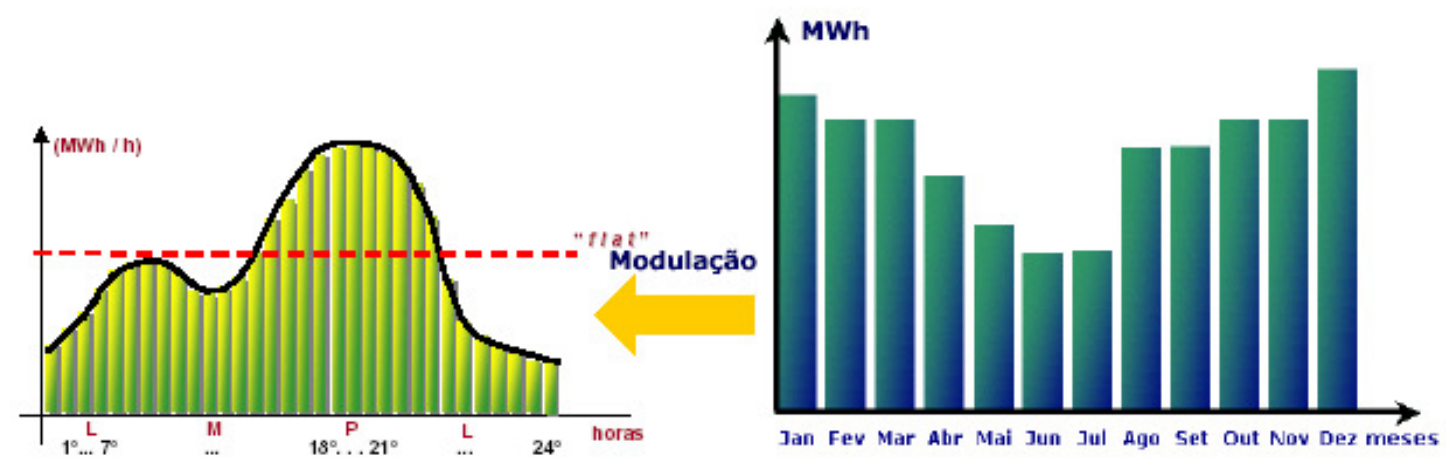

Gráfico 18 - Modulação de um Contrato (CCEE, 2008)

Caso os contratos não sejam sazonalizados ou modulados, eles serão considerados pela CCEE como FLAT, isto é, será dividido o montante total pela quantidade de meses do contrato, até doze meses, no caso da sazonalização e pela quantidade de horas do mês, no caso da modulação.

\subsubsection{Energia Assegurada}

A energia assegurada de uma usina hidrelétrica é a quantidade de energia disponível para o agente, ou agentes consorciados, proprietário da concessão da mesma, compreendendo a fração de energia que ela pode alocar no sistema elétrico, utilizando uma operação cooperativa dentro do SIN, maximizando a eficiência dos recursos energéticos do país.

Esta energia é calculada na função de valorar a máxima geração, que pode ser obtida de uma usina hidrelétrica numa série hidrológica pouco favorável, partindo de uma base histórica que, atualmente, é de aproximadamente 70 anos de vazões numa determinada bacia hidrográfica, onde se localiza a usina a ser calculada. 
Com o uso de recursos estatísticos é possível simular todas as seqüências de vazões de cada bacia hidrográfica, quantificando, assim, a máxima geração que pode ser mantida por todas as usinas ao longo dos anos, obtendo o máximo aproveitamento das usinas hidrelétricas, possibilitando, assim, maximizar o atendimento à demanda.

Os cálculos da energia assegurada das usinas hidrelétricas são de responsabilidade do Ministério de Minas e Energia (MME), sendo que a execução dos cálculos é de responsabilidade da Empresa de Pesquisa Energética (EPE). As metodologias foram estabelecidas na Portaria no 303 do MME.

Nos cálculos da energia assegurada são desconsideradas as paradas referentes às manutenções programadas e as paradas de emergência.

O ONS, por meio dos Procedimentos de Rede, é quem fiscaliza e quem delimita as paradas programadas e emergenciais por meio dos cálculos da Taxa Equivalente de Indisponibilidade Forçada (TEIF) e da Taxa Equivalente de Indisponibilidade Programada (TEIP), taxas essas que, se descumpridas, podem diminuir o valor da energia assegurada da usina.

Visando compartilhar os riscos hidrológicos das usinas hidrelétricas, tendo em vista que a operação de despacho destas é de forma centralizada, foi criado o Mecanismo de Realocação de Energia (MRE).

\subsubsection{Sazonalização e Modulação da Energia Assegurada}

A sazonalização da energia assegurada de uma usina hidrelétrica é a discretização em valores mensais do total da energia assegurada anual, determinada no Contrato de Concessão de cada usina, delimitando um máximo mensal, sendo a multiplicação da potência assegurada pela quantidade de horas do mês. 
O Gráfico 19, a seguir, mostra dois tipos de sazonalização da energia assegurada, uma sazonalização do tipo "flat", que é a divisão em valores médios da energia assegurada por todos os meses de um ano, e uma curva sazonalizada, considerando uma usina com potência assegurada de 100MW e uma energia assegurada de 50MW médios.

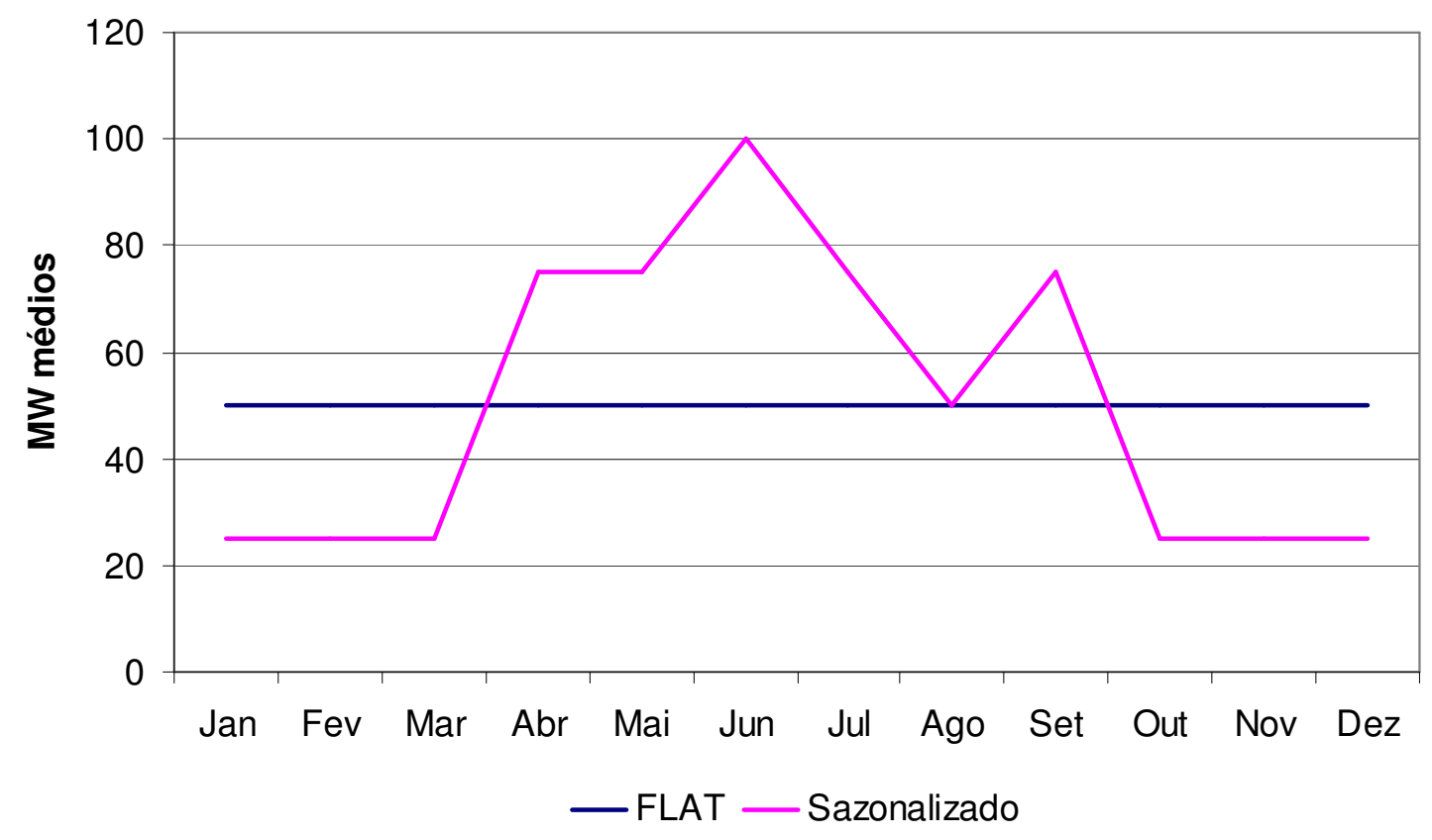

Gráfico 19 - Modulação da Energia Assegurada de uma Usina

A sazonalização de uma usina com energia assegurada e pertencente ao Mecanismo de Realocação de Energia (MRE) não é necessariamente igual à sua geração física.

A metodologia para a Sazonalização da Energia Assegurada é descrita pela CCEE em seu Procedimento de Comercialização (PdC C0.02) SAZONALIZAÇÃO DE CONTRATO INICIAL E ENERGIA ASSEGURADA, de 27 de novembro de 2006, aprovado pelo Despacho ANEEL n‥ 2773, da mesma data.

Todos os volumes mensais da sazonalização devem ser encaminhados à CCEE através da Planilha de Sazonalização de Energia Assegurada, conforme 
demonstrado na Tabela 18, com datas a serem definidas pela CCEE, geralmente no mês de dezembro, anterior ao ano da sazonalização.

ccee

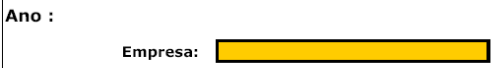

Energia Assegurada (MWh)

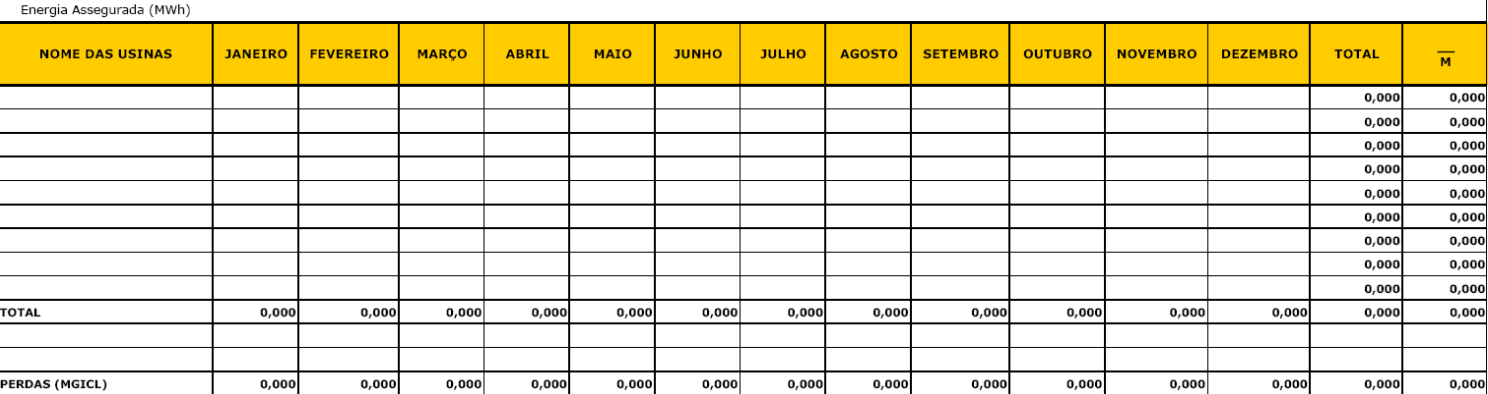

Tabela 18 - Planilha de Sazonilização de Energia Assegurada (CCEE, 2008)

O proprietário da usina, como, por exemplo, um Produtor Independente, poderá comercializar somente o montante total de energia da sazonalização encaminhada ao CCEE, referente a cada mês.

Os proprietários de concessão de Usina Hidrelétrica do tipo Autoprodução, somente poderão comercializar sua energia se 0 montante da energia sazonalizada for maior que o total do consumo de sua unidade, isto é, toda a energia de direito que exceder seu consumo.

A modulação mensal da energia assegurada é o processo de discretização horária do volume total de energia sazonalizado para o mês anterior ao mês da modulação.

A modulação é necessária para o preenchimento do consumo total registrado pela carga.

Como é feito com a energia assegurada, a modulação horária pode ter o valor máximo da potência assegurada da usina hidrelétrica referente. 


\subsubsection{Mecanismo de Realocação de Energia}

Buscando otimizar o uso dos recursos hidrelétricos do SIN foi criado o Mecanismo de Realocação de Energia (MRE), que é um equacionamento financeiro que visa o compartilhamento dos riscos hidrológicos que afetam todos os Agentes de Geração, sem os prejudicar comercialmente, garantindo a entrega da energia assegurada.

Nas regras do setor elétrico brasileiro, o ONS é o responsável pela otimização dos recursos. Devido à geração de energia ser hidrotémica, com grande predominância de usinas hidrelétricas, que são vulneráveis às condições hidrológicas, cabe ao ONS a decisão de utilizar a água ou economizá-la, prospectando uma hidrologia desfavorável.

O MRE proporciona a segurança aos agentes detentores de usinas hidrelétricas para que comercializem sua energia assegurada, independentemente da geração física da usina, considerando que o grupo de usinas participantes do MRE teve a geração suficiente para a realocação de energia.

Todas as usinas que possuem despacho centralizado, isto é, usinas despachadas para geração pelo ONS, são obrigatoriamente participantes do MRE, ficando opcionalmente às Pequenas Centrais Hidrelétricas a participação nesse mecanismo.

Dentre as usinas despachadas pelo ONS estão as com potência assegurada superior a $50 \mathrm{MW}$, sendo que as usinas com potência entre $30 \mathrm{e}$ 50MW estão habilitadas a participar do MRE desde que mostrem influenciar na qualidade de operação do SIN, através de estudos específicos.

É facultativa a participação de usinas não despachadas pelo ONS, sendo possível, através de solicitação formalizada de participação no MRE junto à ANEEL, contendo neste pedido as séries hidrológicas e vazões médias de, no mínimo 30 anos, valores de indisponibilidade forçada e programada, rendimento 
do conjunto turbina-gerador, queda bruta média e perdas hidráulicas. Faz-se também necessária esta usina ser um Agente cadastrado na CCEE.

O MRE nasceu da necessidade de separar os interesses comerciais da maior eficiência no uso do parque hidrológico brasileiro, retirando a influência de mercado dos despachos físicos das usinas.

A realocação de energia funciona da seguinte forma, exemplificada através do gráfico 20. Considerando uma geração física tipo "flat", e uma energia assegurada sazonalizada durante o ano, com potência assegurada de 100MW e energia assegurada de 50MW médios, temos que, quando a sazonalização é inferior à geração medida, a usina cede (+) energia ao MRE, complementando a energia de outras usinas que tiveram sua geração inferior à sua sazonalização, e quando a geração é inferior à sazonalização da usina, esta estaria recebendo (-) energia de outras usinas que tiveram sua geração superior à sua sazonalização no período.

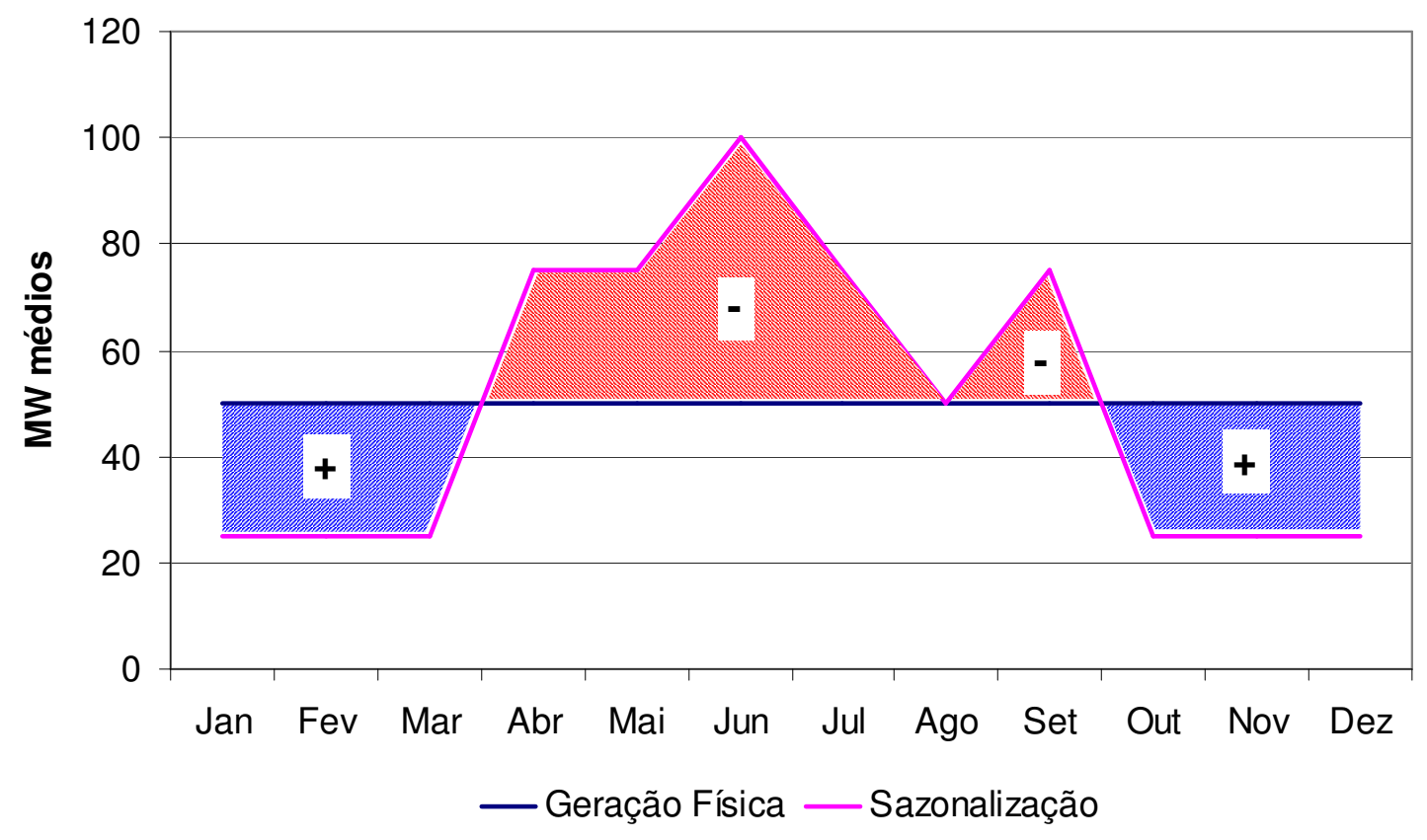

Gráfico 20 - Exemplificação do MRE 
A tarifa de remuneração para as usinas que geraram energia acima de sua energia assegurada, bem como o pagamento pelas que geraram abaixo, é a Tarifa de Energia de Otimização - TEO, criada pelo Decreto 2.655, de 2 de julho de 1998.

Para o ano de 2009, a TEO está definida em $\mathrm{R} \$ 8,18$ / MWh, conforme publicado na Resolução Homologatória $n^{-0}$ 755, de 16 de dezembro de 2008, através de seu Artigo 1ํ․

A contabilização da energia transferida entre as usinas participantes do MRE fica a cargo da CCEE.

Nos casos de geração superior ou igual à sazonalização da energia assegurada pela totalidade das usinas consideradas no MRE, cedidas ao sistema ou "pool" de geração, é chamada de energia secundária, sendo esta calculada para cada semana e período de apuração.

A energia excedente superior à energia sazonalizada, isto é, a energia secundária, é distribuída proporcionalmente à contribuição de energia assegurada de cada Agente de geração, sendo esta precificada de acordo com o PLD do período apurado.

A alocação da energia excedente do MRE é prioritariamente exercida entre os Agentes de geração de um mesmo submercado, sendo somente o excedente do gerado no mesmo submercado transferido a outros submercados.

Os excedentes alocados a outros submercados ficam nos riscos de variação dos preços de cada um destes, podendo ser minimizados pela alocação do Excedente Financeiro.

No caso da geração total dos agentes participantes serem inferiores ao total da Energia Assegurada, modulada no sistema, não existirá a energia secundária, e será adotado um fator de ajuste para multiplicar pela energia assegurada da Usina, o que resultará na energia assegurada ajustada. 
Nesse caso, verifica-se que as usinas participantes do MRE não conseguiram preencher seu valor de energia assegurada, com isso, necessitam comprar a diferença no mercado SPOT.

\subsubsection{Encargos de Serviços do Sistema}

Os Encargos de Serviços do Sistema (ESS) constituem num encargo que quantifica os custos incorridos na deficiência ou restrição de operação de agentes de geração, que não foram incluídos nos cálculos do PLD. Também é incluído nesse valor os custos da prestação de Serviços Ancilares. Esse encargo é expresso em $\mathrm{R} \$ / M W h$, e é pago por todos os agentes cadastrados na CCEE, na proporção de seu consumo.

O ESS tem a função de garantir a confiabilidade e estabilidade do sistema, visando o atendimento da demanda de cada submercado.

As restrições de operação na visão do ONS são restrições operativas internas aos Submercados, e são consideradas para que o despacho atenda o mercado e assegure a estabilidade do sistema.

No cálculo do PLD a CCEE retira as restrições de transmissão internas de cada submercado, porém, nos despachos do ONS, essas restrições são consideradas, desta forma, existe a possibilidade de um diferente despacho referente ao considerado para o cálculo do PLD pela CCEE. Esta diferença, não contemplada pela CCEE, é paga pelas usinas através do Encargo de Serviço de Sistema.

Podemos ver, no seguinte exemplo, a diferença entre o considerado com despacho pelo CCEE e o real despacho realizado pelo ONS.

$\checkmark$ Alterações na configuração do sistema decorrentes da queda de uma linha de transmissão, uma grande chuva que vier a acontecer após o cálculo do 
modelo de otimização, e que podem alterar radicalmente o planejamento de operação de Curto Prazo do ONS, em relação ao panorama desenhado pelo modelo de otimização.

Têm direito ao Pagamento dos custos de operação os interconectores internacionais e as usinas térmicas não-emergenciais.

As restrições de operação podem ser:

$\checkmark$ Do tipo "Local" quando seu impacto se limitar ao despacho de geração de seu próprio Submercado;

$\checkmark$ Do tipo "Subsistema", quando esta interferir no despacho de geração de outro Submercado.

O ONS deverá informar à CCEE a lista das usinas atingidas pela restrição de operação e o tipo de restrição, que pode ser Local ou Subsistema.

No ano de 2008, foi criado o ESS - Segurança Energética, que tem como objetivo estabelecer uma quantidade mínima, em percentual, de armazenamento de água nos reservatórios das usinas hidrelétricas. Com a criação deste, foi incluído mais um encargo para os consumidores de energia, que é um rateio mensal do custo do despacho fora de ordem de mérito das termelétricas entre todos os consumidores.

\subsection{Serviços Ancilares}

Os Serviços Ancilares foram criados visando a garantia da qualidade e segurança da energia gerada, contribuindo para a confiabilidade do Sistema Interligado Nacional. 
Os critérios de remuneração dos Serviços Ancilares são definidos pela ANEEL e somente têm o direito a este serviço as usinas que possuem:

$\checkmark$ Reserva de Prontidão - o custo de consumo de combustível durante o período em que a usina estiver em reserva de prontidão será ressarcido via ESS, após confirmação do mesmo pela ANEEL;

$\checkmark$ Compensação Síncrona - o Gerador receberá o equivalente à Energia Reativa gerada ou consumida, valorizada a Tarifa de Serviços Ancilares (R\$3,64/MVArh, em 2007 - Resolução Homologatória n 412, de 19 de dezembro de 2006);

$\checkmark$ Ressarcimento para Prestação de Serviços Ancilares - usinas atualmente em operação que venham a ter o provimento de SA determinado pela ANEEL, ou que tiveram autorização para reposição dos equipamentos e peças destinadas à prestação de SA, terão o custo de implantação ou reposição auditado e aprovado pela mesma, e ressarcido via ESS;

$\checkmark$ Ressarcimento pelo Custo de Operação e Manutenção dos Equipamentos de Supervisão e Controle e de Comunicação Necessários à Participação da Usina no CAG - Controle Automático de Geração - montante Financeiro pelo qual a Usina deverá ser ressarcida referente aos custos incorridos pela operação e manutenção dos equipamentos de supervisão e controle, e de comunicação necessários à participação da usina no CAG;

$\checkmark$ Ressarcimento pelo Custo de Implantação, Operação e Manutenção de Sistema Especial de Proteção - montante Financeiro pelo qual a Usina deverá ser ressarcida referente aos custos incorridos pela implantação, operação e manutenção de SEP; 
$\checkmark$ Ressarcimento pelo Custo de Operação e Manutenção dos Equipamentos de Auto-restabelecimento - montante Financeiro pelo qual a Usina deverá ser ressarcida referente aos custos incorridos pela operação e manutenção dos equipamentos de Auto-restabelecimento.

A Consolidação dos Encargos de Serviços de Sistema consiste em determinar o total de Encargos a serem pagos aos Perfis de Geração dos Agentes no mês de apuração.

Este montante é formado pelo total de Encargos por Restrição de Operação e pelo total de Encargos de Serviços Ancilares, que somados, formam o montante total de Encargos de Serviços do Sistema.

Serão utilizados para o abatimento dos Encargos de Serviços do Sistema os seguintes recursos:

$\checkmark$ penalidade de Medição;

$\checkmark$ penalidade por Falta de Combustível;

$\checkmark$ excedente Financeiro Remanescente do Mês;

$\checkmark$ saldo do Excedente Financeiro do mês anterior;

$\checkmark$ multa pelo Não-Aporte de Garantia Financeira.

\subsubsection{Liquidação Financeira}

Consiste na contabilização dos pagamentos ou recebimentos dos resultados do sistema de contabilização, levando em consideração as exposições positivas ou negativas de energia, semanalmente e patamarizado.

E um processo multilateral: transações são realizadas entre o sistema e o conjunto de agentes, não sendo possível a identificação de contrapartes.

Para a operacionalização do processo de liquidação, todos os agentes da CCEE devem manter uma conta bancária, conforme determinação da mesma, para efetuar os créditos ou débitos do resultado da liquidação.

No caso de crédito, são desconsiderados, proporcionalmente, os valores não pagos pelos agentes, isto é, existe um rateio da inadimplência. 


\section{METODOLOGIA EMPREGADA}

Com o intuito de verificar a viabilidade econômica e financeira da autoprodução direta, isto é, ligada diretamente na unidade de consumo, comparada com esta mesma usina ligada no Sistema Interligado Nacional (SIN), despachada, centralizadamente pelo ONS, utilizando as regras de mercado e sazonalização da energia assegurada, foi elaborada uma planilha de cálculos utilizando a metodologia a ser apresentada.

Primeiramente, como base de cálculo, deve-se utilizar as seguintes premissas, na visão do consumidor:

$\checkmark$ uma indústria de Alumínio, com carga de 39,96MW;

$\checkmark$ consumo "flat", isto é, sem sazonalidade, devido a este tipo de indústria ser do tipo eletrointensiva;

$\checkmark$ conexão na Rede Básica, com TUST no valor de $\mathrm{R} \$ 5,792 \mathrm{~kW}$, valor retirado pela média dos encargos atribuídos ao consumidor CBA, de acordo com a Resolução Homologatória $n^{0}$ 671, de 24 de junho de 2008;

$\checkmark$ modalidade de Autoprodutor, isento dos pagamentos de CCC, CDE e PROINFA sobre a parcela autoproduzida.

A seguir, as premissas utilizadas para a UHE Pirajú, considerando os dados de geração física cedidos pela CBA, e de acordo com o Contrato de Concessão no 303/1998:

$\checkmark$ energia assegurada de 42,47MW médios ou 372.037MWh/ano;

$\checkmark$ potência assegurada de 65MW; 
$\checkmark$ conexão na Rede Básica, com TUST Geração no valor de $R \$ 1,549 \mathrm{~kW}$, de acordo com a Resolução Homologatória $n^{\circ}$ 671, de 24 de junho de 2008;

$\checkmark$ geração Física cedida pela CBA conforme Gráfico 21:

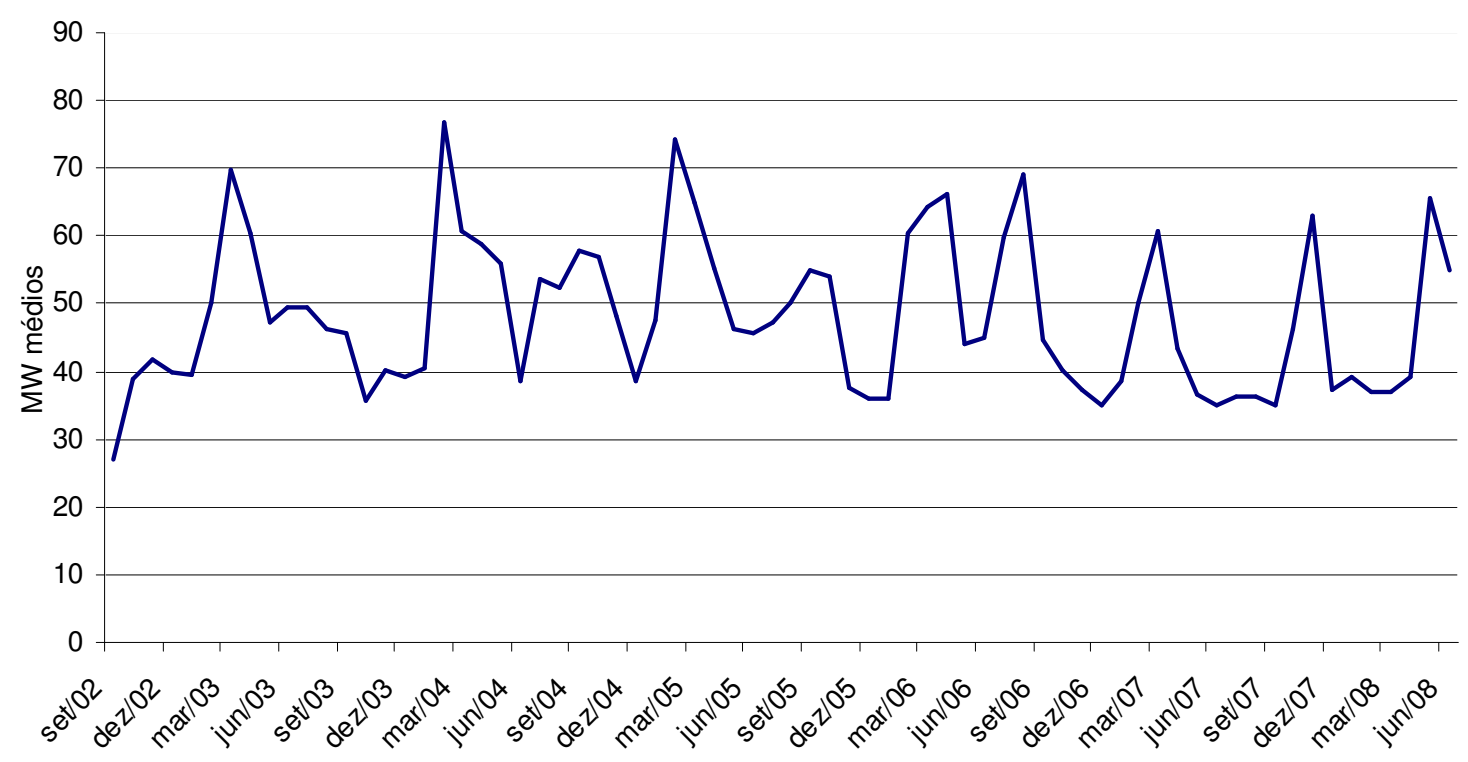

Gráfico 21 - Geração Física da UHE Pirajú.

Para o estudo em questão, serão utilizados alguns cenários, baseados na geração física e PLD dos anos de 2006 e 2007.

Os cenários a serem estudados serão os seguintes:

1) usina conectada diretamente à carga. Este cenário será a base de comparação com os outros 3 cenários.

2) usina conectada na Rede Básica, com sazonalização de sua energia assegurada de forma "flat", considerando esta a forma mais conservadora de sazonalização para um autoprodutor, cuja finalidade é manter seu custo de energia constante. 
3) usina conectada na Rede Básica, com sazonalização de sua energia assegurada de forma "agressiva", contando que a sazonalização que é "ex-ante" acertou todos os meses de PLD's mais altos dos anos de 2006 e 2007.

4) usina conectada na Rede Básica, com sazonalização de sua energia assegurada de forma "moderada", contando que, na sazonalização, foi considerada uma energia mínima mensal, no valor da metade da energia assegurada da usina e uma energia máxima de 55MW médios, isto é, $10 \mathrm{MW}$ médios abaixo da potência assegurada da usina, sendo esse valor utilizado nos maiores PLD's dos anos de 2006 e 2007.

As usinas dos cenários 1 e 2 serão remuneradas na mesma proporção da energia assegurada, considerando a energia na barra da usina, isto é, antes da aplicação de perdas.

Nos cenários 3 e 4 , as usinas serão remuneradas na proporção da sazonalização da energia assegurada, tembém na barra da usina.

A remuneração da usina considerada, no valor de $R \$ 99,00 / \mathrm{MWh}$, é referente à transferência de energia produzida da UHE Pirajú à unidade consumidora, este valor foi retirado da venda de energia derivada da UHE Baixo Iguaçu, realizado no $7^{\circ}$ Leilão de Energia Nova da CCEE (Edital $n^{\circ}$ 003/2008ANEEL).

A seguir, será demonstrada a metodologia e a premissa utilizadas para todos os cenários considerados. 


\section{Cenário 1: Usina ligada diretamente à carga:}

- Energia: conforme mencionado, o custo da energia será a multiplicação da energia do mês pelo valor de $\mathrm{R} \$ 99,00 / \mathrm{MWh}$, nesse caso, como a remuneração da usina não se altera com a geração física, consideramos a mesma energia da sazonalização flat (Cenário 2), conforme a seguir;

$$
E=E A^{*} H m^{*} C E
$$

Onde:

E: $\quad$ custo da energia em Reais;

EA: energia Assegurada;

Hm: quantidade de horas no mês;

CE: custo da energia (R\$99,00/MWh).

- Demanda de Reserva: para a fórmula escrita no Art. 50ำ da Resolução Normativa $n^{-0} 304 / 08$, temos as seguintes premissas, considerando que a usina fique totalmente desligada por 6 (seis) dias no ano, por indisponibilidades devido a saídas forçadas:

$$
E_{R C}=\left(M_{P} * T_{P}+M_{f p} * T_{f p}\right) * \frac{n_{u}}{n_{m}}
$$

Onde:

$\mathrm{E}_{\mathrm{RC}}$ : encargo mensal pelo uso da reserva de capacidade, em $\mathrm{R} \$$;

$\mathrm{n}_{\mathrm{u}}$ : 6 (seis) dias por ano ou 0,5 (meio) dia por mês;

$\mathrm{n}_{\mathrm{m}}$ : número de dias do mês em referência; 
$\mathrm{T}_{\mathrm{p}}$ : utilizada a Tarifa de Uso do Sistema de Transmissão (TUST) = $\mathrm{R} \$ 5,79 / \mathrm{kW}$;

$T_{\mathrm{fp}}$ : não utilizado devido ao valor ser inexistente na Rede Básica;

$\mathrm{M}_{\mathrm{p}}$ : utilizado o valor de $39.960 \mathrm{~kW}$ devido este ser o valor total da demanda de energia da Fábrica;

$M_{\mathrm{tp}}$ : Não utilizado devido ao fato de não ser cobrada tarifa para este segmento horário na Rede Básica.

- CCC, CDE e PROINFA: a cobrança destes encargos é paga pelo consumidor na proporção da parcela de energia adquirida do sistema, excluindo a parte de autoprodução.

- TUST Carga: a cobrança é feita pelo uso do sistema de transmissão, referente à carga, para tal foi utilizada a seguinte expressão:

$$
T U S T_{C}=\left[C-\left(G E R_{M I N} * F S\right)\right]^{*} T
$$

Onde:

TUSTC: valor expresso em Reais do total mensal da cobrança do acesso à Rede Básica da Carga;

C: $\quad$ Carga da Fábrica $=39,96 \mathrm{MW}$;

GER $_{\text {MIN }}$ : menor geração do período estudado, no caso, Set/07, no valor de 34,92MW;

FS: $\quad$ Fator de Segurança de $90 \%$;

T: $\quad$ Valor da Tarifa de Uso do Sistema de Transmissão; 
- TUST Geração:

a cobrança é feita pelo uso do sistema de transmissão, referente à geração. No caso em questão, a sobra de energia vendida ao sistema, para isso, foi utilizada a seguinte expressão:

$$
T U S T_{G}=\left(G E R_{M A X}-C\right) * F S * T_{G}
$$

Onde:

TUST $_{\mathrm{G}}$ : valor expresso em Reais do total mensal da cobrança do acesso a Rede Básica da Geração;

C: $\quad$ Carga da Fábrica $=39,96 \mathrm{MW}$;

GER $_{\text {MAX: }}$ maior geração do período estudado, no caso, Ago/06, no valor de 69,09MW;

FS: $\quad$ Fator de Segurança de $90 \%$;

$\mathrm{T}_{\mathrm{G}}$ : $\quad$ valor da Tarifa de Uso do Sistema de Transmissão da Geração, no caso, é utilizada a Tarifa da UHE Piraju, no valor de $\mathrm{R} \$ 1,549 \mathrm{~kW}$, de acordo com a Resolução Homologatória $n^{\circ} 671$, de 24 de junho de 2008;

- $P \& D$ :

a cobrança deste encargo é feita pela parcela de energia comercializada, isto é, vendida ao mercado, e é aplicado o valor de $1 \%$ sobre a receita obtida, calculado conforme fórmula a seguir:

$P \& D=\left(E_{G E R}-E_{C}\right) * P_{R B} * P L D * 1 \%$

P\&D: $\quad$ valor expresso em Reais do encargo quando da venda de energia;

$\mathrm{E}_{\mathrm{GER}}: \quad$ Energia Gerada no mês; 
$E_{C}: \quad$ Energia Consumida no mês;

$\mathrm{P}_{\mathrm{RB}}$ : Perdas da Rede Básica, para levar o valor ao Centro de Gravidade do Submercado, considerando perdas de 3\%;

PLD: Valor do PLD do mês da venda de energia.

- ESS: Encargo cobrado sobre a parcela de energia adquirida no SIN, neste estudo foi utilizada a tarifa de $\mathrm{R} \$ 0,5 / \mathrm{MWh}$, calculada conforme fórmula a seguir:

$$
E S S=\left(E_{C}-E_{G E R}\right) * 0,5
$$

ESS: valor expresso em Reais, encargo cobrado quando da compra de energia do sistema;

$\mathrm{E}_{\mathrm{GER}}$ : Energia Gerada no mês;

$\mathrm{E}_{\mathrm{C}}$ : Energia Consumida no mês;

- Comercialização de Energia: pagamento ou recebimento referente à compra ou venda, respectivamente, de energia no mercado SPOT, calculado conforme fórmula a seguir:

$$
C E=\left(E_{C}-E_{G E R}\right) * P_{R B} * P L D
$$

CE: receita ou encargo referente à venda ou compra de energia no mercado SPOT;

$\mathrm{E}_{\mathrm{GER}}$ : Energia Gerada no mês;

$E_{C}$ : Energia Consumida no mês; 

$\mathrm{P}_{\mathrm{RB}}$ : $\quad$ Perdas da Rede Básica, para levar o valor ao Centro de Gravidade do Submercado, considerando perdas de 3\%. Em caso de compra, adiciona-se $3 \%$, em caso de venda, retira-se $3 \%$;
PLD: $\quad$ valor do PLD do mês da venda ou compra da energia.

\section{Cenário 2: Usina ligada à Rede Básica com Sazonalização da Energia assegurada "Flat":}

- Energia: conforme mencionado, o custo da energia será a multiplicação da energia do mês pelo valor de $\mathrm{R} \$ 99,00 / \mathrm{MWh}$, conforme abaixo;

$$
E=E A^{*} H m^{*} C E
$$

Onde:

E: $\quad$ custo da energia em Reais;

EA: Energia Assegurada;

Hm: quantidade de horas no mês;

CE: Custo da energia (R\$99,00/MWh).

- CCC, CDE e PROINFA: neste caso não existira cobrança destes encargos, pois a energia sazonalizada flat e o consumo são iguais.

- TUST Carga:

a cobrança é feita pelo uso do sistema de transmissão, referente à carga, para isso, foi utilizada a seguinte expressão: 


$$
T U S T_{C}=C^{*} T
$$

Onde:

TUSTC: $_{\text {C }}$ valor expresso em Reais do total mensal da cobrança do acesso à Rede Básica da Carga;

C: $\quad$ Carga da Fábrica $=39,96 \mathrm{MW}$;

T: $\quad$ valor da Tarifa de Uso do Sistema de Transmissão.

- TUST Geração: $\quad$ A cobrança é feita pelo uso do sistema de transmissão referente à geração, utilizada a seguinte expressão:

$$
T U S T_{G}=P A * T_{G}
$$

Onde:

TUST $_{\mathrm{G}}$ : valor expresso em Reais do total mensal da cobrança do acesso à Rede Básica da Geração;

PA: $\quad$ Potência Assegurada da Usina;

$\mathrm{T}_{\mathrm{G}}$ : $\quad$ valor da Tarifa de Uso do Sistema de Transmissão da Geração, no caso, é utilizada a Tarifa da UHE Piraju, no valor de $R \$ 1,549 \mathrm{~kW}$, de acordo com a Resolução Homologatória $n^{\circ} 671$, de 24 de junho de 2008.

- Comercialização de Energia: neste caso não existiram compra ou venda de energia, pois a energia sazonalizada flat e o consumo são iguais.

- ESS: encargo cobrado sobre a parcela de energia adquirida no SIN, neste estudo foi utilizada a tarifa de $\mathrm{R} \$ 0,5 / \mathrm{MWh}$, calculada conforme fórmula a seguir:

$$
E S S=E_{C} * 0,5
$$


ESS: valor expresso em Reais, encargo cobrado quando da compra de energia do sistema;

$\mathrm{E}_{\mathrm{C}}$ : $\quad$ Energia Consumida no mês.

- MRE:

pagamento ou remuneração referente à energia transacionada entre os agentes de geração participantes do MRE, valorada pela TEO, sendo utilizada a seguinte expressão:

$$
M R E=\left(E_{G E R}-E_{S A Z}\right) * T E O
$$

Onde:

MRE: $\quad$ valor expresso em Reais, podendo ser um débito ou um crédito, variando conforme energia gerada no determinado mês;

$E_{G E R}: \quad$ Energia Gerada no mês;

ESAZ: Energia Sazonalizada para o mês;

TEO: Tarifa de Energia de Otimização - TEO, no valor de $\mathrm{R} \$ 8,18 / \mathrm{MWh}$. 


\section{Cenários 3 e 4: Usina ligada à Rede Básica com Sazonalização da Energia} assegurada agressiva ou conservadora:

- Energia: conforme mencionado, o custo da energia será a multiplicação da energia do mês pelo valor de $\mathrm{R} \$ 99,00 / \mathrm{MWh}$, conforme "a fórmula" abaixo:

$$
E=E A^{*} H m^{*} C E
$$

Onde:

E: $\quad$ Custo da energia em Reais;

EA: Energia Assegurada do mês;

Hm: quantidade de horas no mês;

CE: Custo da energia (R\$99,00/MWh).

- CCC, CDE e PROINFA: a cobrança destes encargos é paga pelo consumidor na proporção da parcela de energia adquirida do sistema, excluindo a parte de autoprodução.

- TUST Carga:

a cobrança é feita pelo uso do sistema de transmissão, referente à carga, para isso, foi utilizada a seguinte expressão:

$$
T U S T_{C}=C^{*} T
$$

Onde:

TUST : valor expresso em Reais do total mensal da cobrança do acesso à Rede Básica da Carga;

C: $\quad$ Carga da Fábrica $=39,96 \mathrm{MW}$; 
T: $\quad$ valor da Tarifa de Uso do Sistema de Transmissão.

- TUST Geração: a cobrança é feita pelo uso do sistema de transmissão referente à geração, utilizada a seguinte expressão:

$$
T U S T_{G}=P A^{*} T_{G}
$$

Onde:

TUST $T_{G}$ : valor expresso em Reais do total mensal da cobrança do acesso a Rede Básica da Geração;

PA: $\quad$ Potência Assegurada da Usina;

$T_{G}$ : valor da Tarifa de Uso do Sistema de Transmissão da Geração, no caso, é utilizada a Tarifa da UHE Piraju, no valor de $\mathrm{R} \$ 1,549 \mathrm{~kW}$, de acordo com a Resolução Homologatória $n^{\circ} 671$, de 24 de junho de 2008.

- Comercialização de Energia: pagamento ou recebimento referente à compra ou venda, respectivamente, de energia no mercado SPOT, calculada conforme fórmula a seguir:

$$
C E=\left(E_{C}-E_{S A Z}\right) * P_{R B} * P L D
$$

CE: receita ou encargo referente à venda ou compra de energia no mercado SPOT;

$\mathrm{E}_{\mathrm{SAZ}}$ : Energia Sazonalizada no mês;

$\mathrm{E}_{\mathrm{C}}$ : $\quad$ Energia Consumida no mês; 
$\mathrm{P}_{\mathrm{RB}}$ : $\quad$ Perdas da Rede Básica, sendo para a $\mathrm{E}_{\mathrm{SAZ}}$, retira-se $3 \%$, e para $E_{C}$ inclui-se 3\% na multiplicação de $\mathrm{P}_{\mathrm{RB}}$;

PLD: $\quad$ valor do PLD do mês da venda ou compra da energia.

- ESS:

encargo cobrado sobre a parcela de energia adquirida no SIN, neste estudo foi utilizada a tarifa de $\mathrm{R} \$ 0,5 / \mathrm{MWh}$, calculada conforme fórmula a seguir:

$$
E S S=E_{C} * 0,5
$$

ESS: valor expresso em Reais, encargo cobrado quando da compra de energia do sistema;

$E_{C}$ : $\quad$ Energia Consumida no mês.

- MRE:

pagamento ou remuneração referente à energia transacionada entre os agentes de geração participantes do MRE, valorada pela TEO, sendo utilizada a seguinte expressão:

$$
M R E=\left(E_{G E R}-E_{S A Z}\right) * T E O
$$

Onde:

MRE: $\quad$ valor expresso em Reais, podendo ser um débito ou um crédito, variando conforme energia gerada no determinado mês;

E $E_{\text {GER }}$ Energia Gerada no mês;

ESAZ: Energia Sazonalizada para o mês;

TEO: Tarifa de Energia de Otimização - TEO, no valor de $\mathrm{R} \$ 8,18 / \mathrm{MWh}$. 


\section{RESULTADOS OBTIDOS}

Para a obtenção dos resultados foram consideradas as metodologias de cálculo utilizadas no CAPÍTULO 5 anterior, os dados de energia e tarifas apresentadas nesta dissertação, e conforme quantidade de energia gerada pela UHE Piraju nos anos de 2006 e 2007, comparadas com a energia assegurada "Flat" desta mesma usina, e o PLD médio realizado nestes anos e apresentados no Gráfico 22, a seguir.

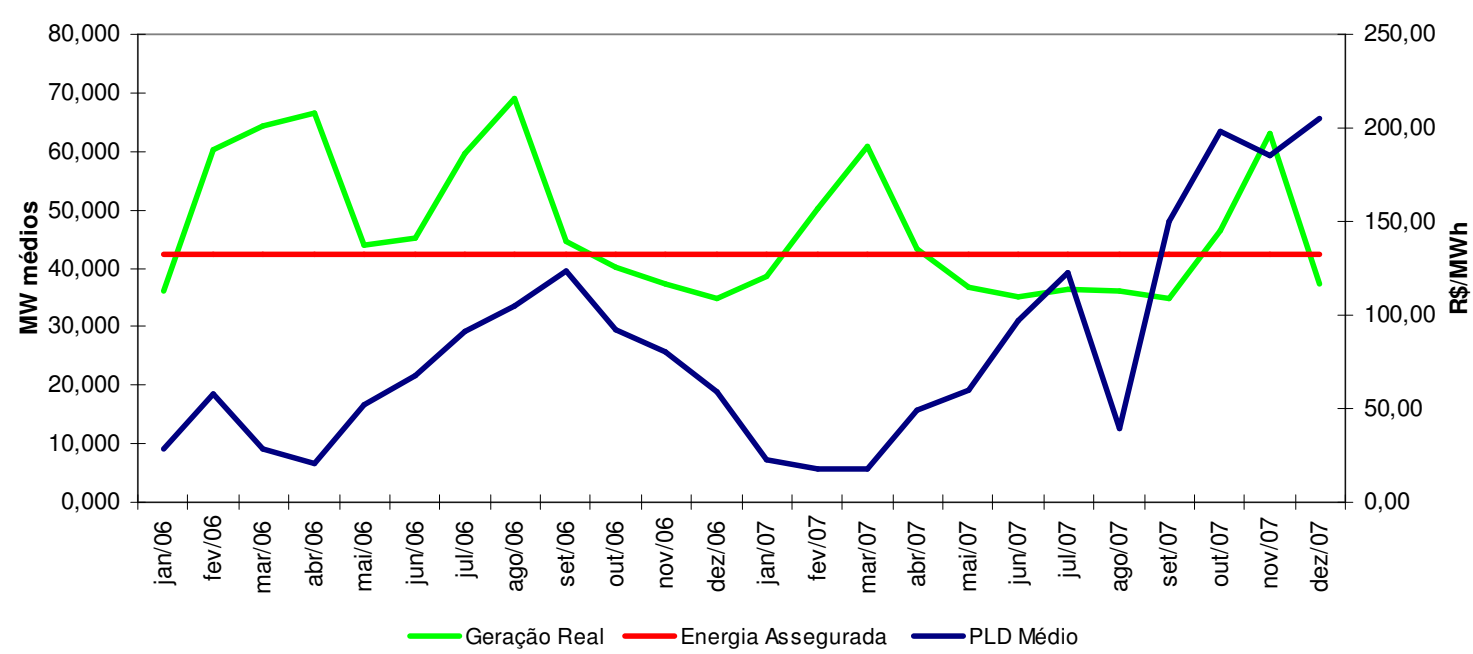

Gráfico 22 - Comparativo entre Geração, Energia Assegurada Flat e PLD médio

No Gráfico 23 são apresentadas as curvas de energia utilizadas na base de cálculo dos diversos cenários apresentados, sazonalizadas, ou no caso do Cenário 1, a geração física real. 


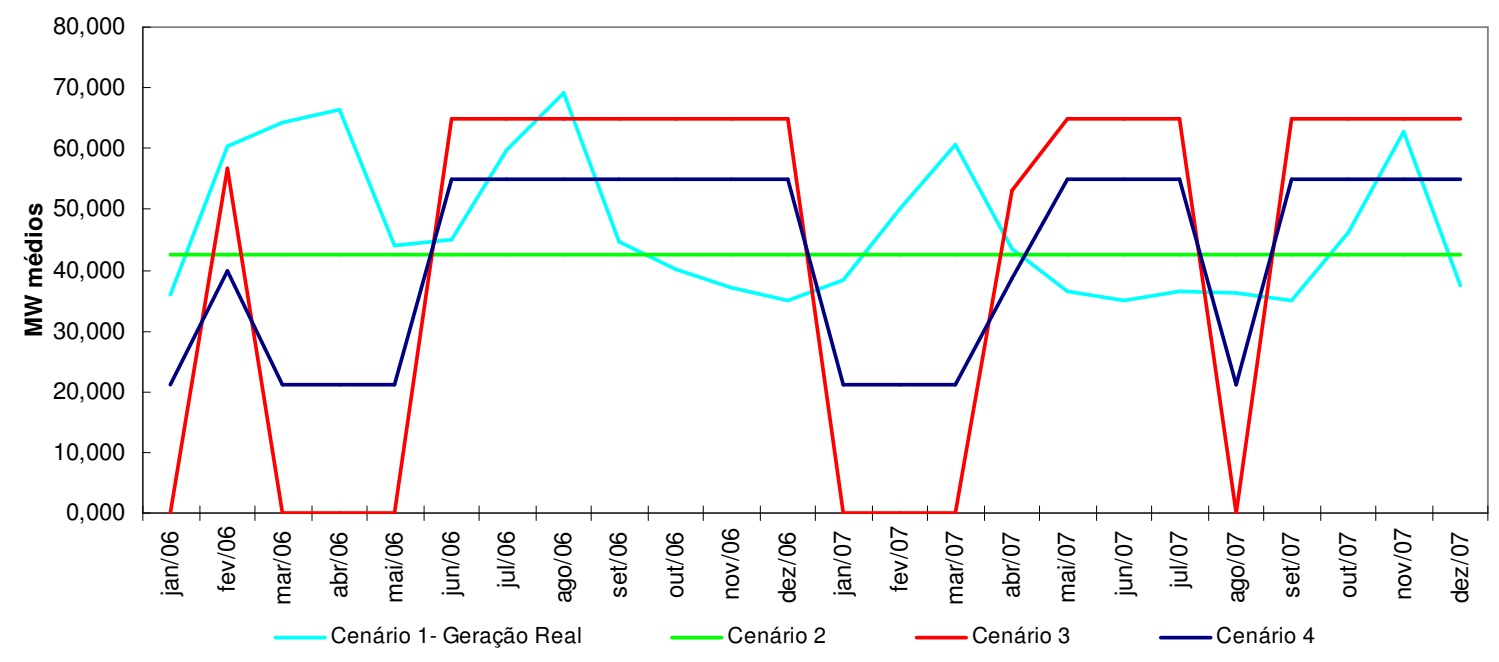

Gráfico 23 - Energia média dos cenários estudados

Nas tabelas 20, 21, 22, 23, 24, 25, 26 e 27, são demonstrados os resultados em Reais das fórmulas e dados utilizados para os diversos cenários, para cada mês estudado e na tabela 19 a seguir um resumo comparativo do que foi considerado em cada cenário.

\begin{tabular}{|c|c|c|c|c|}
\hline & Cenário 1 & Cenário 2 & Cenário 3 & Cenário 4 \\
\hline Energia & Custo fixo & Custo fixo & Energia alocada $(\mathrm{x})$ Custo & Energia alocada $(\mathrm{x})$ Custo \\
\hline Demanda de Reserva & Aplicável & Não se aplica & Não se aplica & Não se aplica \\
\hline CCC/CDE/PROINFA & Energia adquirida $(x)$ encargo & Não se aplica & Energia adquirida $(\mathrm{x}$ ) encargo & Energia adquirida $(x)$ encargo \\
\hline TUST - Carga & \begin{tabular}{|c|} 
Diferença entre a carga e a \\
menor geração do período \\
estudado $(x)$ TUST considerada
\end{tabular} & $\begin{array}{c}\text { Carga Fábrica }(x) \text { TUST } \\
\text { considerada }\end{array}$ & $\begin{array}{l}\text { Carga Fábrica }(\mathrm{x}) \text { TUST } \\
\text { considerada }\end{array}$ & $\begin{array}{l}\text { Carga Fábrica }(x) \text { TUST } \\
\text { considerada }\end{array}$ \\
\hline TUST - Geração & $\begin{array}{c}\text { Diferença entre a maior geração } \\
\text { do período estudado e a carga } \\
\text { (x) TUST considerada }\end{array}$ & $\begin{array}{c}\text { Potência assegurada }(x) \text { TUST } \\
\text { da UHE Pirajú }\end{array}$ & $\begin{array}{c}\text { Potência assegurada }(x) \text { TUST } \\
\text { da UHE Pirajú }\end{array}$ & $\begin{array}{c}\text { Potência assegurada (x) TUST } \\
\text { da UHE Pirajú }\end{array}$ \\
\hline $\begin{array}{l}\text { Comercialização de } \\
\text { Energia }\end{array}$ & $\begin{array}{c}\text { Falta ou sobra de energia }(x) \text { a } \\
\text { diferença entre consumo e } \\
\text { energia (x) PLD (excluído perdas } \\
\text { da Rede Básica) }\end{array}$ & Não se aplica & $\begin{array}{c}\text { Falta ou sobra de energia }(x) \text { a } \\
\text { diferença entre consumo e } \\
\text { energia (x) PLD (excluído perdas } \\
\text { da Rede Básica) }\end{array}$ & $\begin{array}{c}\text { Falta ou sobra de energia }(x) \text { a } \\
\text { diferença entre consumo e } \\
\text { energia (x) PLD (excluído perdas } \\
\text { da Rede Básica) } \\
\end{array}$ \\
\hline ESS & $\begin{array}{l}\text { Compra de Energia }(\mathrm{x}) \text { tarifa } \\
\text { adotada }\end{array}$ & Não se aplica & $\begin{array}{c}\text { Compra de Energia }(\mathrm{x}) \text { tarifa } \\
\text { adotada }\end{array}$ & $\begin{array}{c}\text { Compra de Energia }(\mathrm{x}) \text { tarifa } \\
\text { adotada }\end{array}$ \\
\hline MRE & Não se aplica & $\begin{array}{l}\text { Diferença entre geração física e } \\
\text { energia sazonalizada }(x) \text { TEO }\end{array}$ & $\begin{array}{c}\text { Diferença entre geração física e } \\
\text { energia sazonalizada }(x) \text { TEO }\end{array}$ & $\begin{array}{l}\text { Diferença entre geração física e } \\
\text { energia sazonalizada }(x) \text { TEO }\end{array}$ \\
\hline P\&D & \begin{tabular}{|c|}
$\begin{array}{c}\text { Energia vendida }(\mathrm{x}) \text { PLD }(\mathrm{x}) 1 \% \\
\text { (excluído perdas da Rede } \\
\text { Básica) }\end{array}$ \\
\end{tabular} & Não se aplica & \begin{tabular}{|c|}
$\begin{array}{c}\text { Energia vendida }(\mathrm{x}) \text { PLD }(\mathrm{x}) 1 \% \\
\text { (excluído perdas da Rede } \\
\text { Básica) }\end{array}$ \\
\end{tabular} & $\begin{array}{c}\text { Energia vendida }(\mathrm{x}) \text { PLD }(\mathrm{x}) 1 \% \\
\text { (excluído perdas da Rede } \\
\text { Básica) }\end{array}$ \\
\hline
\end{tabular}

Tabela 19 - Resumo comparativo entre os Cenários 


\section{Cenário 1 - Autoprodutor Direto}

Ano 2006

em $R \$$

\begin{tabular}{|c|c|c|c|c|c|c|c|c|c|c|c|c|}
\hline Mês & Janeiro & Fevereiro & Março & Abril & Maio & Junho & Julho & Agosto & Setembro & Outubro & Novembro & Dezembro \\
\hline Energia & $.128 .168,64$ & $2.825 .442,64$ & $3.128 .168,64$ & \begin{tabular}{|l|}
$3.027 .259,97$ \\
\end{tabular} & $3.128 .168,64$ & $3.027 .259,97$ & $3.128 .168,64$ & $3.128 .168,64$ & $3.027 .259,97$ & $3.128 .168,64$ & 3.027.259,97 & $3.128 .168,64$ \\
\hline Demanda de Reserva & $3.733,04$ & $4.133,01$ & $3.733,04$ & $3.857,47$ & $3.733,04$ & $3.857,47$ & $3.733,04$ & $3.733,04$ & $3.857,47$ & $3.733,04$ & $3.857,47$ & $3.733,04$ \\
\hline CCC/CDE/PROINFA & $63.874,11$ & 0,00 & 0,00 & 0,00 & 0,00 & 0,00 & 0,00 & 0,00 & 0,00 & 0,00 & $3.539,70$ & $82.593,00$ \\
\hline TUST - Carga & $.417,34$ & $49.417,34$ & $.417,34$ & $49.417,34$ & $9.417,34$ & $49.417,34$ & $49.417,34$ & $49.417,34$ & $49.417,34$ & $99.417,34$ & $9.417,34$ & $49.417,3$ \\
\hline TUST - Geração & $49.634,61$ & $49.634,61$ & $9.634,61$ & $9.634,61$ & $49.634,61$ & $49.634,61$ & $49.634,61$ & $49.634,61$ & $49.634,61$ & $49.634,61$ & $49.634,61$ & $49.634,6$ \\
\hline P\&D & 0,00 & $7.715,23$ & 987,91 & $.847,96$ & $.539,71$ & $2.399,17$ & $12.949,58$ & $22.069,46$ & $4.092,29$ & 126,73 & 0,00 & 0,00 \\
\hline ESS & $1.490,49$ & 0,00 & 0,00 & 0,00 & 0,00 & 0,00 & 0,00 & 0,00 & 0,00 & 0,00 & $1.015,99$ & $1.927,29$ \\
\hline Comerci & $.375,40$ & $1.523,04)$ & $(498.790,58)$ & $(384.796,05)$ & $3.970,50)$ & $(239.916,74)$ & $(1.294 .958,05)$ & $(2.206 .946,08)$ & $(409.229,16)$ & $(12.672,56)$ & $164.224,95$ & $226.457,14$ \\
\hline TOTAL & $.381 .693,64$ & $2.164 .819,79$ & $2.737 .150,96$ & \begin{tabular}{|l|}
$2.749 .221,30$ \\
\end{tabular} & $3.078 .522,83$ & $2.892 .651,82$ & $1.948 .945,15$ & $1.046 .077,01$ & $2.725 .032,53$ & $3.218 .407,80$ & $3.338 .950,03$ & $3.541 .931,06$ \\
\hline
\end{tabular}

Tabela 20 - Autoprodutor ligado Direto à Fábrica - 2006

Ano 2007

em $R \$$

\begin{tabular}{|c|c|c|c|c|c|c|c|c|c|c|c|c|}
\hline Mês & Janeiro & Fevereiro & Março & Abril & Maio & Junho & Julho & Agosto & Setembro & Outubro & Novembro & Dezembro \\
\hline Energia & $3.128 .168,64$ & $2.825 .442,64$ & $3.128 .168,64$ & $3.027 .259,97$ & $3.128 .168,64$ & $3.027 .259,97$ & $3.128 .168,64$ & $3.128 .168,64$ & $3.027 .259,97$ & $3.128 .168,64$ & $3.027 .259,97$ & $3.128 .168,64$ \\
\hline Demanda de Reserva & $3.733,04$ & $4.133,01$ & $3.733,04$ & $3.857,47$ & $3.733,04$ & $3.857,47$ & $3.733,04$ & $3.733,04$ & $3.857,47$ & $3.733,04$ & $3.857,47$ & $3.733,04$ \\
\hline CCC/CDE/PROINFA & $24.301,72$ & 0,00 & 0,00 & 0,00 & $54.514,67$ & $76.909,54$ & $58.455,48$ & $61.903,70$ & $80.087,62$ & 0,00 & 0,00 & $42.856,41$ \\
\hline TUST - Carga & $49.417,34$ & $49.417,34$ & $49.417,34$ & $49.417,34$ & $49.417,34$ & $49.417,34$ & $49.417,34$ & $49.417,34$ & $49.417,34$ & $49.417,34$ & $49.417,34$ & $49.417,34$ \\
\hline TUST - Geração & $49.634,61$ & $49.634,61$ & $49.634,61$ & $49.634,61$ & $49.634,61$ & $49.634,61$ & $49.634,61$ & $49.634,61$ & $49.634,61$ & $49.634,61$ & $49.634,61$ & $49.634,61$ \\
\hline P\&D & 0,00 & $1.159,20$ & $2.642,96$ & $1.199,66$ & 0,00 & 0,00 & 0,00 & 0,00 & 0,00 & $9.093,94$ & $29.695,81$ & 0,00 \\
\hline ESS & 567,08 & 0,00 & 0,00 & 0,00 & $1.272,09$ & $1.794,67$ & $1.364,05$ & $1.444,51$ & $1.868,83$ & 0,00 & 0,00 & $1.000,05$ \\
\hline Comercialização de Energia & $25.654,55$ & $(115.919,90)$ & $(264.296,39)$ & $(119.966,12)$ & $152.549,18$ & $348.704,77$ & $334.437,68$ & $113.452,07$ & $558.892,90$ & $(909.393,88)$ & $(2.969 .580,53)$ & $409.879,51$ \\
\hline TOTAL & 3.281.476,98 & $|2.813 .866,90|$ & $2.969 .300,20$ & $3.011 .402,93$ & 3.439.289,56 & $3.557 .578,37$ & $3.625 .210,84$ & $3.407 .753,91$ & $3.771 .018,74$ & $2.330 .653,69$ & $190.284,67$ & $3.684 .689,59$ \\
\hline
\end{tabular}

Tabela 21 - Autoprodutor ligado Direto à Fábrica - 2007 
Cenário 2 - Autoprodutor ligado à Rede Básica com Sazonalização da Energia assegurada "Flat":

Ano 2006

em $R \$$

\begin{tabular}{|c|c|c|c|c|c|c|c|c|c|c|c|c|}
\hline Mês & Janeiro & Fevereiro & Março & Abril & Maio & Junho & Julho & Agosto & Setembro & Outubro & Novembro & \begin{tabular}{|l|} 
Dezembro \\
\end{tabular} \\
\hline Energia & $.128 .168,64$ & $2.825 .442,64$ & $3.128 .168,64$ & \begin{tabular}{|l|}
$3.027 .259,97$ \\
\end{tabular} & $3.128 .168,64$ & $3.027 .259,97$ & $3.128 .168,64$ & $3.128 .168,64$ & $3.027 .259,97$ & $3.128 .168,64$ & $3.027 .259,97$ & $3.128 .168,64$ \\
\hline CCC/CDE/PROI & 0,00 & 0,00 & 0,00 & 0,00 & 0,00 & 0,00 & 0,00 & 0,00 & 0,00 & 0,00 & 0,00 & 0,00 \\
\hline TUST - Carga & $231.448,32$ & $231.448,32$ & $231.448,32$ & $231.448,32$ & $231.448,32$ & $231.448,32$ & $231.448,32$ & $231.448,32$ & $231.448,32$ & $231.448,32$ & $31.448,32$ & $31.448,32$ \\
\hline TUST - Geração & $100.685,00$ & $0.685,00$ & $0.685,00$ & $100.685,00$ & $0.685,00$ & $100.685,00$ & $100.685,00$ & $100.685,00$ & $.685,00$ & $.685,00$ & 685,00 & 685,00 \\
\hline Comercialização & 0,00 & 0,00 & 0,00 & 0,00 & 0,00 & 0,00 & 0,00 & 0,00 & 0,00 & 0,00 & 0,00 & 0,00 \\
\hline ESS & $15.324,87$ & $13.841,81$ & $15.324,87$ & $14.830,52$ & $15.324,87$ & $14.830,52$ & $15.324,87$ & $15.324,87$ & $14.830,52$ & $15.324,87$ & 830,52 & $15.324,87$ \\
\hline \begin{tabular}{|l} 
MRE \\
\end{tabular} & $52.351,81$ & $(146.340,39)$ & \begin{tabular}{|l|}
$(177.424,39)$ \\
\end{tabular} & $(195.420,39)$ & $(13.088,19)$ & $(20.859,19)$ & $(140.941,59)$ & $(217.751,79)$ & $(18.159,79)$ & $18.977,41$ & $42.944,81$ & $61.677,01$ \\
\hline P\&D & 0,00 & 0,00 & 0,00 & 0,00 & 0,00 & 0,00 & 0,00 & 0,00 & 0,00 & 0,00 & 0,00 & 0,00 \\
\hline TOTAL & $527.978,64$ & $3.025 .077,39$ & $3.298 .202,44$ & \begin{tabular}{|l|}
$3.178 .803,42$ \\
\end{tabular} & $3.462 .538,64$ & $3.353 .364,62$ & \begin{tabular}{|l|}
$3.334 .685,24$ \\
\end{tabular} & $3.257 .875,04$ & $3.356 .064,02$ & $3.494 .604,24$ & $3.417 .168,62$ & $3.537 .303,84$ \\
\hline
\end{tabular}

Tabela 22 - Autoprodutor ligado à Rede Básica com Sazonalização da Energia assegurada "Flat” - 2006

Ano 2007

em $R \$$

\begin{tabular}{|c|c|c|c|c|c|c|c|c|c|c|c|c|}
\hline Mês & Janeiro & Fevereiro & Março & Abril & Maio & Junho & Julho & Agosto & Setembro & Outubro & Novembro & Dezembro \\
\hline Energia & $3.128 .168,64$ & $2.825 .442,64$ & $3.128 .168,64$ & $3.027 .259,97$ & $3.128 .168,64$ & $3.027 .259,97$ & $3.128 .168,64$ & $3.128 .168,64$ & $3.027 .259,97$ & $3.128 .168,64$ & $3.027 .259,97$ & $3.128 .168,64$ \\
\hline CCC/CDE/PROINFA & 0,00 & 0,00 & 0,00 & 0,00 & 0,00 & 0,00 & 0,00 & 0,00 & 0,00 & 0,00 & 0,00 & 0,00 \\
\hline TUST - Carga & $231.448,32$ & $231.448,32$ & $231.448,32$ & $231.448,32$ & $231.448,32$ & $231.448,32$ & $231.448,32$ & $231.448,32$ & $231.448,32$ & $231.448,32$ & $231.448,32$ & $231.448,32$ \\
\hline TUST - Geração & $100.685,00$ & $100.685,00$ & $100.685,00$ & $100.685,00$ & $100.685,00$ & $100.685,00$ & $100.685,00$ & $100.685,00$ & $100.685,00$ & $100.685,00$ & $100.685,00$ & $100.685,00$ \\
\hline Comercialização de Energia & 0,00 & 0,00 & 0,00 & 0,00 & 0,00 & 0,00 & 0,00 & 0,00 & 0,00 & 0,00 & 0,00 & 0,00 \\
\hline ESS & $15.324,87$ & $13.841,81$ & $15.324,87$ & $14.830,52$ & $15.324,87$ & $14.830,52$ & $15.324,87$ & $15.324,87$ & $14.830,52$ & $15.324,87$ & $14.830,52$ & $15.324,87$ \\
\hline MRE & $32.638,01$ & $(62.168,19)$ & \begin{tabular}{|l|}
$(149.775,99)$ \\
\end{tabular} & $(7.934,79)$ & $47.689,21$ & $60.122,81$ & $49.652,41$ & $51.370,21$ & $61.758,81$ & $(31.493,19)$ & $(167.362,99)$ & $41.881,41$ \\
\hline P\&D & 0,00 & 0,00 & 0,00 & 0,00 & 0,00 & 0,00 & 0,00 & 0,00 & 0,00 & 0,00 & 0,00 & 0,00 \\
\hline TOTAL & 3.508.264,84 & $\mid 3.109 .249,59$ & 3.325.850,84 & $3.366 .289,02$ & 3.523.316,04 & $3.434 .346,62$ & $3.525 .279,24$ & $3.526 .997,04$ & $3.435 .982,62$ & $3.444 .133,64$ & $3.206 .860,82$ & $3.517 .508,24$ \\
\hline
\end{tabular}

Tabela 23 - Autoprodutor ligado à Rede Básica com Sazonalização da Energia assegurada "Flat" - 2007 
Cenário 3- Autoprodutor ligado à Rede Básica com Sazonalização da Energia assegurada "Agressiva":

Ano 2006

em $R \$$

\begin{tabular}{|c|c|c|c|c|c|c|c|c|c|c|c|c|}
\hline Mês & Janeiro & Fevereiro & Março & Abril & Maio & Junho & Julho & Agosto & Setembro & Outubro & Novembro & Dezembro \\
\hline Energia & 0,00 & $.781 .503,00$ & 0,00 & 0,00 & 0,00 & $4.633 .200,00$ & $4.787 .640,00$ & $4.787 .640,00$ & $4.633 .200,00$ & $4.787 .640,00$ & $4.633 .200,00$ & $4.787 .640,00$ \\
\hline CCC/CDE/PROINFA & $656.146,40$ & 0,00 & $656.146,40$ & $634.980,38$ & $656.146,40$ & 0,00 & 0,00 & 0,00 & 0,00 & 0,00 & 0,00 & 0,00 \\
\hline TUST - Carga & $231.448,32$ & $231.448,32$ & $231.448,32$ & $231.448,32$ & $231.448,32$ & $231.448,32$ & $231.448,32$ & $231.448,32$ & $231.448,32$ & $231.448,32$ & $: 31.448,32$ & $231.448,32$ \\
\hline TUST - Geração & $100.685,00$ & $0.685,00$ & $100.685,00$ & $100.685,00$ & $100.685,00$ & $100.685,00$ & $100.685,00$ & $100.685,00$ & $100.685,00$ & $00.685,00$ & $00.685,00$ & 100.685, \\
\hline Comercialização de $\mathrm{E}$ & $877.018,30$ & $511.379,24)$ & $874.568,52$ & $618.468,59$ & $589.595,66$ & $.005 .113,65)$ & $.390 .636,69)$ & $.606 .040,04)$ & $(1.834 .047,41)$ & $(1.413 .890,46)$ & $1.196 .542,72)$ & $(898.788,84$ \\
\hline ESS & $15.324,87$ & $.841,81$ & $15.324,87$ & $14.830,52$ & $15.324,87$ & $14.830,52$ & $15.324,87$ & $15.324,87$ & $14.830,52$ & $15.324,87$ & $14.830,52$ & $15.324,87$ \\
\hline MRE & $295.052,60)$ & $(28.787,27)$ & $24.828,80)$ & $(542.824,80)$ & $(360.492,60)$ & $163.436,40$ & $43.354,00$ & $(33.456,20)$ & $166.135,80$ & $203.273,00$ & $227.240,40$ & $245.972,60$ \\
\hline P\&D & 0,00 & 13,79 & 0,00 & 0,00 & 0,00 & 1,14 & 06,37 & 60,40 & 40,47 & 88,90 & 65,43 & $8.987,89$ \\
\hline TOTAL & $585.570,28$ & $592.425,42$ & $1.353 .344,31$ & $057.588,01$ & $2.232 .707,64$ & $4.148 .537,72$ & $3.801 .721,86$ & $3.511 .662,34$ & $3.330 .592,70$ & $3.938 .619,63$ & $4.022 .826,94$ & 491.269, \\
\hline
\end{tabular}

Tabela 24 - Autoprodutor ligado à Rede Básica com Sazonalização da Energia assegurada "Agressiva” - 2006

Ano 2007

em $\mathrm{R} \$$

\begin{tabular}{|c|c|c|c|c|c|c|c|c|c|c|c|c|}
\hline Mês & Janeiro & Fevereiro & Março & Abril & Maio & Junho & Julho & Agosto & Setembro & Outubro & Novembro & Dezembro \\
\hline Energia & 0,00 & 0,00 & 0,00 & $3.781 .503,00$ & $4.787 .640,00$ & $4.633 .200,00$ & $4.787 .640,00$ & 0,00 & $4.633 .200,00$ & $4.787 .640,00$ & $4.633 .200,00$ & $4.787 .640,00$ \\
\hline CCC/CDE/PROINFA & $656.146,40$ & $592.648,36$ & $656.146,40$ & 0,00 & 0,00 & 0,00 & 0,00 & $656.146,40$ & 0,00 & 0,00 & 0,00 & 0,00 \\
\hline TUST - Carga & $231.448,32$ & $231.448,32$ & $231.448,32$ & $231.448,32$ & $231.448,32$ & $231.448,32$ & $231.448,32$ & $231.448,32$ & $231.448,32$ & $231.448,32$ & $231.448,32$ & $231.448,32$ \\
\hline TUST - Geração & $100.685,00$ & $100.685,00$ & $100.685,00$ & $100.685,00$ & $100.685,00$ & $100.685,00$ & $100.685,00$ & $100.685,00$ & $100.685,00$ & $100.685,00$ & $100.685,00$ & $100.685,00$ \\
\hline Comercialização de Energia & $692.672,97$ & $486.516,77$ & $538.643,57$ & $(343.215,21)$ & $(917.300,07)$ & $(1.438 .308,90)$ & \begin{tabular}{|l|l|}
$(1.875 .447,22)$ \\
\end{tabular} & $1.202 .531,72$ & $(2.213 .796,49)$ & $(3.031 .098,44)$ & $(2.740 .559,55)$ & $(3.135 .128,47)$ \\
\hline ESS & $15.324,87$ & $13.841,81$ & $15.324,87$ & $14.830,52$ & $15.324,87$ & $14.830,52$ & $15.324,87$ & $15.324,87$ & $14.830,52$ & $15.324,87$ & $14.830,52$ & $15.324,87$ \\
\hline MRE & $(314.766,40)$ & $(409.572,60)$ & $(497.180,40)$ & $78.621,16$ & $231.984,80$ & $244.418,40$ & $233.948,00$ & $(296.034,20)$ & $246.054,40$ & $152.802,40$ & $16.932,60$ & $226.177,00$ \\
\hline P\&D & 0,00 & 0,00 & 0,00 & $3.432,15$ & $9.173,00$ & $14.383,09$ & $18.754,47$ & 0,00 & $22.137,96$ & $30.310,98$ & $27.405,60$ & $31.351,28$ \\
\hline TOTAL & $1.381 .511,15$ & \begin{tabular}{|l|}
$1.015 .567,67$ \\
\end{tabular} & $1.045 .067,75$ & $3.867 .304,94$ & $4.458 .955,92$ & $3.800 .656,43$ & $3.512 .353,44$ & $1.910 .102,10$ & $3.034 .559,71$ & $2.287 .113,13$ & $2.283 .942,48$ & $2.257 .498,01$ \\
\hline
\end{tabular}

Tabela 25 - Autoprodutor ligado à Rede Básica com Sazonalização da Energia assegurada “Agressiva” - 2007 


\section{Cenário 4-Autoprodutor ligado à Rede Básica com Sazonalização da Energia assegurada "Moderada":}

Ano 2006

em $R \$$

\begin{tabular}{|c|c|c|c|c|c|c|c|c|c|c|c|c|}
\hline Mês & Janeiro & Fevereiro & Março & Abril & Maio & Junho & Julho & Agosto & Setembro & Outubro & Novembro & Dezembro \\
\hline Energia & $1.564 .085,16$ & $2.660 .256,72$ & $1.564 .085,16$ & $1.513 .630,80$ & $1.564 .085,16$ & $3.920 .400,00$ & $4.051 .080,00$ & $4.051 .080,00$ & $3.920 .400,00$ & $4.051 .080,00$ & $3.920 .400,00$ & $4.051 .080,00$ \\
\hline CCC/CDE/PROINFA & $328.073,01$ & $34.648,41$ & $328.073,01$ & $317.490,01$ & $328.073,01$ & 0,00 & 0,00 & 0,00 & 0,00 & 0,00 & 0,00 & 0,00 \\
\hline TUST - Carga & $231.448,32$ & $231.448,32$ & $231.448,32$ & $231.448,32$ & $231.448,32$ & $231.448,32$ & $231.448,32$ & $231.448,32$ & $231.448,32$ & $231.448,32$ & $31.448,32$ & $231.448,32$ \\
\hline TUST - Geração & $100.685,00$ & $0.685,00$ & $00.685,00$ & $100.685,00$ & $100.685,00$ & $100.685,00$ & $100.685,00$ & $100.685,00$ & $100.685,00$ & $100.685,00$ & $100.685,00$ & 100.685, \\
\hline Comercialização de $\mathrm{E}$ & $438.508,90$ & $3.820,12$ & $437.284,01$ & $309.234,12$ & $794.797,37$ & $(558.991,79)$ & $(773.399,59)$ & $(893.195,70)$ & $(1.020 .001,51)$ & $(786.332,13)$ & $(665.454,65)$ & $(499.859,47$ \\
\hline ESS & $15.324,87$ & $13.841,81$ & $15.324,87$ & $14.830,52$ & $15.324,87$ & $.830,52$ & $15.324,87$ & $15.324,87$ & $14.830,52$ & $15.324,87$ & $14.830,52$ & $15.324,87$ \\
\hline MRE & $(121.350,30)$ & $66.650,95)$ & $51.126,50)$ & $(369.122,50)$ & $(186.790,30)$ & $81.636,40$ & $(38.446,00)$ & $115.256,20)$ & $84.335,80$ & $121.473,00$ & $145.440,40$ & $164.172,60$ \\
\hline P\&D & 0,00 & 0,00 & 0,00 & 0,00 & 0,00 & 9,92 & 4,00 & 1,96 & 0,02 & 3,32 & $6.654,55$ & $4.998,59$ \\
\hline TOTAL & $556.774,95$ & $2.968 .049,44$ & $2.325 .773,87$ & 2.118.196,26 & $2.847 .623,43$ & $3.795 .598,37$ & $3.594 .426,59$ & $3.399 .018,24$ & $3.341 .898,14$ & $3.741 .542,38$ & $3.754 .004,13$ & 4.067 .8 \\
\hline
\end{tabular}

Tabela 26 - Autoprodutor ligado à Rede Básica com Sazonalização da Energia assegurada “Moderada”- 2006

Ano 2007

em $\mathrm{R} \$$

\begin{tabular}{|c|c|c|c|c|c|c|c|c|c|c|c|c|}
\hline Mês & Janeiro & Fevereiro & Março & Abril & Maio & Junho & Julho & Agosto & Setembro & Outubro & Novembro & Dezembro \\
\hline Energia & $.564 .085,16$ & $1.412 .722,08$ & \begin{tabular}{|l|}
$1.564 .085,16$ \\
\end{tabular} & \begin{tabular}{|l|}
$2.761 .165,44$ \\
\end{tabular} & $4.051 .080,00$ & $3.920 .400,00$ & $4.051 .080,00$ & $1.564 .085,16$ & $3.920 .400,00$ & $4.051 .080,00$ & $3.920 .400,00$ & $4.051 .080,00$ \\
\hline CCC/CDE/PROINFA & $328.073,01$ & $296.324,01$ & $328.073,01$ & $55.814,41$ & 0,00 & 0,00 & 0,00 & $328.073,01$ & 0,00 & 0,00 & 0,00 & 0,0 \\
\hline TUST - Carga & $231.448,32$ & $231.448,32$ & $231.448,32$ & $231.448,32$ & 31.448,32 & $231.448,32$ & $231.448,32$ & $231.448,32$ & $231.448,32$ & $231.448,32$ & $231.448,32$ & $231.448,32$ \\
\hline TUST - Geração & $100.685,00$ & $100.685,00$ & $100.685,00$ & $100.685,00$ & $100.685,00$ & $100.685,00$ & $100.685,00$ & $100.685,00$ & $100.685,00$ & $100.685,00$ & $100.685,00$ & $100.685,00$ \\
\hline Comercialização de E & $346.336,29$ & $243.258,25$ & $269.321,63$ & $128.574,96$ & $(510.154,45)$ & $(799.912,39)$ & $(1.043 .025,92)$ & $601.265,51$ & $(1.231 .198,14)$ & $(1.685 .738,85)$ & $(1.524 .156,27)$ & $(1.743 .594,93)$ \\
\hline ESS & $15.324,87$ & $13.841,81$ & $15.324,87$ & $14.830,52$ & $15.324,87$ & $14.830,52$ & $15.324,87$ & $15.324,87$ & $14.830,52$ & $15.324,87$ & $14.830,52$ & $15.324,87$ \\
\hline MRE & $(141.064,10)$ & $(235.870,30)$ & $(323.478,10)$ & $(38.471,45)$ & $150.184,80$ & $162.618,40$ & $152.148,00$ & $(122.331,90)$ & $164.254,40$ & $71.002,40$ & $(64.867,40)$ & $144.377,00$ \\
\hline P\&D & 0,00 & 0,00 & 0,00 & 0,00 & $5.101,54$ & $7.999,12$ & $10.430,26$ & 0,00 & $12.311,98$ & $16.857,39$ & $15.241,56$ & $17.435,95$ \\
\hline TOTAL & $2.444 .888,54$ & 2.062.409,17 & $2.185 .459,89$ & \begin{tabular}{|l|}
$3.254 .047,21$ \\
\end{tabular} & $4.043 .670,08$ & $3.638 .068,97$ & $3.518 .090,52$ & 2.718.549,97 & $3.212 .732,08$ & $2.800 .659,12$ & $2.693 .581,72$ & $2.816 .756,21$ \\
\hline
\end{tabular}

Tabela 27 - Autoprodutor ligado à Rede Básica com Sazonalização da Energia assegurada “Moderada”- 2007 
$\mathrm{Na}$ tabela 28, a seguir, é apresentado o resumo comparativo com a somatória das referências de custos de cada cenário, para os anos de 2006 e 2007, e os valores totais para cada cenário estudado.

em $R \$$

\begin{tabular}{|l|r|r|r|r|}
\hline & \multicolumn{1}{|c|}{ Cenário 1 } & \multicolumn{1}{c|}{ Cenário 2 } & \multicolumn{1}{c|}{ Cenário 3 } & \multicolumn{1}{c|}{ Cenário 4 } \\
\hline Energia & $73.663 .326,00$ & $73.663 .326,00$ & $73.663 .326,00$ & $73.663 .326,00$ \\
\hline Demanda de Reserva & $91.388,31$ & 0,00 & 0,00 & 0,00 \\
\hline CCC/CDE/PROINFA & $589.035,94$ & 0,00 & $5.164 .507,12$ & $2.672 .714,90$ \\
\hline TUST - Carga & $1.186 .016,26$ & $5.554 .759,68$ & $5.554 .759,68$ & $5.554 .759,68$ \\
\hline TUST - Geração & $1.191 .230,57$ & $2.416 .440,00$ & $2.416 .440,00$ & $2.416 .440,00$ \\
\hline Comercialização de Energia & $(7.932 .331,43)$ & 0,00 & $(18.671 .277,30)$ & $(10.072 .614,64)$ \\
\hline ESS & $13.745,06$ & $360.875,89$ & $360.875,89$ & $360.875,89$ \\
\hline MRE & 0,00 & $(827.656,88)$ & $(822.644,91)$ & $(833.182,79)$ \\
\hline P\&D & $103.519,60$ & 0,00 & $255.512,93$ & $137.350,16$ \\
\hline TOTAL & $\mathbf{6 8 . 9 0 5 . 9 3 0 , 3 0}$ & $\mathbf{8 1 . 1 6 7 . 7 4 4 , 6 9}$ & $\mathbf{6 7 . 9 2 1 . 4 9 9 , 4 1}$ & $\mathbf{7 3 . 8 9 9 . 6 6 9 , 1 9}$ \\
\hline
\end{tabular}

Tabela 28 - Resumo Comparativo entre os Cenários.

No Gráfico 24 é apresentado o resumo mês a mês dos custos de cada cenário.

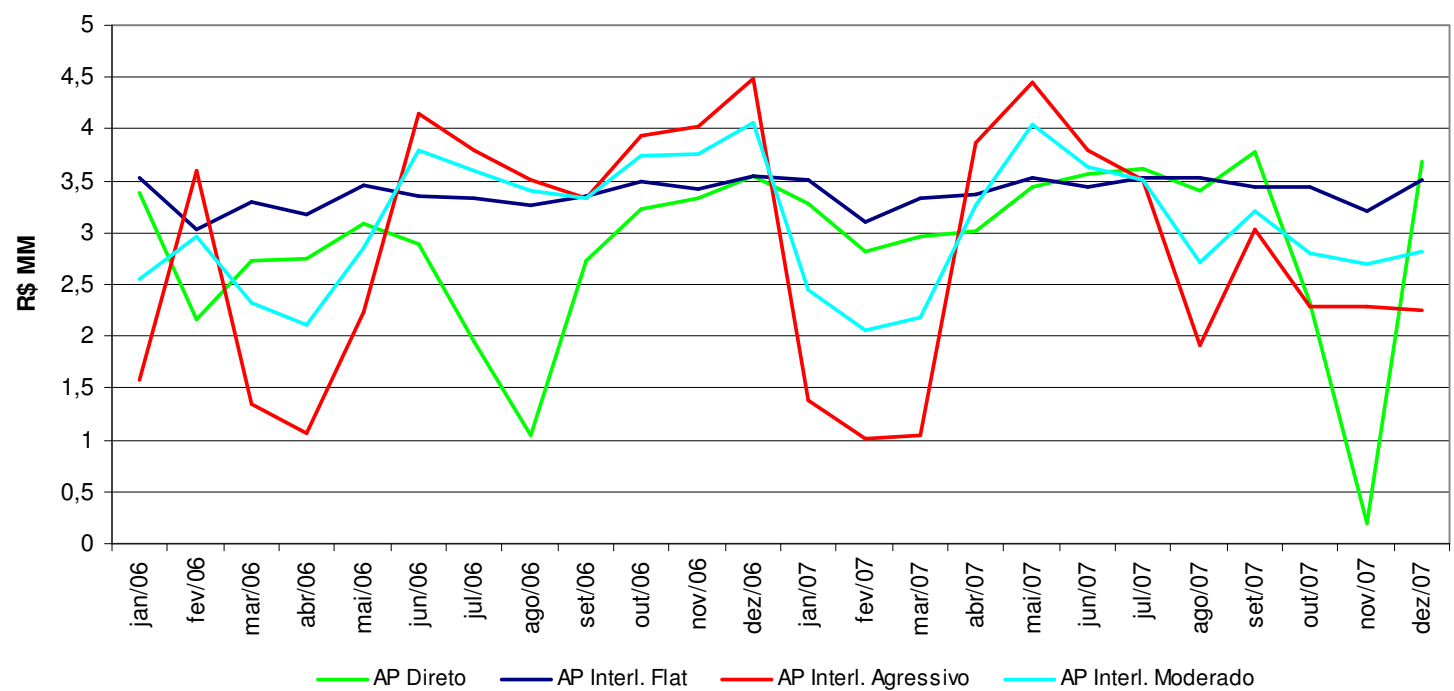

Gráfico 24 - Custos mensais de cada cenário estudado 


\section{CONCLUSÕES}

O objetivo do presente trabalho é estudar um caso, que aqui foi representado por uma fábrica de alumínio e pela UHE Piraju, e fazer uma análise econômica financeira comparativa da autoprodução direta ou conectada no SIN.

Os cálculos tiveram como base valores reais de geração, tarifas e PLD's, e as suposições de consumo da fábrica de alumínio, com carga igual a da energia assegurada, descontadas as perdas até o centro de gravidade, e as perdas deste até a fábrica, e também a energia assegurada sazonalizada, de acordo com os cenários 2,3 e 4.

De acordo com o resumo dos resultados obtidos na tabela 27, o Cenário 3, que teve uma sazonalização da energia assegurada, chamada de agressiva, e contando que a sazonalização, que é "ex-ante", acertou todos os meses de PLD's mais altos dos anos de 2006 e 2007, podemos verificar que esta sazonalização apresentou uma redução de $1,4 \%$ em relação ao caso base, que é a usina produzindo energia diretamente para a carga.

Analisando item a item os valores apresentados como despesa ou receita, podemos ver que:

- Energia - o custo para os 4 Cenários se manteve, pois a base de remuneração da usina não se altera;

- Demanda de Reserva - o custo somente é apresentado no Cenário 1, porque esta tarifa é específica para uma usina ligada diretamente à fábrica, e serve para proteção no caso de eventuais falhas;

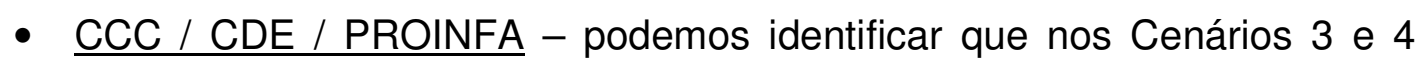
estes encargos são mais representativos, devido à sazonalização da energia assegurada propiciar uma maior compra de energia do sistema, onde esse encargo é incidido;

- TUST Carga - em comparação aos demais Cenários, o 1 apresenta baixo custo, pois a usina ligada à carga diminui a demanda necessária do 
sistema de transmissão e, conseqüentemente, é necessário firmar um menor contrato de CUST, com menores custos;

- TUST Geração - no Cenário 1, o custo deste encargo é refletido somente porque existe venda de energia ao mercado, isto é, geração superior a carga, mesmo assim este é menos representativo que nos demais cenários;

- Comercialização de Energia - devido à geração média da UHE Piraju ser superior a energia assegurada, no Cenário 1 a comercialização apresenta bons resultados, logicamente não comparados aos Cenários 3 e 4, que foram considerados um volume de energia comercializada superior nos meses onde o PLD tem seu maior valor, gerando uma grande receita e, conseqüentemente, reduzindo os custos de energia da fábrica;

- ESS - este encargo é cobrado proporcionalmente ao consumo de energia do sistema, em função deste ser mais representativo nos Cenários 2, 3 e 4, onde são conectados diretamente à Rede Básica;

- MRE - a geração junto à carga, como no Cenário 1, não dá direito à usina de participação no MRE, nos demais Cenários, devido à geração real ter sido superior a energia assegurada, nos anos de 2006 e 2007, este mecanismo gerou um crédito, reduzindo o custo final de energia da fábrica estudada;

- $\underline{\mathrm{P} \& \mathrm{D}}$ - é apresentada cobrança de encargo quando da comercialização de energia, como se apresenta nos cenários 1, 3 e 4. No Cenário 2, não existe este encargo, pois a diferença entre os valores de energia na fábrica e seu consumo é zero.

Ponderando os resultados apresentados nos diversos Cenários, verificamos que é mais viável à usina ligada diretamente à carga, pois a previsibilidade do 
mercado de preços de curto prazo é pequena, e dificilmente se acertaria com precisão os PLD’s registrados no ano seguinte ao da sazonalização.

Para um autoprodutor, o mais importante é estabilizar seus custos, como foi demonstrado no Cenário 2, e este demonstrou um custo de energia $17,8 \%$ superior em comparação ao Cenário 1.

Mesmo se comparado ao Cenário 3, que de forma moderada prevê a sazonalização nos maiores valores de PLD nos anos de 2006 e 2007, o Cenário 1 demonstra-se melhor.

Apesar de se tratar de um trabalho com cenários abrangendo apenas dois anos, é possível identificar que a melhor forma de se reduzir os custos com energia é a usina ligada diretamente à carga, e além do custo, outra vantagem é a minimização das perdas elétricas de transmissão.

Outro ponto importante que não foi considerado neste estudo e que incrementa custos às usinas ligadas no SIN, é a Resolução CNPE no 8/2007 que instaurou o despacho de usinas termelétricas fora da ordem de mérito, e que seus custos são pagos por todos os agentes do setor elétrico, sobre a parcela de consumo de energia na Rede Básica.

Entretanto, em contraponto à usina ligada diretamente à fábrica, tem-se que, como a geração no Brasil é basicamente de hidrelétricas, e o armazenamento de energia é estocástico, é possível que exista um melhor aproveitamento na geração física se esta usina for operada pelo ONS, que é o órgão competente para realização dos despachos e que procura otimizar o sistema.

Devido o Artigo 71 do Decreto nำ 5.163, de 30 de julho de 2004 impedir que a usina seja ligada diretamente a fábrica, se estes não estiverem no mesmo sítio, como alternativa, é sugerida a inclusão do parágrafo 9º, com a redação abaixo, visando que, se a economicidade comprovada do projeto for positiva, seja possível a ligação de uma usina diretamente ao consumo, sendo a usina separada da carga em qualquer distância. 
$\S 9^{\circ}$ Caso seja comprovada através do resultado positivo da aplicação da fórmula abaixo, será possível a construção de uma nova rede particular a qualquer distância entre a fonte geradora e a fonte de consumo, sem a necessidade de incorporação desta rede às concessionárias de transmissão ou distribuição.

$$
T P=\sum_{m 0 \sim m 60}\left(E_{R C}+C C C+C D E+P R O I N F A+P \& D+T U S T_{C}+T U S T_{G}+C E\right)
$$

Onde:

TP: $\quad$ índice de viabilidade do projeto;

$\sum_{m 0 \sim m 60}: \quad$ somatório dos custos mensais com início em $m_{0}$, que é o primeiro mês de janeiro, contados 5 anos civis anteriores ao cálculo do projeto;

$E_{R C}$ : encargo mensal pelo uso da reserva de capacidade, em $R \$$, calculado de acordo com a fórmula prevista no Art. 50 da Resolução Normativa ANEEL $n^{\circ}$ 304, de 04 de março de 2008;

CCC: $\quad$ valor total, em $R \$$, do encargo pago pelo consumidor na proporção da parcela de energia adquirida do sistema, multiplicada pelo valor da tarifa de CCC, vigente no ano de cálculo do projeto;

CDE: valor total, em $R \$$, do encargo pago pelo consumidor na proporção da parcela de energia adquirida do sistema, multiplicada pelo valor da tarifa de CDE, vigente no ano de cálculo do projeto;

PROINFA: valor total, em $R \$$, do encargo pago pelo consumidor na proporção da parcela de energia adquirida do sistema, multiplicada pelo valor da tarifa de PROINFA, vigente no ano de cálculo do projeto;

$P \& D: \quad$ valor total, em $R \$$, do encargo calculado conforme disposto na Lei $n^{\circ}$ 9.991, de 24 de julho de 2000; 
TUSTC: valor total, em $R \$$, do encargo cobrado pelo uso do sistema de transmissão referente à carga, ou caso for, pelo uso do sistema de distribuição, alterando-se a fórmula para TUSDc, calculada conforme a seguinte fórmula:

$$
T U S T_{C}=\left[C-\left(G E R_{M I N} * F S\right)\right]^{* T}
$$

Onde:

C: $\quad$ total da demanda da unidade de consumo;

GER MIN: menor geração, em MW médios, considerando a totalidade do histórico hidrológico da usina, não inferior a 30 anos;

FS: $\quad$ Fator de Segurança de 10\%;

T: $\quad$ valor da Tarifa de Uso do Sistema de Transmissão da carga, caso esta ainda não exista, calcular pelo método nodal, ou se esta estiver na rede de distribuição, tarifa da distribuidora (TUSD), local na data do projeto;

TUST $T_{G}$ : valor total, em $R$ \$, do encargo cobrado pelo uso do sistema de transmissão referente à geração, ou caso for, pelo uso do sistema de distribuição alterando-se a fórmula para $T U S D_{G}$, calculado conforme a seguinte fórmula:

$$
T U S T_{G}=\left(G E R_{M A X}-C\right) * F S * T_{G}
$$

Onde:

GER $R_{\text {MAX: }}$ maior geração, em MW médios, considerando a totalidade do histórico hidrológico da usina, não inferior a 30 anos;

C: $\quad$ total da demanda da unidade de consumo;

FS: $\quad$ Fator de Segurança de 10\%;

$T_{G}$ : valor da Tarifa de Uso do Sistema de Transmissão da geração, caso esta ainda não exista, calcular pelo método 
nodal, ou se esta estiver na rede de distribuição, tarifa de geração $\left(T U S D_{G}\right)$ da distribuidora local na data do projeto;

CE: pagamento ou recebimento referente à compra ou venda, respectivamente, de energia no mercado SPOT, calculado conforme a seguinte fórmula:

$$
C E=\left(E_{C}-E_{G E R}\right) * P_{R B} * P L D
$$

CE: $\quad$ valor total, em $R \$$, da receita ou encargo referente à venda ou compra de energia no mercado SPOT;

$E_{G E R}$ : energia média gerada no mês, em MW médios, considerando a totalidade do histórico hidrológico da usina, não inferior a 30 anos;

E $\quad$ : média do consumo de energia para o determinado mês $m$, da unidade de consumo;

$P_{R B}$ : $\quad$ Perdas da Rede Básica para levar o valor ao Centro de Gravidade do Submercado, considerando perdas de 3\%. Em caso de compra, adiciona-se $3 \%$, em caso de venda, retira-se 3\%;

PLD: $\quad$ valor do PLD do mês $m$ da venda ou compra da energia. Observadas as seguintes condições:

I - O proprietário da rede de transmissão será responsável por todos os custos de implantação, operação e manutenção;

II - No caso da viabilidade do projeto, e sendo emitida as devidas licenças ambientais da linha de transmissão, a ANEEL deliberará os devidos despachos referentes à faixa de servidão. 
A finalidade deste trabalho é contribuir aos Autoprodutores de Energia de que se possível for construir uma linha de transmissão ligando diretamente a usina à fábrica, e esta, sendo viável, o custo de energia em seu produto final é menor, podendo ter uma rentabilidade maior para seu negócio, e contribuir para a segurança do setor elétrico brasileiro, retirando carga do sistema.

Este trabalho também possibilita viabilizar aproveitamentos hidrelétricos atualmente inviáveis devido a seus custos de geração serem altos, podendo ser compensatório no caso da autoprodução se os resultados forem bons. 


\section{BIBLIOGRAFIA}

[1] MÁRTIRES, R. A. C. Balanço Mineral Brasileiro - 2001.

[2] Revista Alumínio - Ano I - 2007.

[3] Associação Brasileira do Alumínio, http://www.abal.org.br, Acesso em 20/05/2007.

[4] Anuário Estatístico ABAL 2006.

[5] CONSTANTINO, V.R.L., ARAKI, K., SILVA, D.O., OLIVEIRA, W. Preparação de compostos de alumínio a partir da bauxita: considerações sobre alguns aspectos envolvidos em um experimento didático. Quim. Nova, Vol. 25 (3), 490-498, 2002.

[6] Companhia Vale do Rio Doce, http://www.curd.com.br, Acesso em 20/05/2007.

[7] European Aluminium Association, http://www.eaa.net, Acesso em 23/05/2007.

[8] Companhia Brasileira de Alumínio, http://www.aluminiocba.com.br, Acesso em 23/05/2007.

[9] Fundamentos do Alumínio e suas Aplicações - ABAL - Edição de Janeiro de 2004.

[10] ALBRÁS Alumínio Brasileiro S.A. http://www.albras.net - acesso em 09/08/2007.

[11] Alcoa S.A., http://www.alcoa.com/brazil/pt/home.asp, acesso em 09/08/2007.

[12] ALUMAR Consórcio de Alumínio do Maranhão, http://www.alumar.com.br/ acessado em 13/08/07.

[13] CBA Companhia Brasileira de Alumínio, http://www.aluminiocba.com.br/ acesso em 13/08/2007. 
[14] Novelis Brasil Ltda., http://www.novelis.com.br - acesso em 13/08/2007.

[15] Companhia Vale do Rio Doce,

http://www.cvrd.com.br/files/2001_alum_aluvale.pdf. - acesso em 09/08/2007.

[16] Grupo Rede, http://www.gruporede.com.br/cemat/imp_release10.asp acesso em 01/01/2008.

[17] Centrais Elétricas do Norte do Brasil S.A - Eletronorte http://www.eln.gov.br - acesso em 01/01/2008.

[18] Eletrobrás

http://www.eletrobras.com.br/elb/portal/data/Pages/LUMIS79364694PTBRIE.htm - acesso em 01/01/2008.

[19] Relatório - Sistemas Elétricos Isolados - Período 2006 - 2016 - Análise do Mercado de Energia Elétrica - Eletrobrás - GTON.

[20] ANEEL Agência Nacional de Energia Elétrica, http://www.aneel.gov.br/area.cfm?idArea=443, Caderno Temático 3 ANEEL Energia Assegurada, acesso em 23/03/2008.

[21] BRASIL, CCEE Câmara de Comercialização de Energia Elétrica, http://www.ccee.org.br/cceeinterdsm/v/index.jsp?vgnextoid=2e09a5c1de88a 010VgnVCM100000aa01a8c0RCRD, acesso em 12/04/2008.

[22] ONS Operador Nacional do Sistema, http://www.ons.org.br/home/ , acesso em 12/04/2008.

[23] MEIRA FILHO, L. G. Mundo Negocia Pós-2012. [Depoimento a Giovana Girardi]. Jornal O Estado de São Paulo, São Paulo, 05 jun. 2008, p. X".

[24] BRASIL, Agência Nacional de Energia Elétrica - ANEEL, Resolução Normativa $n^{\circ}$ 304, de 04 de março de 2008, Altera dispositivos da Resolução no 371, de 29 de dezembro de 1999, que regulamenta a contratação e comercialização de reserva de capacidade por autoprodutor ou produtor 
independente para atendimento a unidade consumidora diretamente conectada às suas instalações de geração, e dá outras providências.

[25] BRASIL, Agência Nacional de Energia Elétrica - ANEEL, Resolução Normativa no 371, de 29 de dezembro de 1999, Regulamenta a contratação e comercialização de reserva de capacidade por autoprodutor ou produtor independente, para atendimento a unidade consumidora diretamente conectada às suas instalações de geração.

[26] BRASIL, Agência Nacional de Energia Elétrica - ANEEL, Resolução Homologatória no 671, de 24 de junho de 2008, Estabelece o valor das Tarifas de Uso do Sistema de Transmissão - TUST de energia elétrica, componentes do Sistema Interligado Nacional, fixa a tarifa de transporte da energia elétrica proveniente de Itaipu Binacional e estabelece os valores das Tarifas de Uso do Sistema de Distribuição - TUSD aplicáveis aos geradores que especifica.

[27] BRASIL, Agência Nacional de Energia Elétrica - ANEEL, Resolução Homologatória no 755, de 16 de dezembro de 2008, que estabelece a Tarifa de Energia de Otimização - TEO, com vigência a partir de $1^{\circ}$ de janeiro de 2009, para valorar a energia transferida entre as usinas participantes do Mecanismo de Realocação de Energia - MRE, no âmbito da Câmara de Comercialização de Energia Elétrica - CCEE.

[28] BRASIL, Presidência da República, Casa Civil, Subchefia para Assuntos Jurídicos, Lei no 9.991, de 24 de Julho de 2000, dispõe sobre realização de investimentos em pesquisa e desenvolvimento e em eficiência energética por parte das empresas concessionárias, permissionárias e autorizadas do setor de energia elétrica, e dá outras providências.

[29] BRASIL, Presidência da República, Casa Civil, Subchefia para Assuntos Jurídicos, Lei no 11.465, de 28 de Março de 2007, altera os incisos I e III do caput do art. $1^{\circ}$ da Lei no 9.991, de 24 de julho de 2000, prorrogando, até 31 de dezembro de 2010, a obrigação de as concessionárias e permissionárias 
de serviços públicos de distribuição de energia elétrica aplicarem, no mínimo, 0,50\% (cinqüenta centésimos por cento) de sua receita operacional líquida em programas de eficiência energética no uso final.

[30] BRASIL, Presidência da República, Silva; L.I.L. e Roussef; D.V., Decreto nำ 5.163, de 30 de Julho de 2004, Regulamenta a comercialização de energia elétrica, o processo de outorga de concessões e de autorizações de geração de energia elétrica, e dá outras providências. 